\title{
ZUSGS
}

Jins

Prepared in cooperation with the Bureau of Reclamation, Washington State Department of Ecology, and the
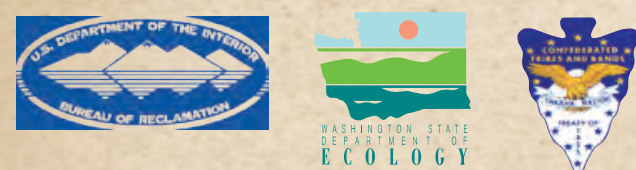
Yakama Nation

\section{Estimates of Ground-Water Pumpage from the Yakima River Basin Aquifer System, Washington, 1960-2000}

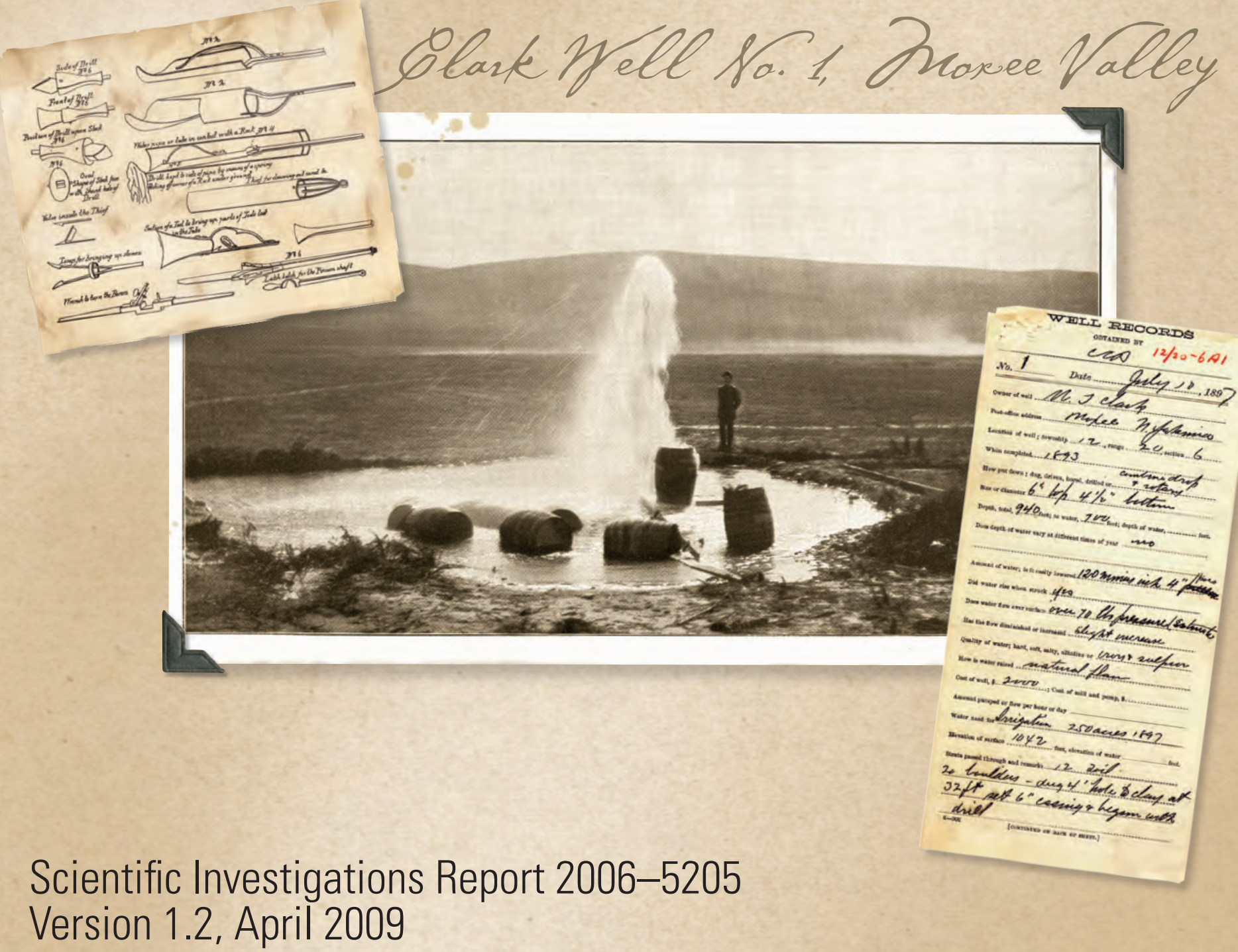

\section{U.S. Department of the Interior}

U.S. Geological Survey 
Cover: Photograph of Clark Well No. 1, located on the north side of the Moxee Valley in North Yakima, Washington. The well is located in township 12 north, range 20 east, section 6 . The well was drilled to a depth of 940 feet into an artesian zone of the Ellensburg Formation, and completed in 1897 at a cost of $\$ 2,000$. The original flow from the well was estimated at about 600 gallons per minute, and was used to irrigate 250 acres in 1900 and supplied water to 8 small ranches with an additional 47 acres of irrigation. (Photograph was taken by E.E. James in 1897, and was printed in 1901 in the U.S. Geological Survey Water-Supply and Irrigation Paper 55.) 


\section{Estimates of Ground-Water Pumpage from the Yakima River Basin Aquifer System, Washington, 1960-2000}

By J.J. Vaccaro and S.S. Sumioka

Prepared in cooperation with the Bureau of Reclamation, Washington State

Department of Ecology, and Yakama Nation

Scientific Investigations Report 2006-5205

Version 1.2, April 2009

U.S. Department of the Interior

U.S. Geological Survey 


\section{U.S. Department of the Interior \\ DIRK A. KEMPTHORNE, Secretary \\ U.S. Geological Survey \\ P. Patrick Leahy, Acting Director}

U.S. Geological Survey, Reston, Virginia: 2006

For product and ordering information:

World Wide Web: http://www.usgs.gov/pubprod

Telephone: 1-888-ASK-USGS

For more information on the USGS--the Federal source for science about the Earth, its natural and living resources, natural hazards, and the environment:

World Wide Web: http://www.usgs.gov

Telephone: 1-888-ASK-USGS

Any use of trade, product, or firm names is for descriptive purposes only and does not imply endorsement by the U.S. Government.

Suggested citation:

Vaccaro, J.J., and Sumioka, S.S., 2006, Estimates of ground-water pumpage from the Yakima River Basin aquifer system, Washington, 1960-2000: U.S. Geological Survey Scientific Investigations Report 2006-5205, 56 p. 


\section{Contents}

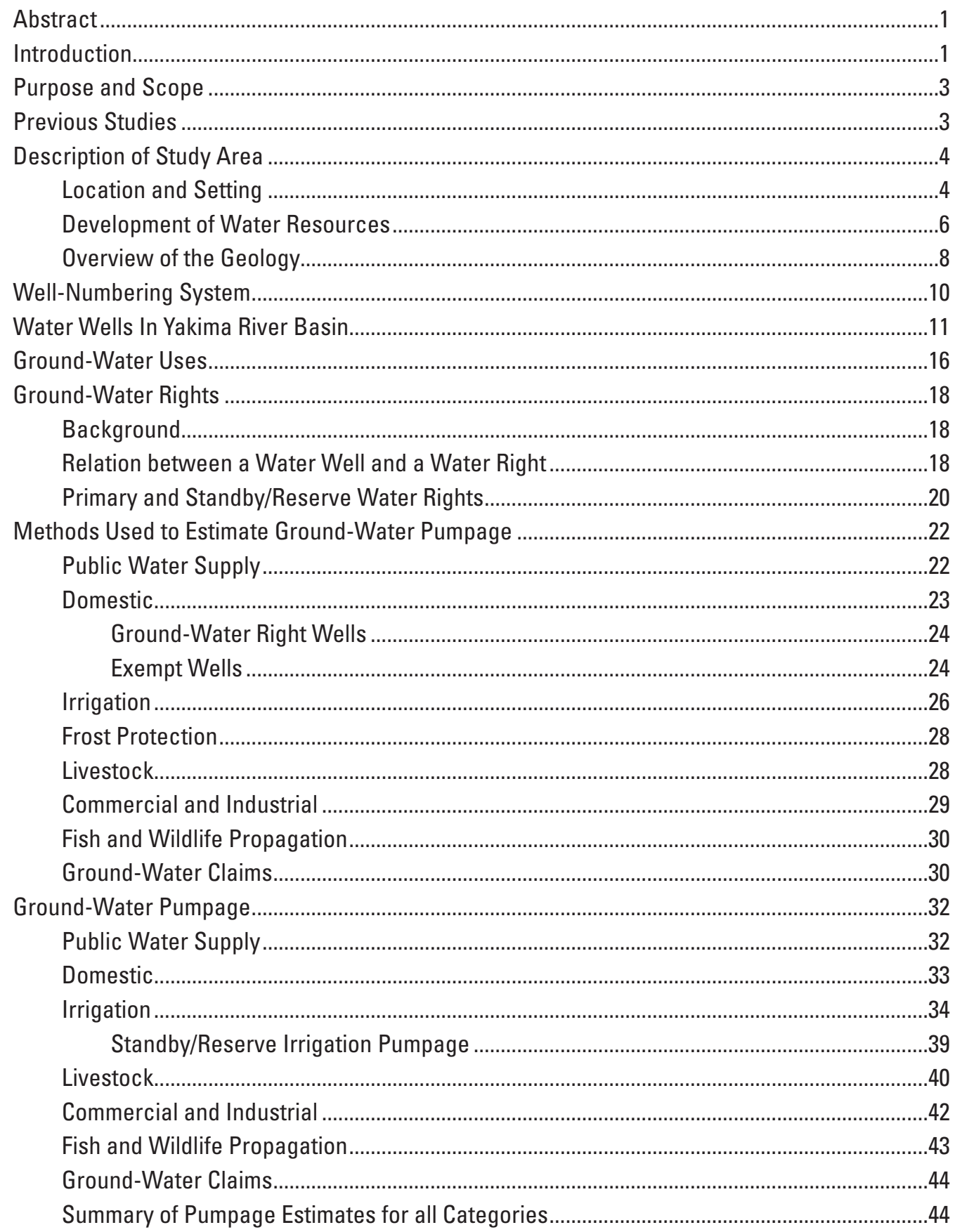




\section{Contents-Continued}

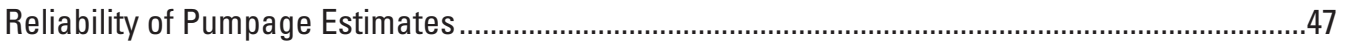

Public Water Supply and Domestic ...................................................................................

Irrigation

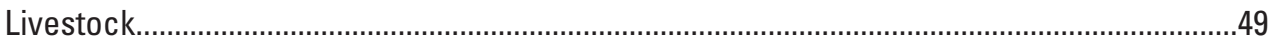

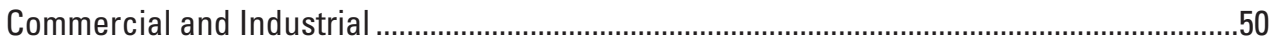

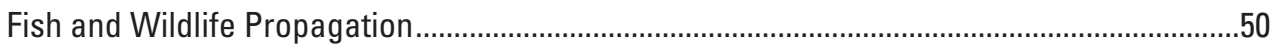

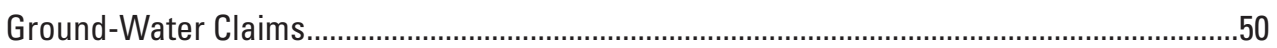

Comparison of Appropriated Ground-Water Rights and Estimated Pumpage ................................51

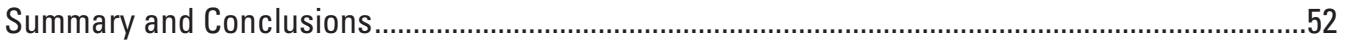

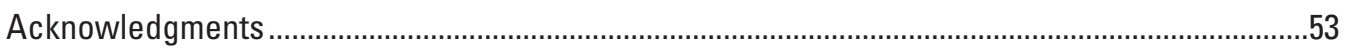

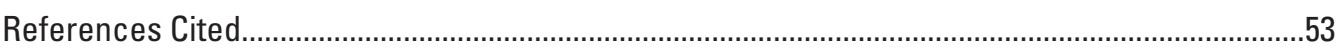

Appendix 1. List of Acronyms Used In Report........................................................................5

\section{Figures}

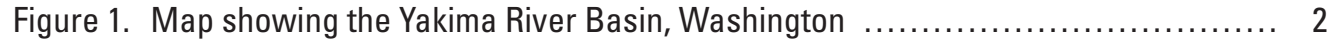

Figure 2. Map showing land use and land cover, Yakima River Basin, Washington, 1999 ................................................. 5

Figure 3. Schematic diagram showing selected tributaries, diversion canals, return flows, and stream-gaging stations, Yakima River Basin, Washington $\ldots \ldots \ldots \ldots .7$

Figure 4. Map showing simplified surficial geology, Yakima River Basin, Washington $\ldots . . .9$

Figure 5. Diagram showing well-numbering systems used in the State of Washington ...... 10

Figure 6. Photograph of front of original drillers' log for a 940-foot well drilled in 1897, Yakima River Basin, Washington

Figure 7. Photograph of original drillers' log for a 702-foot well drilled in 1896, Yakima River Basin, Washington

Figure 8. Graph showing number of wells completed each year 1890-2004, Yakima River Basin, Washington

Figure 9. Map showing distribution of depths of water wells, Yakima River Basin, Washington

Figure 10. Map showing location of surface-water irrigation districts, Yakima River Basin, Washington

Figure 11. Map showing distribution of census blocks and population, Yakima River Basin, Washington, 2000

Figure 12. Graph showing estimated annual pumpage for public water supply, Yakima River Basin, Washington, 1960-2000

Figure 13. Graph showing estimated monthly distribution of annual pumpage for public water supply, Yakima River Basin, Washington, 2000

Figure 14. Graph showing estimated annual pumpage for domestic use, Yakima River Basin, Washington, 1960-2000

Figure 15. Map showing distribution of estimated annual pumpage for domestic use, Yakima River Basin, Washington, 2000

Figure 16. Map showing distribution of estimated annual pumpage for irrigation, Yakima River Basin, Washington, 2000 


\section{Figures-Continued}

Figure 17. Graph showing estimated annual irrigation pumpage, Yakima River Basin, Washington, 1960-2000.

Figure 18. Graph showing generalized monthly distribution of irrigation pumpage during the irrigation season, Yakima River Basin, Washington, 2000

Figure 19. Graph showing estimated annual pumpage for livestock use, Yakima River Basin, Washington, 1960-2000

Figure 20. Map showing distribution of estimated annual pumpage for livestock and commercial and industrial uses, Yakima River Basin, Washington, 2000

Figure 21. Graph showing estimated annual pumpage for commercial and industrial uses, Yakima River Basin, Washington, 1960-2000

Figure 22. Graph showing estimated monthly distribution of annual pumpage for commercial and industrial uses, Yakima River Basin, Washington, 2000

Figure 23. Graph showing estimated monthly distribution of annual pumpage for fish and wildlife propagation, Yakima River Basin, Washington, 2000

Figure 24. Map showing distribution of estimated annual pumpage for ground-water claims, Yakima River Basin, Washington, 2000

Figure 25. Graph showing estimated annual pumpage, by pumpage category, Yakima River Basin, Washington, 1960-2000

\section{Tables}

Table 1. Relation between ground-water pumpage categories and water-right purpose of use codes in Washington State Department of Ecology's Water Rights Tracking System ....

Table 2. Estimated annual pumpage for public water supply, Yakima River Basin, Washington, 1960-2000

Table 3. Estimated annual pumpage for domestic use, Yakima River Basin, Washington, 1960-2000

Table 4. Estimated annual pumpage for irrigation water rights, Yakima River Basin, Washington, 2000

Table 5. Estimated irrigation pumpage, by primary and standby/reserve water rights, in 5-year increments, Yakima River Basin, Washington, 1960-2000

Table 6. Estimated annual pumpage for livestock use in 5-year increments, Yakima River Basin, Washington, 1960-2000

Table 7. Estimated annual pumpage for commercial and industrial uses in 5-year increments, Yakima River Basin, Washington, 1960-2000

Table 8. Estimated annual pumpage for fish and wildlife propagation in 5-year increments, Yakima River Basin, Washington, 1960-2000

Table 9. Summary of estimated annual pumpage, by pumpage category in 5-year increments, Yakima River Basin, Washington, 1960-2000

Table 10. Reliability of annual pumpage estimates, Yakima River Basin, Washington, 2000. 47

Table 11. Appropriated ground-water quantity and estimated pumpage for six categories of pumpage, Yakima River Basin, Washington, 2000 


\section{Conversion Factors and Datums}

Conversion Factors

\begin{tabular}{|c|c|c|}
\hline Multiply & By & To obtain \\
\hline inch (in.) & 2.54 & centimeter $(\mathrm{cm})$ \\
\hline inch (in.) & 25.4 & millimeter (mm) \\
\hline foot $(\mathrm{ft})$ & 0.3048 & meter $(\mathrm{m})$ \\
\hline mile (mi) & 1.609 & kilometer $(\mathrm{km})$ \\
\hline acre & 4,047 & square meter $\left(\mathrm{m}^{2}\right)$ \\
\hline square foot $\left(\mathrm{ft}^{2}\right)$ & 0.09290 & square meter $\left(\mathrm{m}^{2}\right)$ \\
\hline square inch $\left(\mathrm{in}^{2}\right)$ & 6.452 & square centimeter $\left(\mathrm{cm}^{2}\right)$ \\
\hline $\begin{array}{l}\text { section ( } 640 \text { acres or } 1 \text { square } \\
\text { mile) }\end{array}$ & 259.0 & square hectometer $\left(\mathrm{hm}^{2}\right)$ \\
\hline square mile $\left(\mathrm{mi}^{2}\right)$ & 2.590 & square kilometer $\left(\mathrm{km}^{2}\right)$ \\
\hline gallon (gal) & 3.785 & liter (L) \\
\hline gallon (gal) & 0.003785 & cubic meter $\left(\mathrm{m}^{3}\right)$ \\
\hline million gallons (Mgal) & 3,785 & cubic meter $\left(\mathrm{m}^{3}\right)$ \\
\hline billion gallons (Bgal) & $3,785,000$ & cubic meter $\left(\mathrm{m}^{3}\right)$ \\
\hline cubic foot $\left(\mathrm{ft}^{3}\right)$ & 0.02832 & cubic meter $\left(\mathrm{m}^{3}\right)$ \\
\hline acre-foot (acre-ft) & 1,233 & cubic meter $\left(\mathrm{m}^{3}\right)$ \\
\hline acre-foot/acre (acre-ft/acre) & 0.3048 & $\begin{array}{l}\text { cubic meter per square meter }\left(\mathrm{m}^{3} /\right. \\
\left.\mathrm{m}^{2}\right)\end{array}$ \\
\hline acre-foot per year (acre-ft/yr) & 1,233 & cubic meter per year $\left(\mathrm{m}^{3} / \mathrm{yr}\right)$ \\
\hline cubic foot per second $\left(\mathrm{ft}^{3} / \mathrm{s}\right)$ & 0.02832 & cubic meter per second $\left(\mathrm{m}^{3} / \mathrm{s}\right)$ \\
\hline gallon per minute (gal/min) & 0.06309 & liter per second $(\mathrm{L} / \mathrm{s})$ \\
\hline gallon per day (gal/d) & 0.003785 & cubic meter per day $\left(\mathrm{m}^{3} / \mathrm{d}\right)$ \\
\hline million gallons per day (Mgal/d) & 0.04381 & cubic meter per second $\left(\mathrm{m}^{3} / \mathrm{s}\right)$ \\
\hline
\end{tabular}

Datums

Vertical coordinate information is referenced to the North American Vertical Datum of 1988 (NAVD 88).

Horizontal coordinate information is referenced to the North American Datum of 1983 (NAD 83).

Altitude, as used in this report, refers to distance above the vertical datum. 


\title{
Estimates of Ground-Water Pumpage from the Yakima River Basin Aquifer System, Washington, 1960-2000
}

\author{
By J.J. Vaccaro and S.S. Sumioka
}

\section{Abstract}

Ground-water pumpage in the Yakima River Basin, Washington, was estimated for eight categories of use for 1960-2000 as part of an investigation to assess groundwater availability in the basin. Methods used, pumpage estimates, reliability of the estimates, and a comparison with appropriated quantities are described.

The eight categories of pumpage were public water supply, self-supplied domestic (exempt wells), irrigation, frost protection, livestock and dairy operations, industrial and commercial, fish and wildlife propagation, and ground-water claims. Pumpage estimates were based on methods that varied by the category and primarily represent pumpage for groundwater rights.

Washington State Department of Ecology's digital database has 2,874 active ground-water rights in the basin that can withdraw an annual quantity of about 529,231 acre-feet during dry years. Irrigation rights are for irrigation of about 129,570 acres. All but 220 of the rights were associated with well drillers' logs, allowing for a spatial representation of the pumpage. Five-hundred and sixty of the irrigation rights were estimated to be standby/reserve rights. During this study, another 30 rights were identified that were not in the digital database. These rights can withdraw an annual quantity of about 20,969 acre-feet; about 6,700 acre-feet of these rights are near but outside the basin.

In 1960, total annual pumpage in the basin, excluding standby/reserve pumpage, was about 115,776 acre-feet. By 2000, total annual pumpage was estimated to be 395,096 acre-feet, and excluding the standby/reserve rights, the total was 312,284 acre-feet. Irrigation accounts for about 60 percent of the pumpage, followed by public water supply at about 12 percent. The smallest category of pumpage was for livestock use with pumpage estimated to be 6,726 acre-feet. Total annual pumpage in 2000 was about 430 cubic feet per second, which is about 11 percent of the surface-water demand. Maximum pumpage is in July and August and during 2000, was about 100 cubic feet per second each month averaged over the Yakima River Basin aquifer system.
During 2000, non-standby/reserve pumpage associated with ground-water rights was estimated to total 253,454 acrefeet, or about 198,290 acre-feet less than the appropriated quantity. The unused part of the appropriated value is about equivalent to the irrigation pumpage for primary rights.

\section{Introduction}

Surface water in the Yakima River Basin, in south-central Washington (fig. 1), is under adjudication and the amount of surface water available for appropriation is unknown, but there are increasing demands for water for municipal, fisheries, agricultural, industrial, and recreational uses. These demands must be met by ground-water withdrawals and (or) by changes in the way water resources are allocated and used. On-going activities in the basin for enhancement of fisheries and obtaining additional water for agriculture may be affected by ground-water withdrawals and by rules implemented under the Endangered Species Act for salmonids that have been either listed or were proposed for listing in the late 1990s. An integrated understanding of the ground-water flow system and its relation to the surface-water resources is needed to implement most water-resources management strategies in the basin. To obtain this understanding, a study of the Yakima River Basin aquifer system began in June 2000. The study is a cooperative effort of the U.S. Geological Survey (USGS), Bureau of Reclamation (Reclamation), the Yakama Nation (YN), and the Washington State Department of Ecology (WaDOE).

The objectives of the study as a whole are to fully describe the ground-water flow system and its interaction with and relation to surface water, and provide baseline information for a management tool-a numerical model. The conceptual model of the flow system and the results of the study will be used to guide and support actions taken by management agencies with respect to ground-water availability and to provide information to other stakeholders and interested parties. The numerical model will be developed as an integrated tool to assess short-term to long-term management activities, including the testing of potential management strategies. 


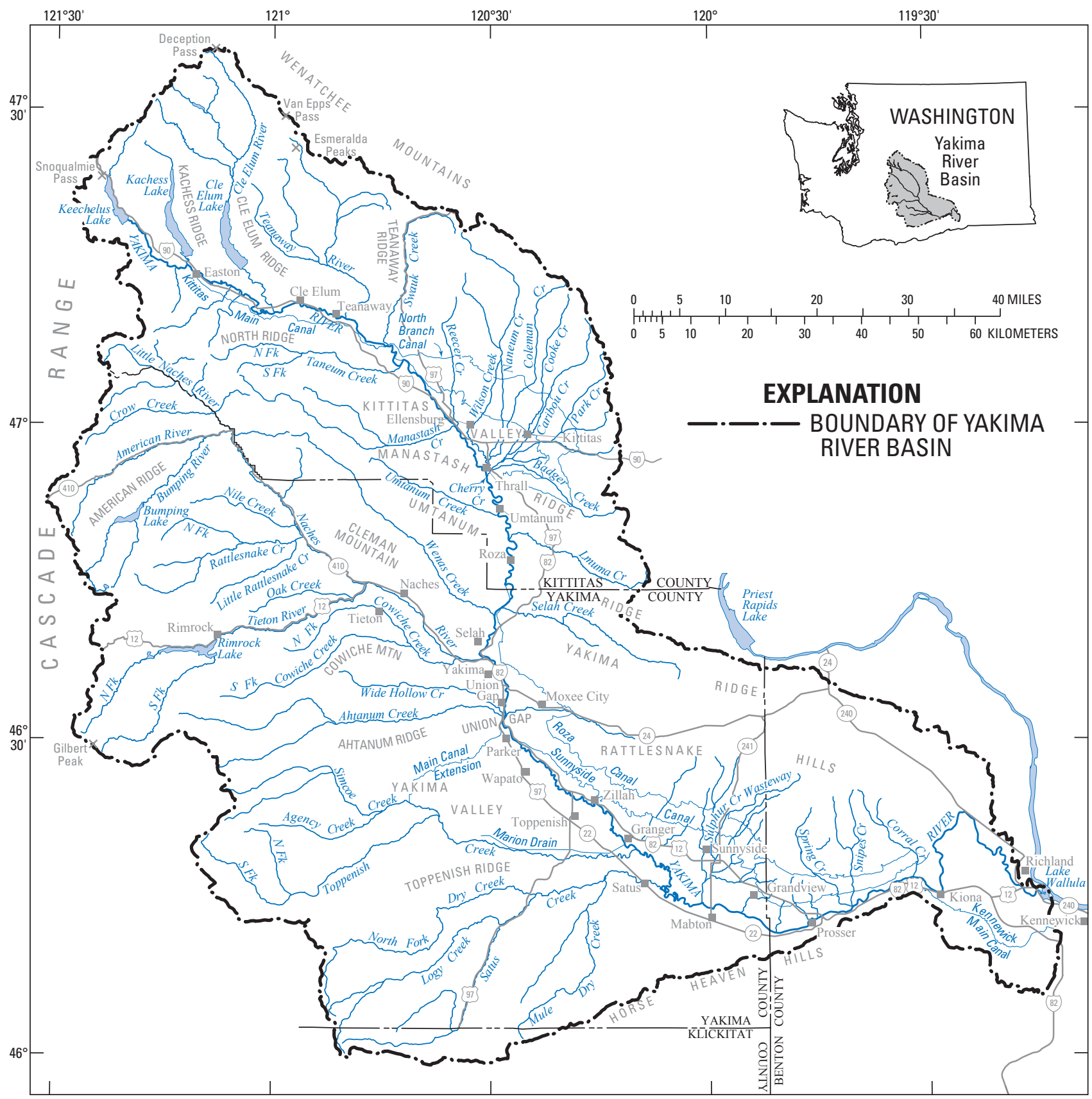

Figure 1. The Yakima River Basin, Washington. 
The study includes three phases. The first phase includes (1) project planning and coordination, (2) compiling, documenting, and assessing available data, and (3) initial data collection. The second phase consists of data collection to support the following Phase 2 work elements: (1) mapping of hydrogeologic units, (2) estimating ground-water pumpage, (3) developing estimates of ground-water recharge, (4) assessing ground water-surface water interchanges, and (5) constructing maps of ground-water levels. Together, these five elements provide the information needed to describe the ground-water flow system, the conceptual model, and provide the building blocks for the hydrogeologic framework. In the third phase, six structural basin models and one regional model of the ground-water flow system will be constructed in order to integrate the available information. The numerical models will be used to gain a further understanding of the flow system and its relation to surface water, and to test management strategies. The models will be developed and maintained in such a fashion that they will be available and open to others.

The results from selected work elements will be described in a series of reports. This report describes the estimates of ground-water pumpage from the Yakima River Basin aquifer system, a Phase 2 work element. The Introduction and Description of Study Area sections of this report are common to most reports for the other elements of the larger study.

\section{Purpose and Scope}

The purpose of this report is to provide estimates of annual ground-water pumpage for the Yakima River Basin for selected years from 1960 to 2000, and to compare the pumpage to appropriated ground-water rights. In this report, the term "pumpage" is synonymous with the term "withdrawal" and similar to the term "water use" used in other reports.

Pumpage is estimated and compared for eight categories of ground-water use: public water supply, self-supplied domestic, irrigation, frost protection, livestock and related operations, industrial and commercial, fish and wildlife propagation, and ground-water claims. A claim is a water-right document in which a claimant declares a claim for groundwater use and may be valid if it describes continual use starting prior to July 1945. Although most estimated pumpage for claims is for irrigation, claims are considered separate from the irrigation category. Pumpage estimates are based on information from public water systems, farms, various agencies of the State of Washington (Department of Health, Department of Ecology, and Department of Agriculture), census data, crop-type information, and measurements. Pumpage estimates are described or reported in units of acre-ft, Bgal, and Mgal/d, and unless otherwise stated, acre- $\mathrm{ft}$ and Bgal represent the volume pumped per year.

\section{Previous Studies}

Previous pumpage estimates were for the study area, part of the study area, and the entire three-county (Benton, Kittitas, and Yakima Counties) area that is larger than the study area. The estimates are not directly comparable but do provide information about the growth in pumpage and the range of estimates.

Kinnison and Sceva (1963) first estimated pumpage for the Yakima River Basin for 1953 and stated that the pumpage probably experienced "little change" by about 1961, although population in the three-county area increased from about 210,000 to about 228,000 during that time and ground-water rights increased from about 66,000 acre-ft to about 116,000 acre-ft (67 percent of which was for public water supply). Total pumpage was estimated at 51,665 acre-ft (16.8 Bgal) with irrigation accounting for 23,900 acre-ft (7.8 Bgal) or 46 percent of the total. Industrial pumpage was estimated at 14,600 acre-ft (4.8 Bgal), municipal supply at 7,800 acre-ft (2.5 Bgal), and domestic pumpage at 5,365 acre-ft (1.7 Bgal).

Laird and Walters (1967) estimated that total pumpage in 1965 was about 138,800 acre-ft (45.2 Bgal) for the threecounty area with irrigation accounting for 57 percent $(79,200$ acre-ft or $25.8 \mathrm{Bgal}$ ) of the total. Municipal pumpage was about 46,000 acre-ft (15 Bgal) and industrial was 13,470 acre-ft (4.4 Bgal). For 1970, Parker (1971) estimated the total pumpage, excluding self-supplied domestic pumpage, for the three counties as 132,233 acre- $\mathrm{ft}$ (43.1 Bgal). Irrigation accounted for 81,300 acre-ft (26.5 Bgal) or about 61 percent of the total. In 1970, the self-supplied industrial pumpage was estimated to be 10,440 acre-ft (3.4 Bgal) and the municipal pumpage was estimated to be 40,553 acre-ft (13.2 Bgal). Dion and Lum (1977) estimated municipal, industrial, and agricultural pumpage for 1975 by Washington State Water Resource Inventory Areas that compose the study area. Municipal, industrial, and agricultural use estimates for 1975 were 24,600 acre-ft (8.01 Bgal), 13,100 acre-ft (4.26 Bgal,) and 5,250 acre-ft (1.71 Bgal), respectively, and totaled 42,950 acre-ft (13.99 Bgal). Municipal estimates for 1965, 1970, and 1975 were for systems serving more than 100 people and the industrial estimates included only self-supplied ground water.

Ground-water pumpage was next estimated for most of the study area as part of the USGS's Regional Aquifer-System Analysis Program (Cline and Knadle, 1990; Cline and Collins, 1992, 1993). Estimates were for the part of the basin underlain by the Columbia River Basalt Group. Cline and Collins (1993) summarized estimates for the three counties and these estimates included some areas outside of the basin boundaries. Estimates were for selected years from 1945 through 1984. For 1984, pumpage (principally agricultural) was estimated to be about 83,280 acre-ft (27.1 Bgal); separate estimates for different uses were not made. 
In 2003, the Tri-County Watershed Resource Agency (TCWRA), representing the initiating governments involved in developing a watershed plan for the Yakima River Basin, published estimates of ground-water pumpage for 2000 (TriCounty Water Resource Agency, 2003). Methods used were based on water-rights documents, demographic data from the U.S. Census Bureau (U.S. Census Bureau, 2004), public water system data compiled by the Washington State Department of Health, and data collected for the largest municipal water suppliers in the basin. The TCWRA estimated total groundwater pumpage as 660,630 acre-ft (215 Bgal), which included standby/reserve rights (described in a later section). Most of this pumpage, about 529,567 acre-ft (172 Bgal), was irrigation pumpage. However, the irrigation pumpage estimate reported by TCWRA is the same as the reported total appropriated water for all permits and certificates. This total value is slightly greater than the value presented in this report due to apparent differences in the water-right database obtained from WaDOE. Excluding the large municipalities and self-supplied domestic pumpage, estimates were based on the maximum amount of water that can be used for each right. The amount actually used is typically less than the allowable amount. The TCWRA estimate for public water systems was about 74,700 acre-ft (24.3 Bgal).

Lane (2004) estimated withdrawals for 2000 for the entire three-county area. The estimated total withdrawal was 166,143 acre-ft (54 Bgal) of which 54 percent (about 90,000 acre-ft) was for irrigation. Total pumpage for domestic use was estimated to be 56,308 acre-ft (18.3 Bgal) and industrial withdrawals accounted for about 19,819 acre-ft (6.5 Bgal). Lane's total was only 25 percent of the total estimated by TCWRA for the study area in 2000.

\section{Description of Study Area}

The general location and setting of the study area, the development of water resources in the basin, and an overview of the geology are presented to provide a general background for understanding the study area.

\section{Location and Setting}

The Yakima River Basin aquifer system underlies about 6,200 $\mathrm{mi}^{2}$ in south-central Washington (fig. 1). The Yakima River Basin produces a mean annual unregulated streamflow (adjusted for regulation and without diversions or returns) of about 5,600 ft $3 / \mathrm{s}$ (about 4.1 million acre- $\mathrm{ft}$ ) and a regulated streamflow of about 3,600 $\mathrm{ft}^{3} / \mathrm{s}$ (about 2.6 million acre- $\mathrm{ft}$ ). The basin includes three Washington State Water Resource Inventory Areas (WRIA-numbers 37, 38, and 39), part of the Yakama Nation lands, and three ecoregions (Cascades, Eastern Cascades, and Columbia Basin [Omernik, 1987; Cuffney and others, 1997]). The basin includes parts of four counties (Klickitat, Kittitas, Yakima, and Benton). Almost all of Yakima County and more than 80 percent of Kittitas County lie within the basin, and about 50 percent of the Benton County is in the basin. Less than 1 percent of the basin lies in Klickitat County, principally in an unpopulated upland area.

The headwaters of the basin are on the upper, humid east slope of the Cascade Range, where the mean annual precipitation is more than $100 \mathrm{in}$. The basin terminates at the confluence of the Yakima and Columbia Rivers in the lowlying, arid part of the basin, which receives about 6 in. of precipitation per year. Altitudes in the basin range from 400 to nearly $8,000 \mathrm{ft}$. There are eight major rivers and numerous smaller streams tributary to the Yakima River (fig. 1); the largest tributary is the Naches River. Most of the precipitation in the basin falls during the winter months as snow in the mountains. The mean annual precipitation over the entire basin is about $27 \mathrm{in}$. (about 12,000 $\mathrm{ft}^{3} / \mathrm{s}$ or 8.7 million acre- $\mathrm{ft}$ ). The spatial pattern of mean annual precipitation resembles the pattern of the basin's highly variable topography. The difference between the mean annual precipitation and mean annual unregulated streamflow is $6,400 \mathrm{ft}^{3} / \mathrm{s}$ (about 4.6 million acre-ft) or about 53 percent of the precipitation is lost to evapotranspiration under natural conditions.

The basin is separated into several broad valleys by large east-west trending anticlinal ridges. The valley floors are flat and slope gently towards the Yakima River. Few perennial tributary streams traverse these valleys. Most of the population and economic activity occurs in these valleys.

Agriculture is the principal economic activity in the basin. The average annual surface-water demand met by the Reclamation project is about 2.5 million acre- $\mathrm{ft}$; there is about 336,000 acre-ft of additional demand in the lower river basin that is separate from the demand met by the project. Additional surface-water demand that is not met by Reclamation occurs in smaller tributaries and on the large rivers; this demand is based on State appropriated water. More than 95 percent of the demand is for irrigation of about 500,000 acres in the low-lying semiarid to arid parts of the basin (fig. 2). The demand is partially met by storage of nearly 


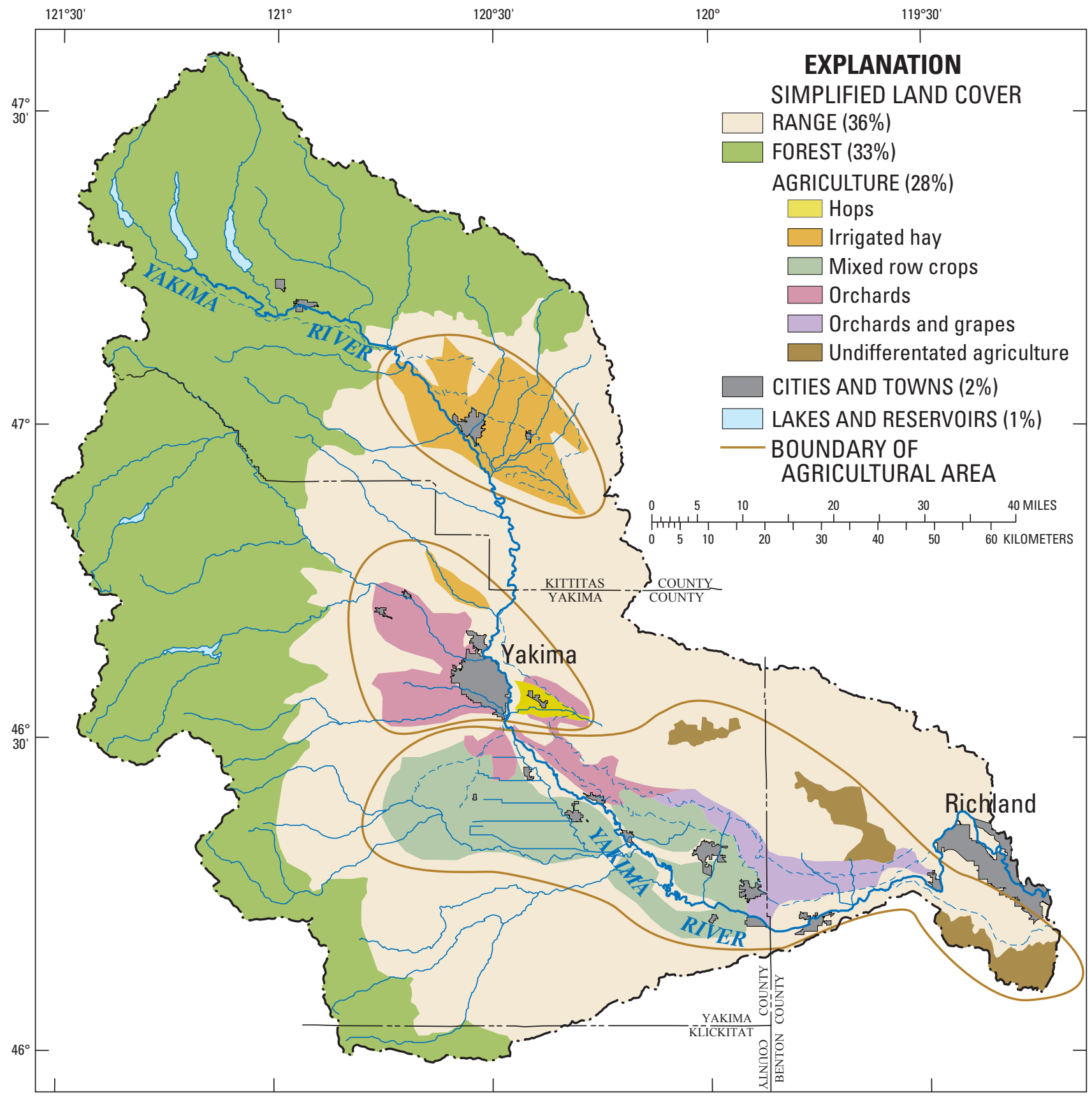

Figure 2. Land use and land cover, Yakima River Basin, Washington, 1999. 
1.1 million acre-ft of water in five Reclamation reservoirs. The major management point for Reclamation is at the Yakima River near Parker streamflow gaging station. Just upstream of this site, at Union Gap, is the location that is considered the dividing line between the upper (mean annual precipitation of 7 to 125 in.) and lower (mean annual precipitation of 6 to 45 in.) parts of the Yakima River Basin. About 45 percent of the water diverted for irrigation is eventually returned to the river system as surface-water inflows and ground-water discharge, but at varying time-lags (Bureau of Reclamation, 1999). During the low-flow period, these return flows, on average, account for about 75 percent of the streamflow below the Yakima River near Parker streamflow gaging station. Much of the surface-water demand in the basin below Parker is met by these return flows and not by the release of water from the reservoirs. As a result of water use in the basin, the difference between mean annual unregulated and regulated streamflow in the basin is about $2,000 \mathrm{ft}^{3} / \mathrm{s}$, suggesting that some 1.4 million acre-ft of water, or about 17 percent of the precipitation in the basin, is consumptively used principally by irrigated crops via evapotranspiration.

\section{Development of Water Resources}

Missionaries arrived in the basin in 1848 and established a mission in 1852 on Atanum (now Ahtanum) Creek. They were some of the first non-Indian settlers to use irrigation on a small scale. Miners and cattlemen immigrated to the basin in the 1850s and 1860s, which resulted in a new demand for water. With increased settlement in the mid-1860s, irrigation of the fertile valley bottoms began and the outlying areas were extensively used for stock raising. One of the first known non-Indian irrigation ditches was constructed in 1867 and diverted water from the Naches River (Parker and Storey, 1913; Flaherty, 1975). Private companies later delivered water through canal systems built between 1880 and 1904 for the irrigation of large areas. The development of irrigated agriculture was made more attractive by the construction of the Northern Pacific Railway that reached Yakima in December 1884, which provided a means to transport agricultural goods to markets; two years later, the completion of the railway to the coast provided new and easily accessible markets for agricultural products. The State of Washington was created in 1889, spurring further growth in the basin, especially because the cities of Ellensburg and Yakima were in contention for being the state capital. By 1902 there were about 120,000 acres under mostly surface-water irrigation in the basin (Parker and Storey, 1913; Bureau of Reclamation, 1999).
The Federal Reclamation Act was enacted in 1902 to enable the construction of Federal water projects in the western United States in order to expand the development of the West. In 1905, the Washington State Legislature passed the Reclamation Enabling Act and the Yakima Federal Reclamation Project was authorized to construct facilities to irrigate about 500,000 acres. As part of the 1905 authorization and extensions, all forms of further appropriation of unappropriated water in the basin were withdrawn (Parker and Storey, 1913). Six dams were constructed as part of the Yakima Project: Bumping Dam in 1910, Kachess Dam in 1912, Clear Creek Dam in 1914, Keechelus Dam in 1917, Tieton Dam (Rimrock Lake) in 1925, and Cle Elum Dam in 1933. The construction of the dams and other irrigation facilities resulted in an extremely complicated surface-water system (fig. 3). These Federal reservoirs provide water storage to meet irrigation requirements of the major irrigation districts at the time of year when the natural streamflow from unregulated streams can no longer meet demands; this time is referred to as the 'storage control' date. Several of the reservoirs also provide instream flows during the winter for the incubation of salmon eggs in the salmon redds (gravel spawning nests).

Legal challenges to water rights resulted in the 1945 Consent Decree (U.S. District Court, 1945) that established the framework of how the Reclamation operates the Yakima Project to meet the water demands. The Decree determined two classes of rights - nonproratable and proratable. When the total water supply available (TWSA-defined as current available storage in the reservoirs, estimates of unregulated flow, and other sources that are principally return flows) is not sufficient to meet both classes of rights, the proratable (junior) rights are decreased according to the quantity of water available defined by the TWSA. This legally mandated method generally performs well in most years, but is dependent on the accuracy of the TWSA estimate. In some years, for example 1977, problems have arisen because of errors in the TWSA estimate (Kratz, 1978; Glantz, 1982). System management also accounts for defined instream flows at selected target points on the river, and for suggested changes in storage releases recommended by the Systems Operations Advisory Committee (SOAC) — the advisory board of fishery biologists representing the different stakeholders (Systems Operations Advisory Committee, 1999).

The drilling of numerous wells for irrigation was spurred by new (post 1945) well-drilling technologies, legal rulings, and the onset of a multi-year dry period in 1977 (Vaccaro, 1995). Population growth in the basin was, and still is, the 

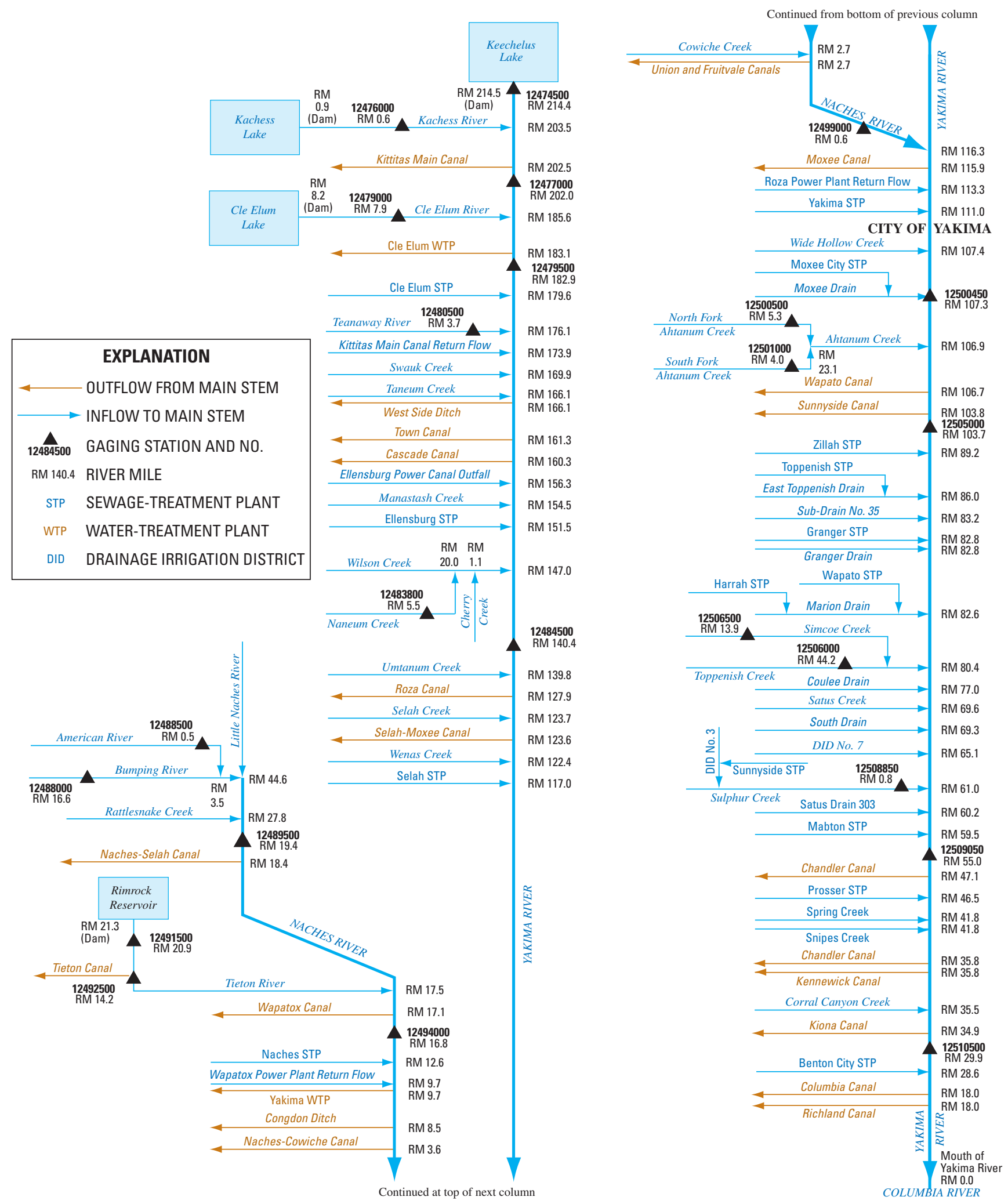

Figure 3. Selected tributaries, diversion canals, return flows, and stream-gaging stations, Yakima River Basin, Washington. 
driving force behind the increased drilling of shallow domestic wells and deeper public water supply wells. Currently, there are more than 20,000 wells in the basin. More than 70 percent of these wells are shallow, 10-250-ft deep, domestic wells. Based on the digital water-rights database provided by WaDOE (R. Dixon, written commun., 2001) and other information there are at least 2,874 active ground-water rights associated with the wells in the basin that can withdraw an annual quantity of about 529,231 acre-ft during dry years. The irrigation rights are for the irrigation of about 129,570 acres. There are about 16,600 ground-water claims in the basin; these claims are for some 270,000 acre-ft of ground water (J. Kirk, written commun., Washington State Department of Ecology, 1998). 'A water right claim is a statement of claim to water use that began before the state Water Codes were adopted, and is not covered by a water right permit or certificate. A water right claim does not establish a water right, but only provides documentation of one if it legally exists. Ultimately, the validity of claimed water rights would be determined through general water right adjudications' (Washington State Department of Ecology, 1998). A ground-water claim means a user claims that they were using ground water continuously, prior to 1945 when the State legislature enacted the Ground Water Code, for a particular use.

\section{Overview of the Geology}

The Columbia Plateau has been informally divided into three physiographic subprovinces (Meyers and Price, 1979). The western margin of the Columbia Plateau contains the Yakima Fold Belt subprovince and includes the Yakima River Basin. The Yakima Fold Belt is a highly folded and faulted region and within the study area part, it is underlain by various consolidated rocks, ranging in age from Precambrian to Tertiary, and unconsolidated materials and volcanic rocks of Quaternary age (fig. 4). In the Yakima River Basin, the headwater areas in the Cascade Range include metamorphic, sedimentary, and intrusive and extrusive igneous rocks. The central, eastern, and southwestern parts of the basin are composed of basalt lava flows of the Columbia River
Basalt Group (CRBG) with some intercalated sediments that are discontinuous and weakly consolidated. The lowlands are underlain by unconsolidated and weakly consolidated valley-fill composed of glacial, glacio-fluvial, lacustrine, and alluvium deposits that in places exceed a 1,000 ft in thickness (Drost and others, 1990). Wind-blown deposits, called loess, occur locally along the lower valley.

Valley-fill deposits and basalt lava flows are important for ground-water occurrence in the study area. The basalt consists of a series of flows erupted during various stages of the Miocene Age, ranging from 17 to 6 million years ago. Basalt erupted from fissures from the eastern part of the Columbia Plateau and individual flows range in thickness from a few feet to more than $100 \mathrm{ft}$. The total thickness in the central part of the plateau is estimated to be greater than 10,000 ft (Drost and others, 1990) with a maximum thickness of more than $8,000 \mathrm{ft}$ in the study area. Unlike most of the Columbia Plateau, the CRBG in the Yakima Fold Belt is underlain by sedimentary rocks. The valley-fill deposits were eroded from the Cascade Range and from the east-west-trending anticlinal ridges that were formed from the buckling of the basalt sequence during mid- to late-Miocene time. Much of these deposits are part of the Ellensburg Formation. This formation underlies, intercalates, and overlies the basalts along the western edge, and composes most of the thickness of the unconsolidated deposits (informally called the overburden; Drost and others, 1990) in the basinal areas. The basins are narrow to large open synclinal valleys intervening between the numerous anticlinal ridges.

The deposition of a thick, upper sequence of sand, gravel, and some fine-grained material is the result of erosion by glacial ice and transport by meltwater streams. Damming of large lakes by glacial ice during the Pleistocene epoch resulted in the deposition of silt and clay beds in parts of the uplands. When the lakes drained, the fine sediments were exposed and subsequently eroded by wind and deposited over the lower, eastern parts of the study area. Thus, the unconsolidated materials in the basinal areas that are abutting and interbedded with the basalts range from Miocene to Holocene in age. 


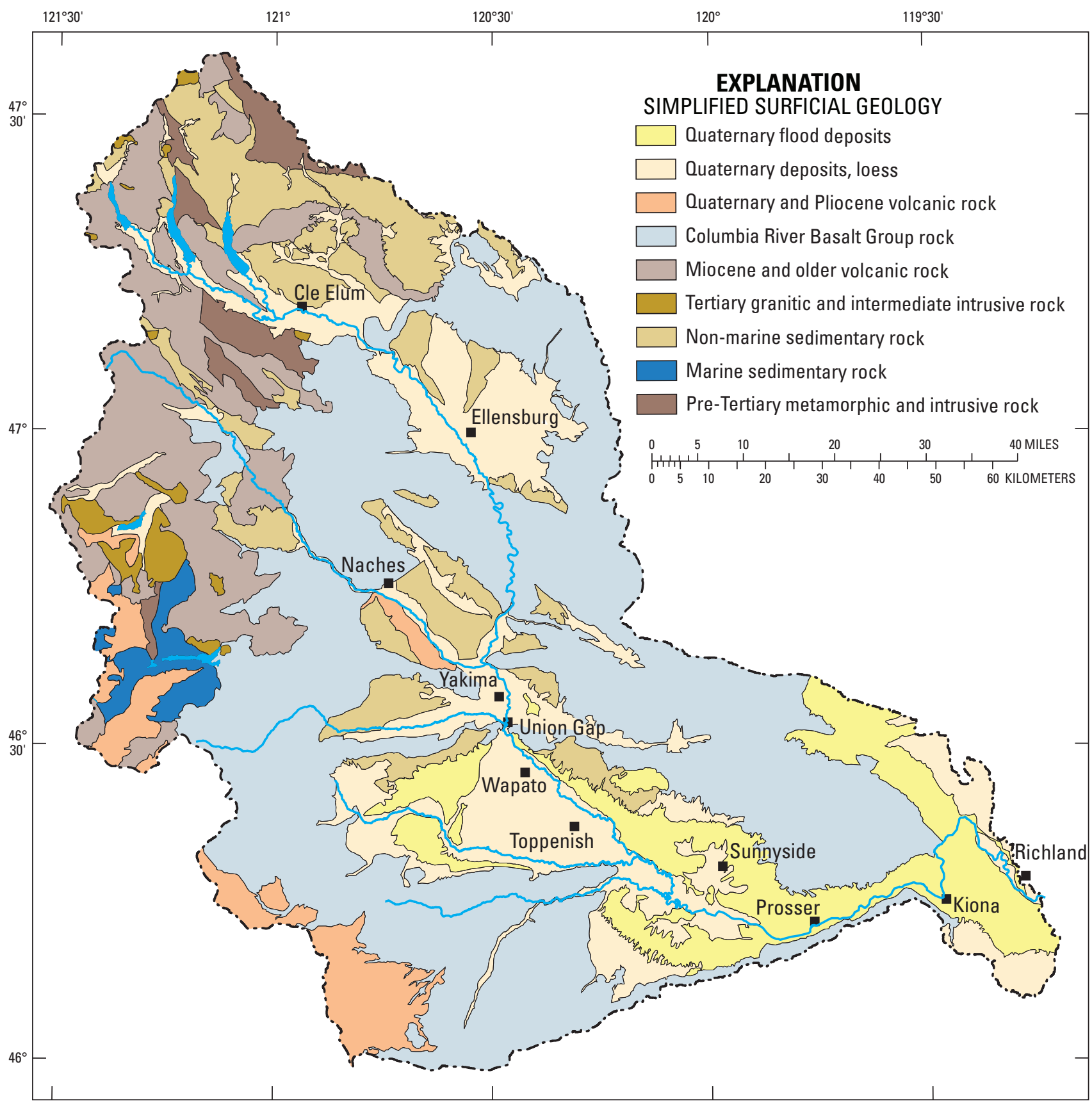

Figure 4. Simplified surficial geology, Yakima River Basin, Washington. 


\section{Well-Numbering System}

The USGS assigns numbers to wells and springs in Washington that identify their location in a township, range, and section. Well number 20N/15E-26N01 indicates, successively, the township (T.20 N.) and the range (R.15 E.) north and east of the Willamette baseline and meridian (fig. 5). The first number following the hyphen indicates the section (26) within the township and the letter following the section number $(\mathrm{N})$ gives the 40 -acre subdivision on the section, as shown above. The number (01) following the letter is the sequence number of the well within the 40-acre subdivision. An ' $\mathrm{S}$ ' following the sequence number indicates that the site is a spring, a 'D1' after the sequence number indicates that the original reported depth of the well has been changed once and successive numbers indicate the number of changes in the well depth. An ' $R$ ' following the sequence number indicates the well has been reconditioned. A 'P1' or an 'A' after the sequence number indicates a group of nested piezometers, with successive numbers or letters assigned to each piezometer in the group.

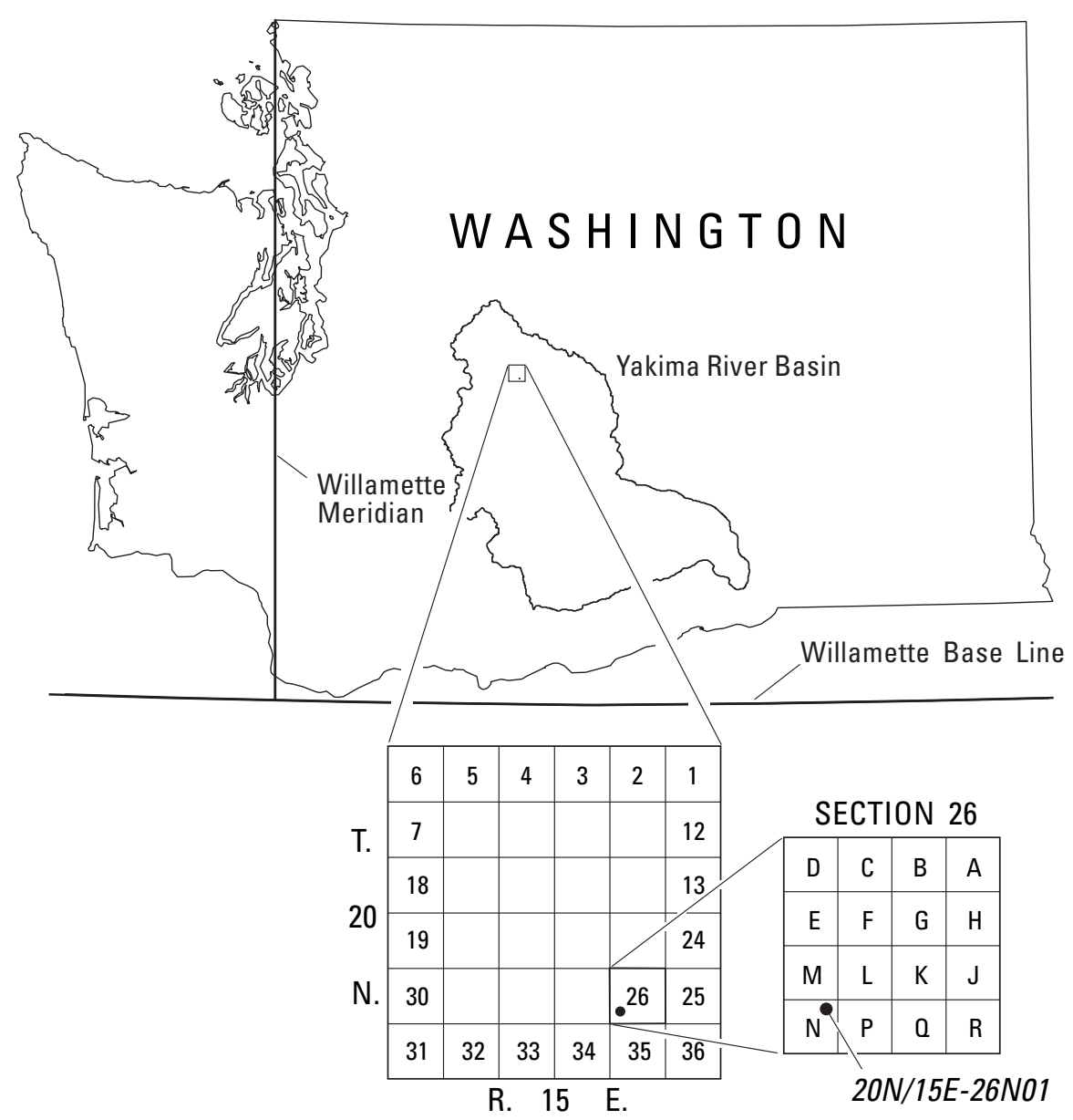

Figure 5. Well-numbering systems used in the State of Washington. 


\section{Water Wells In Yakima River Basin}

There is a long history of constructing water wells in the basin concurrent with the development of the surface-water systems. Continual growth in the basin in the late 1880s resulted in more households in the river valleys without access to surface-water supply from streams. This growth led to digging shallow, 10-40-ft deep, wells that were generally completed in the alluvial deposits. Continued development of new drilling methods for water wells (Carlston, 1943), especially deep wells, resulted in the search for artesian water throughout many parts of the United States (Darton, 1902). This search began in earnest in the basin in the 1890s. A 700-ft deep well was drilled to basalt in the Kittitas basin in the early 1890s, but the water level was $48 \mathrm{ft}$ below land surface and the well was abandoned (Russell, 1897). In 1890, a well was drilled to 400-ft depth in the Wenas basin with water at $152 \mathrm{ft}$ and another well was drilled in the same year to 270-ft depth in the Selah basin at Rye Grass Flat (Smith, 1901).

During 1891-1901, 24 wells were drilled in the Moxee area and ranged in depth from 225 to $1,000 \mathrm{ft}$; all these wells were artesian wells and were capable of irrigating about 1,000 acres (Smith, 1901). Several of these wells are still in use as of 2005. The front cover of this report shows a picture of the 'Clark Well No. 1' from Smith's early report (Smith, 1901) and the front of the original drillers' log from USGS files is shown in figure 6 . This well irrigated 250 acres in 1900 and supplied water to an additional 47 acres for 8 small ranches (Smith, 1901). Another drillers' log for the 702-ft deep Haines well (the driller of many of these wells) is shown in figure 7; this well was used for irrigating 85 acres (Smith, 1901).

Population growth after 1900 and lack of unappropriated irrigation water from smaller streams during the low-flow season resulted in a need for additional water supply; therefore, the number of dug or drilled wells continued to increase. Based on information from the USGS National Water
Information System (NWIS) and information compiled as part of this investigation, at least 200 wells were constructed by 1910 . The increase in the number of wells generally follows population growth in the basin. The number of wells constructed each year records were available, starting in 1890, is shown in figure 8 . The compilation of well information for this investigation was mostly completed by 2002 , so the number of wells for 2002-04 is not fully represented. By 2004, digital files compiled as part of this study indicated that at least 22,000 water wells were in the basin and more than 60 percent were in Yakima County. This estimate undoubtedly is low because, except for water-right wells, drillers' logs were not generally available for the first half of the $20^{\text {th }}$ century and were not commonly recorded with the State until after 1970. Digital files and information compiled for this study to estimate ground-water pumpage indicate that on the order of 45,000 water wells currently are in the basin.

As the number of wells increased, depths also increased because households and croplands irrigated with ground water were established farther from streams and river valleys. Compiled information for the three county area indicates that 90 percent of the wells are less than $456-\mathrm{ft}$ deep, 70 percent are less than 240-ft deep, and 50 percent are less than 151-ft deep. Well-depth percentiles are similar for each of the three counties. The spatial distribution of about 21,000 wells, shown by well depth, indicates most are in or near the low-lying basins (fig. 9); well locations and depths are from digital files developed as part of this study. The distribution and depths of wells on figure 9 is not for detailed analysis because locations of many wells were determined from information on drillers' logs that could be incorrect. About 55 percent of the wells are finished in the basin-fill deposits and the remaining wells are finished in bedrock materials, primarily basalt, based on well depth and the altitude of the top of bedrock maps constructed as part of this investigation (Jones and others, 2006). 


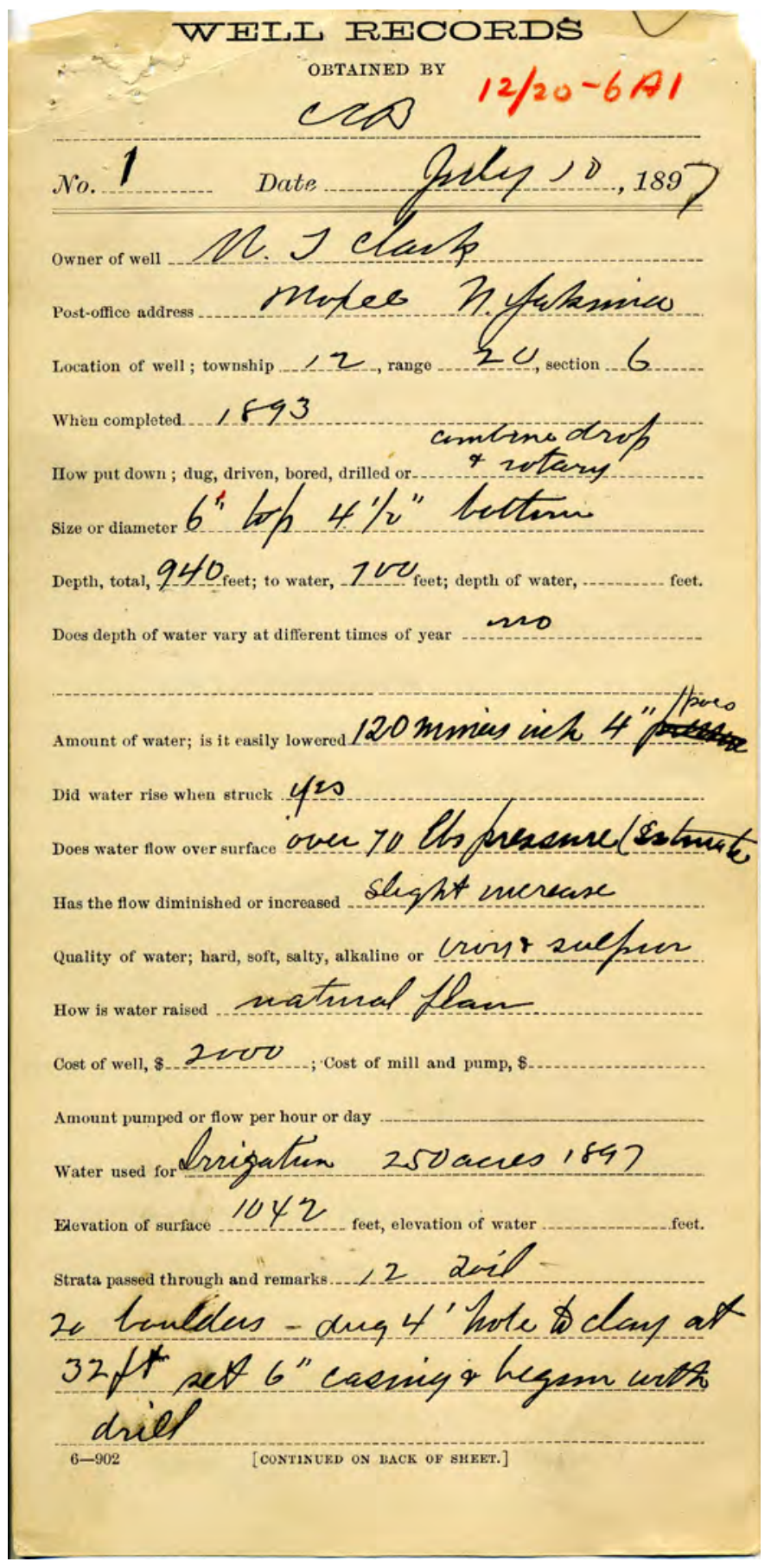

Figure 6. Front of original drillers' log for a 940-foot well drilled in 1897, Yakima River Basin, Washington. 

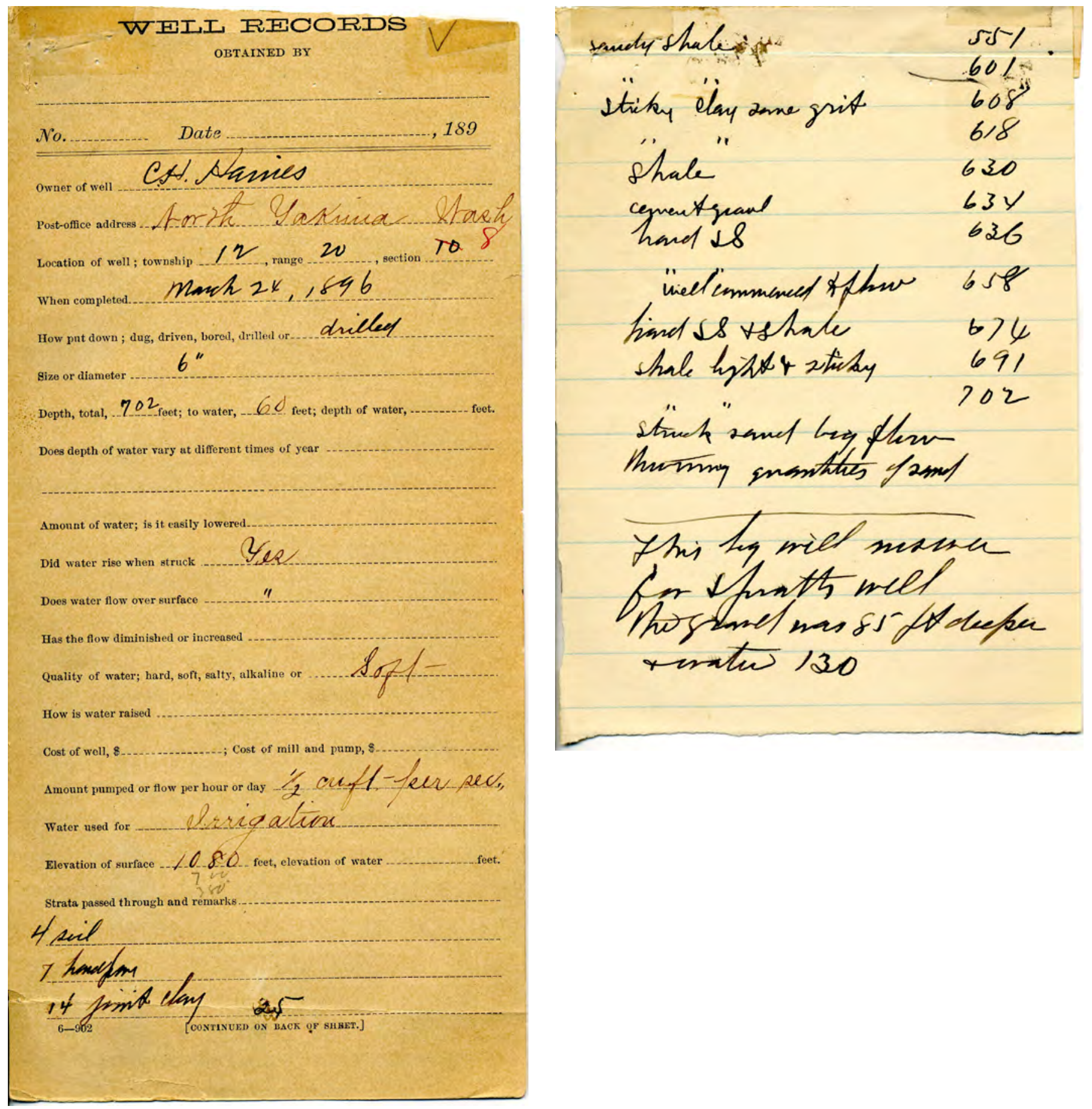

Figure 7. Original drillers' log for a 702-foot well drilled in 1896, Yakima River Basin, Washington. 


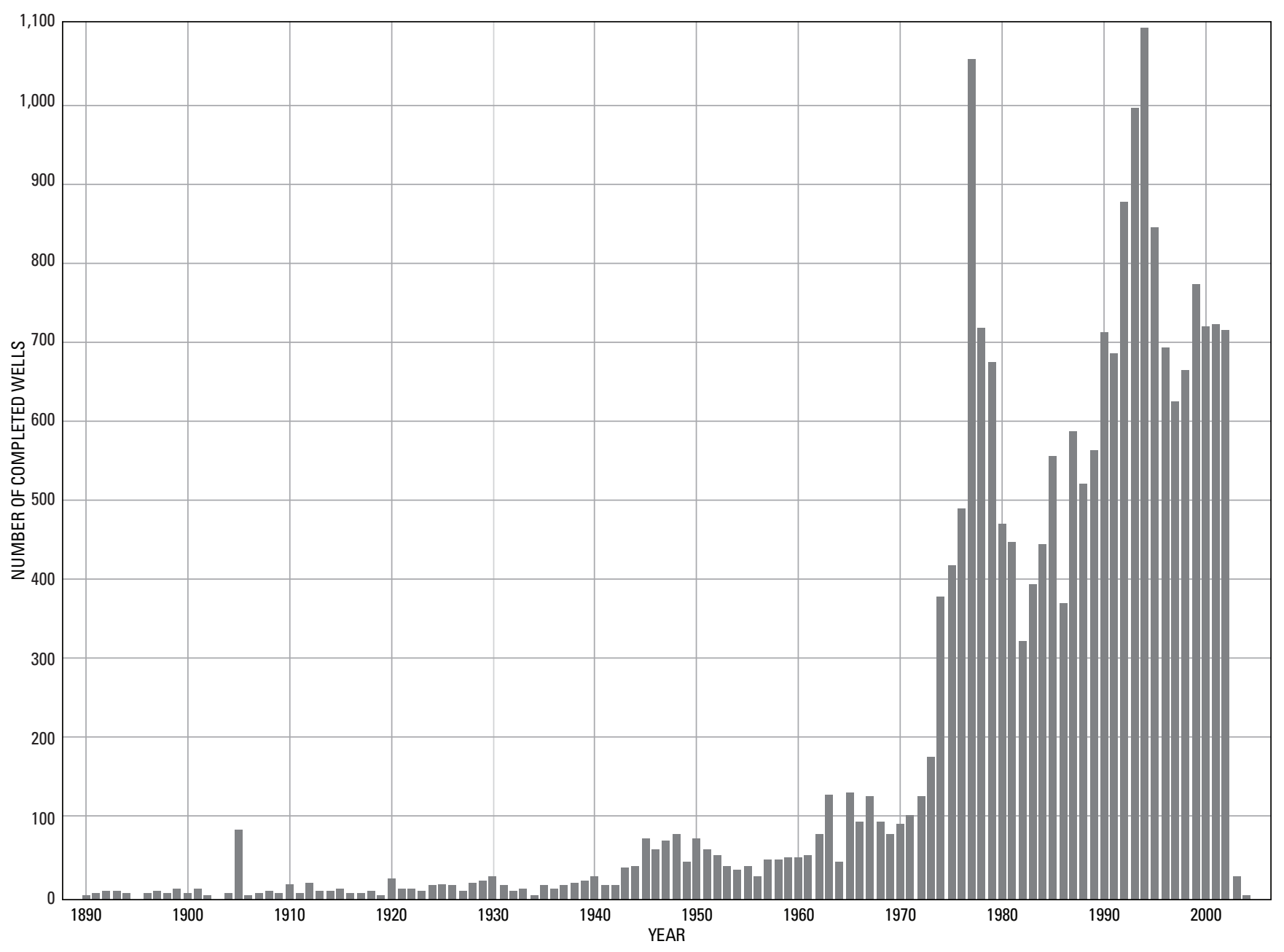

Figure 8. Number of wells completed each year 1890-2004, Yakima River Basin, Washington. 


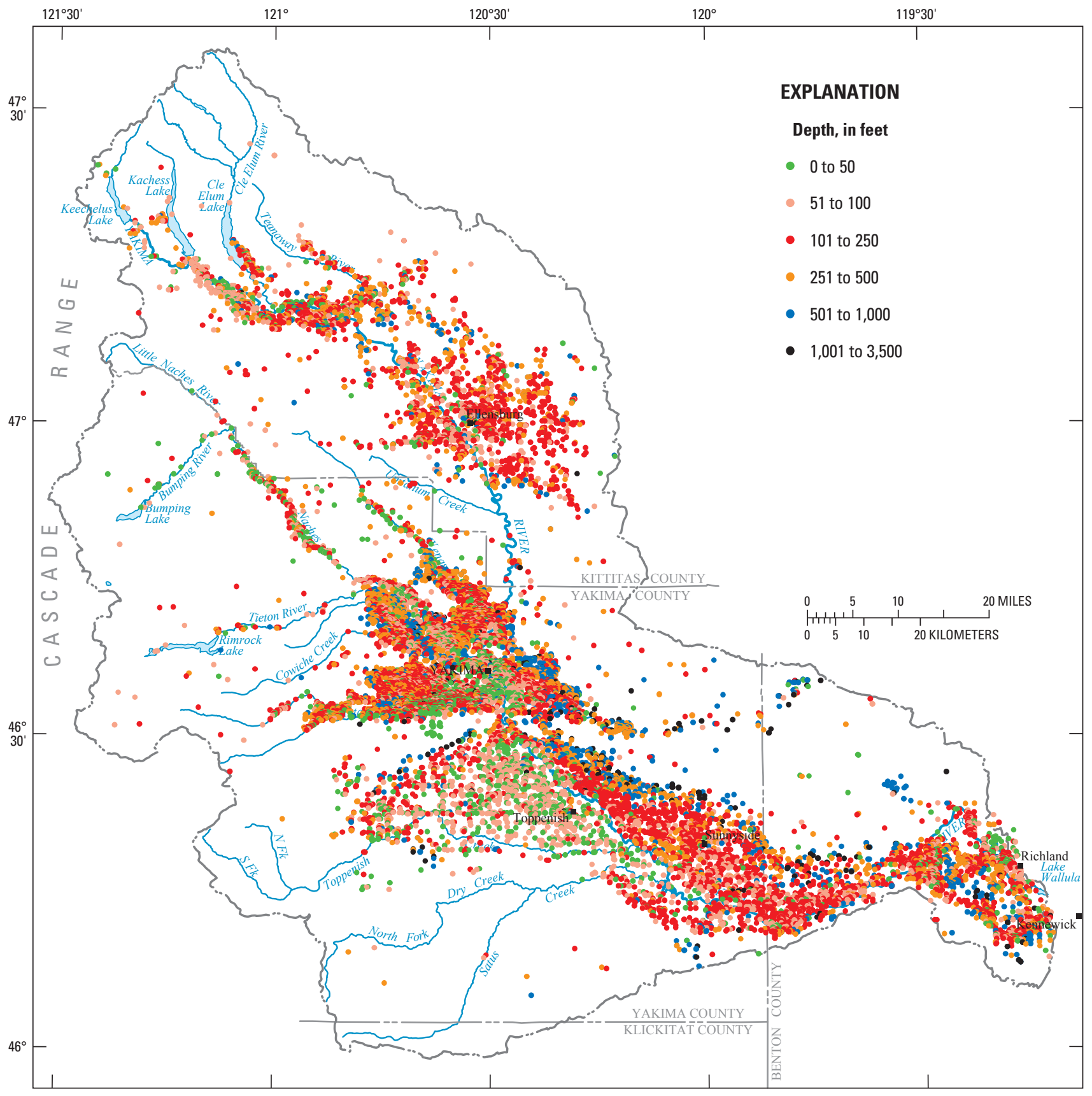

Figure 9. Distribution of depths of water wells, Yakima River Basin, Washington. 


\section{Ground-Water Uses}

Principal water uses in the Yakima River Basin include agriculture, public water supply, domestic, dairy and livestock operations, fish propagation, and commercial and industrial operations.

Most water used for agriculture is for irrigation, although some water is used for other activities, such as pre-irrigation, frost/heat protection, and fertilizer and pesticide application. Public water supply is for pumpage by municipalities and other Washington State Department of Health public water supply systems. Domestic use represents the self-supplied ground water used for drinking, preparing food, bathing, flushing toilets, cleaning and washing, and watering lawns and gardens. For this study, water for domestic use was assumed to be supplied principally by on-site, "exempt", wells for single family households. Generally, exempt wells pump less than 5,000 gal/d (about 5.6 acre-ft), irrigate one-half acre or less, and do not need a water-right permit or certificate. In addition, for this study domestic use includes some wells that have a water right to withdraw water for a single household. Dairy and livestock operations include livestock watering, equipment cleaning, and irrigating of grazing lands. Fish propagation primarily accounts for hatchery operations. Commercial and industrial use includes heat exchange, fruit and vegetable processing and storage, and manufacturing.

Eighteen Purpose of Use (PRU) codes are identified with the water rights in WaDOE's digital water-rights database (Water Rights Tracking System [WRTS]) (R. Dixon, Washington State Department of Ecology, written commun, 2001). These codes (10/31/2000 version) and their uses as defined in WRTS are:

- CI-Commercial and Industrial Manufacturing (includes food processing and packaging, sand and gravel processing, asphalt plant, metal processing and manufacturing, pulp and paper manufacturing, aquatic plant culture, petroleum refining, car washes, and laundries)

- DG-Domestic General (use of water for all domestic uses not specifically defined in the water right record or not defined by the other specific domestic use categories. Includes sewage treatment, farm supply, and laboratory use)

- DM-Domestic Multiple (more than one dwelling, i.e. motels, trailer courts, campgrounds, parks, schools, port districts, public utility districts, diking and drainage districts, water districts, reclamation districts, and counties, none of which are under municipal control)

- DS-Domestic Single (one dwelling with lawn and garden, up to one-half acre)
- EN-Environmental Quality (includes pollution control, dust control, flood control, or any water use which improves or maintains the quality of the environment)

- FP-Frost Protection (frost protection other than cranberries)

- FR-Fire Protection (includes sprinkling log storage facilities)

- FS-Fish Propagation (includes water service to ponds, reservoirs, hatcheries, and all other facilities involved in the overall purpose of fish propagation)

- HE-Heat Exchange (use of such equipment as heat pumps, refrigeration equipment, and other cooling devices)

- HW-Highway (maintenance and construction)

- IR-Irrigation (includes cranberry farming, lawn/ garden watering with definite acreage, golf courses, greenhouses, etc.)

- MI-Mining (includes washing coal, dredge mining, and hydraulic mining)

- MU-Domestic Municipal (serves general domestic, commercial, and industrial needs of an incorporated municipality, i.e. cities, towns, and outlying areas)

- PO-Power (includes hydro-electric, hydraulic ram, and thermo-electric)

- RE-Recreation and Beautification (includes beautifying private and public grounds and supplying water to swimming pools, boating ponds, etc.)

- RW-Railway (use of water to serve railway equipment and facilities)

- ST-Stock Watering (includes domestic uses of water for dairy/cattle farms, game bird farming, poultry farming, and fur-bearing animal farming)

- WL-Wildlife Propagation (includes water to service non-domesticated animals such as birds, game and non-game species)

These PRUs define the legal allowable use of appropriated water for a water right, which may have 1 to 4 PRUs. Note that the PRUs of DY (dairy operations), HP (heat protection for crops), and $\mathrm{CO}$ (cooling for industrial processes) were not included in the version of the above codes obtained from WaDOE but currently (2006) are included in WRTS. 
Considering water uses in the basin and the distribution and types of water-right uses, eight categories were defined for estimating, presenting, and comparing pumpage (table 1): (1) public water supply (includes a principal PRU of MU, DM, or, in some cases, DG and secondary PRUs of CI, HE, ST, FP, FR, and IR for wells with rights, and several wells without rights); (2) domestic (includes a single PRU of DS for wells with rights and exempt wells); (3) irrigation (includes all but public water supply systems rights with a PRU of IR and secondary PRUs of FP, ST, DS, DG, DM, EN, RE, HE, CI, and FS); (4) frost protection (includes all rights with a single PRU of FP); (5) livestock (includes PRUs of ST and DY and secondary PRUs of DS, DG, DM, EN, and CI for wells with rights and small dairies with exempt wells); (6) commercial and industrial (includes PRUs of CI, CO, HE, and RW and secondary PRUs of FR, DS, DG, DM, and EN, for the rights representative of commercial and industrial operations); (7) fish and wildlife propagation (includes all rights with a single PRU of FS or WL and two additional fish propagation [hatchery] wells); and (8) ground-water claims estimated to have existing pumpage not accounted for in categories 1-7 above. Note that categories 2 and 4-7 do not include a PRU of IR. Category 8 for ground-water claims primarily include PRUs of IR and secondary PRUs of DG and ST. Pumpage estimates for these claims are representative of the irrigation pumpage category, but are considered separate for analysis in this report.

Table 1. Relation between ground-water pumpage categories and water-right purpose of use codes in Washington State Department of Ecology's Water Rights Tracking System.

[x, denotes principal use; o, denotes secondary use; -, none. Ground-water pumpage categories: Public Water Supply includes some wells without rights that are public water supply. Domestic primarily includes domestic pumpage from exempt wells. Irrigation does not include irrigation pumpage for rights associated with public water supply and pumpage for claims. Livestock includes pumpage estimates for 19 small dairies that withdraw water under an exempt status. Fish and wildlife includes two wells used for fish propagation (hatchery). Water-right purpose of use codes: CI, Commercial and Industrial Manufacturing; CO, industrial cooling; DG, Domestic General; DM, Domestic Multiple; DS, Domestic Single; DY, Dairy; EN, Environmental Quality; FP, Frost Protection; FR, Fire Protection; FS, Fish Propagation; HE, Heat Exchange; IR, Irrigation; MU, Domestic Municipal; RE, Recreation and Beautification; RW, Railway; ST, Stock Watering; WL, Wildlife Propagation (see Appendix for further definitions of codes)]

\begin{tabular}{|c|c|c|c|c|c|c|c|c|}
\hline \multirow{2}{*}{$\begin{array}{l}\text { Water-right } \\
\text { purpose of } \\
\text { use codes }\end{array}$} & \multicolumn{8}{|c|}{ Ground-water pumpage categories } \\
\hline & $\begin{array}{l}\text { Public } \\
\text { Water } \\
\text { Supply }\end{array}$ & Domestic & Irrigation & $\begin{array}{c}\text { Frost } \\
\text { protection }\end{array}$ & Livestock & $\begin{array}{c}\text { Commercial } \\
\text { and Indus- } \\
\text { trial }\end{array}$ & $\begin{array}{l}\text { Fish and } \\
\text { wildlife }\end{array}$ & Claims \\
\hline CI & o & - & o & - & o & $\mathrm{x}$ & - & o \\
\hline $\mathrm{CO}$ & - & - & - & - & - & $\mathrm{x}$ & - & - \\
\hline DG & o & - & o & - & o & o & - & o \\
\hline $\mathrm{DM}$ & $\mathrm{x}$ & - & o & - & o & o & - & - \\
\hline DS & - & $\mathrm{x}$ & o & - & o & o & - & - \\
\hline DY & - & - & - & - & $\mathrm{x}$ & - & - & - \\
\hline EN & - & - & o & - & o & o & - & - \\
\hline FP & o & - & o & $\mathrm{x}$ & - & - & - & - \\
\hline FR & o & - & - & - & - & o & - & - \\
\hline FS & - & - & o & - & - & - & $\mathrm{x}$ & - \\
\hline $\mathrm{HE}$ & o & o & o & - & - & $\mathrm{x}$ & - & - \\
\hline IR & o & - & $\mathrm{x}$ & - & - & - & - & $\mathrm{x}$ \\
\hline MU & $\mathrm{x}$ & - & - & - & - & - & - & - \\
\hline $\mathrm{RE}$ & - & - & o & - & - & $\mathrm{x}$ & - & - \\
\hline RW & - & - & - & - & - & - & - & - \\
\hline ST & o & - & o & - & $\mathrm{x}$ & - & - & o \\
\hline WL & - & - & - & - & - & - & $\mathrm{x}$ & - \\
\hline
\end{tabular}




\section{Ground-Water Rights}

Ground-water rights consist of three categories, (1) certificates, (2) permits, and (3) valid claims. In addition, there are outstanding applications for new rights and for changes and transfers of existing rights. Based on information in WRTS and some additional information provided by WaDOE, there are about 2,575 certificates, 299 permits, 859 outstanding applications, and more than 16,600 claims in the basin. WRTS contains only selected information from the actual water right document. A permit or certificate represents a right (appropriated water) to withdraw and use ground water, whereas a claim may or may not be valid. For a claimant to have a permit or certificate, the claim would have to be upheld in an adjudication process.

Most pumpage categories are based on ground-water rights. Therefore, the accuracy of the estimates to some extent are dependent on the accuracy of information in WRTS. Rights with values deemed questionable were sent to WaDOE for verification and any errors were fixed in the databases developed during this study. Some valid rights in the basin are not in WRTS, but determination of these rights was beyond the scope of this study. For example, a list was compiled of 381 wells with some type of water-right identifier on the well log that could not be found in WRTS. An analysis of this information by WaDOE (J. Kirk, Washington State Department of Ecology, written commun., 2005) indicated that either the well did not have a right, the right was relinquished, the right was valid but the well was outside of the basin, or it was a valid right that was not in WRTS. About 30 of the 381 wells had valid rights or about 1 percent of the total rights. However, total pumpage from other rights not in WRTS should be minor compared to cumulative estimates presented in this report because the rights for all major public water supply providers and irrigators are accounted for.

\section{Background}

A water right has a priority date, purpose of use (the PRU), point(s) of withdrawal (POW-identified by township, range, and section (TRS) in WRTS), place of use (POU), and an allowable quantity to be pumped. The POU is not included in WRTS. Allowable quantity is the appropriated quantity, sometimes called the entitlement or authorized amount. These terms are used interchangeably in this report. Quantity is expressed as both a maximum instantaneous rate in gallon per minute (gal/min) and as an annual value in acre-ft. For 21 rights, either the instantaneous rate or the annual value was not listed in WRTS; therefore, the sum of the allowable quantity for either quantity category is not a complete total. For rights with a PRU of IR, FP, and (or) ST, the maximum acreage to which the water can be applied also is in WRTS, and is related to the POU. Not included in the number of and quantities for the rights listed below, is information from the additional 30 rights that were not in WRTS; these rights total about 21,000 acre-ft of appropriated water, of which about 6,700 acre- $\mathrm{ft}$ is outside the basin.

The total quantities for the certificates and permits are:

\begin{tabular}{lcccr}
\hline & $\begin{array}{c}\text { No. of } \\
\text { certificates } \\
\text { and permits }\end{array}$ & $\begin{array}{c}\text { Instantaneous } \\
\text { (gal/min) }\end{array}$ & $\begin{array}{c}\text { Annual } \\
\text { (acre-ft) }\end{array}$ & $\begin{array}{c}\text { Irrigated } \\
\text { area (acres) }\end{array}$ \\
\hline Certificates & 2,575 & 720,683 & 422,040 & 101,371 \\
Permits & 299 & 230,623 & 107,191 & 28,199 \\
\hline
\end{tabular}

These values include primary and standby/reserve water rights. A primary water right can be used at all times for the PRU during the allowable time period defined in the water-right document for the right. Standby/reserve rights are associated with and supplemental to a primary irrigation right, almost always a surface-water right. The standby/ reserve rights allow the use of ground water only during years when the TWSA cannot meet all demands; these years include emergencies and (or) droughts. The methods used to distinguish between primary and standby/reserve rights are described in a following section.

Outstanding applications were not analyzed during this study. As of 2001, 859 applications represented a total potential instantaneous rate of $616,306 \mathrm{gal} / \mathrm{min}$ and a total irrigated acreage of 64,308 acres, about 50 percent of the allowable irrigated acreage in 2000. Claims are not addressed in this part of the report; they are discussed in a later section as a category of ground-water pumpage.

\section{Relation between a Water Well and a Water Right}

A well or wells associated with a right were identified, including when possible, the drillers' log or logs. This association was needed to (1) help estimate ground-water pumpage (withdrawals of appropriated water account for most pumpage); (2) compare estimated pumpage from individual wells to the appropriated right; (3) identify hydrogeologic unit or units that a right/pumpage is associated with; and (4) provide data to simulate effects of pumpage in ground-water flow models. To make these associations, various databases were examined. 
The Central Regional Office, Water Resource Program, of WaDOE developed a digital database for ground-water rights for the lower part of the Yakima River Basin (WRIA 37). For a right, the database generally lists the TRS (and sometimes the quarter-quarter section), a water-right number (Control ID, also listed in WRTS), well information such as depth, diameter, and name on the well log, and in some cases, a well number for a well based on the well numbering system for the State; the well number either was assigned by WaDOE or was a USGS well number. Personnel from the USGS examined in-house paper copies of drillers' (well) logs to associate a log with a listing in the database. Paper copies are organized by county and within a county by the well number. This step was completed to (1) verify that information in WaDOE's database matched information on a well log (well depth, owner, construction date, etc.), (2) add the Control ID to the well log, if necessary, and (3) determine if a well log with a Control ID matched a listing in WaDOE's database. For many older rights, the Control ID was not listed on the log, but the original application, document, and (or) certificate number was listed. For these cases, WRTS, which contains the original certificate number for some rights, was searched to determine if a matching certificate number was available to determine the Control ID. In addition, the original application number generally is similar to part of the Control ID, so the database was searched for the application number. Otherwise, WRTS was searched for the owner's name, right, and (or) TRS.

If a paper well-log could not be found for a right listed in the digital database, NWIS was checked to determine if a well matched a database listing. In some cases no in-house well-log was available, but an original field-visit sheet was found with the Control ID or other pertinent information, such as a measured water-level. When no matching log could be found, WaDOE's on-line well-log database (Washington State Well Log Viewer: http://apps.ecy.wa.gov/welllog, accessed August 16, 2006) was searched to determine if the well log was available. If the well log was available, it was printed and filed with the NWIS well paper copies for NWIS wells or it was filed separately for later input of pertinent information into NWIS for non-NWIS wells.

For the rights with a POW outside the area included in the lower-basin digital database, the same techniques were used, starting first with the in-house paper copies. These rights were more difficult to associate with a log because WRTS does not contain well information. Checking was based on the POW, ownership name for the right, date of priority, and the PRU. Searches of paper copies, digital information (organized by well number) compiled as part of this study, and the on-line database started with all wells in the TRS listed as the POW for the right.
To associate water rights and well logs, as many as possible of the public water supply wells were associated with a right. This task was difficult because of numerous public water supply systems in the basin (not all of which have rights) and many of the systems have names with no relation to the name on the right or the well log. Also, many systems use wells that were initially drilled for single or multi-household use and were later converted to a public water supply system. In addition, most smaller systems do not have a right because they pump water under an exempt status. However, it was the goal to associate as many of the systems to a right, when applicable, and (or) a log. In some cases, public water supply rights were associated with a log, but not with a Washington State public water supply system.

Of the 2,874 active rights, all but 220 were associated with a well $\log$ or logs. In addition, the total number of wells associated with rights was greater than the number of rights because: (1) a right might be associated with more than one well due to a well deepening or reconditioning; (2) a right may have more than one POW; and (or) (3) a well may have been replaced by another well. Forty-eight of the 220 rights without associated logs were assigned some well information based on information from WaDOE's lower-basin database.

A digital file was developed that contained information from WRTS, a USGS well number, and well information such as depth, location, and openings. Location is based on reasonable estimates of latitude and longitude of wells field visited by either USGS or WaDOE or by the center of the POW section. In some cases, a quarter or quarter-quarter section for a right was identified by WaDOE or by the USGS based on information from a drillers' log; for these cases, the latitude and longitude of the center was used as the location. This file contains some errors in associations between rights and well logs because: (1) actual water-right documents were not examined; (2) incorrect water-right identifiers may be on a well-log or logs; (3) well owner may have multiple wells and only one or some of these wells may be associated with a right (the Control ID may be on all $\operatorname{logs}$ ); and (4) there was a replacement well but the replacement well log was not found or examined because the original log for the right was found and it was assumed this was the correct (existing) well for the right.

For all rights, the latitude and longitude of a well also was checked to ensure that the well was in the correct TRS, and for most wells, in the correct quarter-quarter section. A unique sequence number, based on the well-numbering system was assigned to wells not in NWIS and input to the digital file containing the well and water-right information. 


\section{Primary and Standby/Reserve Water Rights}

Standby/reserve rights have a principal PRU of IR and (or) FP, and generally, but not always, are associated with use of a well in a year when the TWSA cannot meet the appropriated surface-water rights and the junior surface-water users would have their appropriated water prorated. After 1945 , prorating occurred in 1973, 1977, 1979, 1987, 1988, 1992, 1993, 1994, 2001, and 2005. In these years, junior surface-water rights (typically post-1905) in the basin were prorated and the full appropriated quantity was not available. Prior to 1977 , prorating of junior rights occurred only in 1973, when junior users received about 80 percent of their appropriated quantity. It was not until 1977, when the initial forecast of the prorating was about 40 percent for the junior entitlements, that there was need to drill a well for standby/ reserve use. This is especially true because of the cost of developing a ground-water supply. Starting in 1977, numerous wells were drilled by junior users for supplemental irrigation, which generally, but not always, occurred in September and October. Most standby/reserve rights are in the lower part of the basin.

Standby/reserve rights consist of two categories. The first category allows the water-right holder to use the right when the total amount of the prorated allotment is used. Many early standby/reserve rights are in this category. However, the allowable quantity listed in WRTS may not be the actual quantity allowed. A water-duty was assigned to earlier rights, generally based on the surface-water duty, about 3-5 acre-ft/acre, (quantity divided by acreage-yielding a water duty of acre-ft per acre as the allowable application rate), but in the water right document (not in WRTS) this quantity generally was limited to a lesser value. Not until about 1980 were more standby/reserve rights assigned base-level water duties of about $0.5-2$ acre-ft/acre.

For the first category, a few rights are standby/reserve to a primary ground-water right. In addition, a few but unknown number of rights issued as standby/reserve rights under the first category actually are primary rights because the water-right document did not explicitly state that the right was standby/reserve for use in years in which a junior surfacewater user has the appropriated water prorated (J. Kirk, Washington State Department of Ecology, oral commun., 2005). The actual number of such standby/reserve rights was not determined, but the number is very small.

Standby/reserve rights for the second category were approved for one-time use starting with the 2001 drought and again during the 2005 drought. These "emergency permits" were issued when a drought was declared. Wells with emergency permits cannot be used in another year unless authorization for withdrawal is approved (essentially issuing a new emergency permit).
In lieu of reviewing all the paper and microfiche waterright documents in WaDOE's office, a method was developed to estimate which rights are standby/reserve. First, standby/ reserve rights were assumed to be in surface-water irrigation districts with proratable rights. Therefore for each well with a right (particularly for the 2,226 rights that have both a PRU of IR and allowable acreage for irrigation), it was first estimated if the well was located within an irrigation district. The irrigation district boundaries were obtained from Reclamation (E. Young, Bureau of Reclamation, written commun., 2002). These boundaries (fig. 10) are primarily based on 1974 maps that show irrigation districts in Washington State. The maps originally were developed at a smaller scale and are approximate in some areas. Wells near a boundary may be inside or outside of an irrigation district. Locations of selected wells (based on the PRU, allowable quantity, and priority date of a right) near an irrigation district boundaries were examined in more detail to determine whether they were in the district boundaries.

Several assumptions were made to estimate the type of right (primary or standby/reserve) for wells in an irrigation district. The first assumption was that all rights with a priority date before 1977 were primary rights. About 21 wells associated with rights in irrigation districts were constructed prior to 1977 , but their water rights have a priority date after 1976; for this study, these rights were assumed to be standby/ reserve, but some of these may hold primary rights. The next assumption was that all right holders with fewer than 5 allowable acres for irrigation had primary rights, regardless of the priority date.

For irrigation rights with a POU of 5-10 allowable acres, an estimate of whether a right was primary or standby/ reserve was made based on the water-duty, PRU, location, priority date, and information from the well $\log$. Of the 2,226 rights with allowable irrigable lands (excluding rights with a single PRU of FP), 925 rights have IR as the only PRU. The remaining rights have multiple purposes, including DS, DM, DG, CI, FP, FR, HE, DY, ST, and EN. If a right was not obviously primary, it was assumed to be standby/reserve. This same methodology was used for rights with larger allowable irrigated acreage and, in addition, field notes (such as "well is used continuously during irrigation season"), information on well logs, and the well locations were examined in detail.

Using these methods, about 560 rights were designated as standby/reserve; 2 rights are supplemental to a ground-water right. For the 25 rights with a PRU of FP and no PRU of IR, 21 were estimated to be standby/reserve. Based on knowledge of water rights in the basin, WaDOE concurred with this approach and indicated that it should provide a reasonable estimate of standby/reserve rights (J. Kirk, Washington State Department of Ecology, written commun., 2005). 


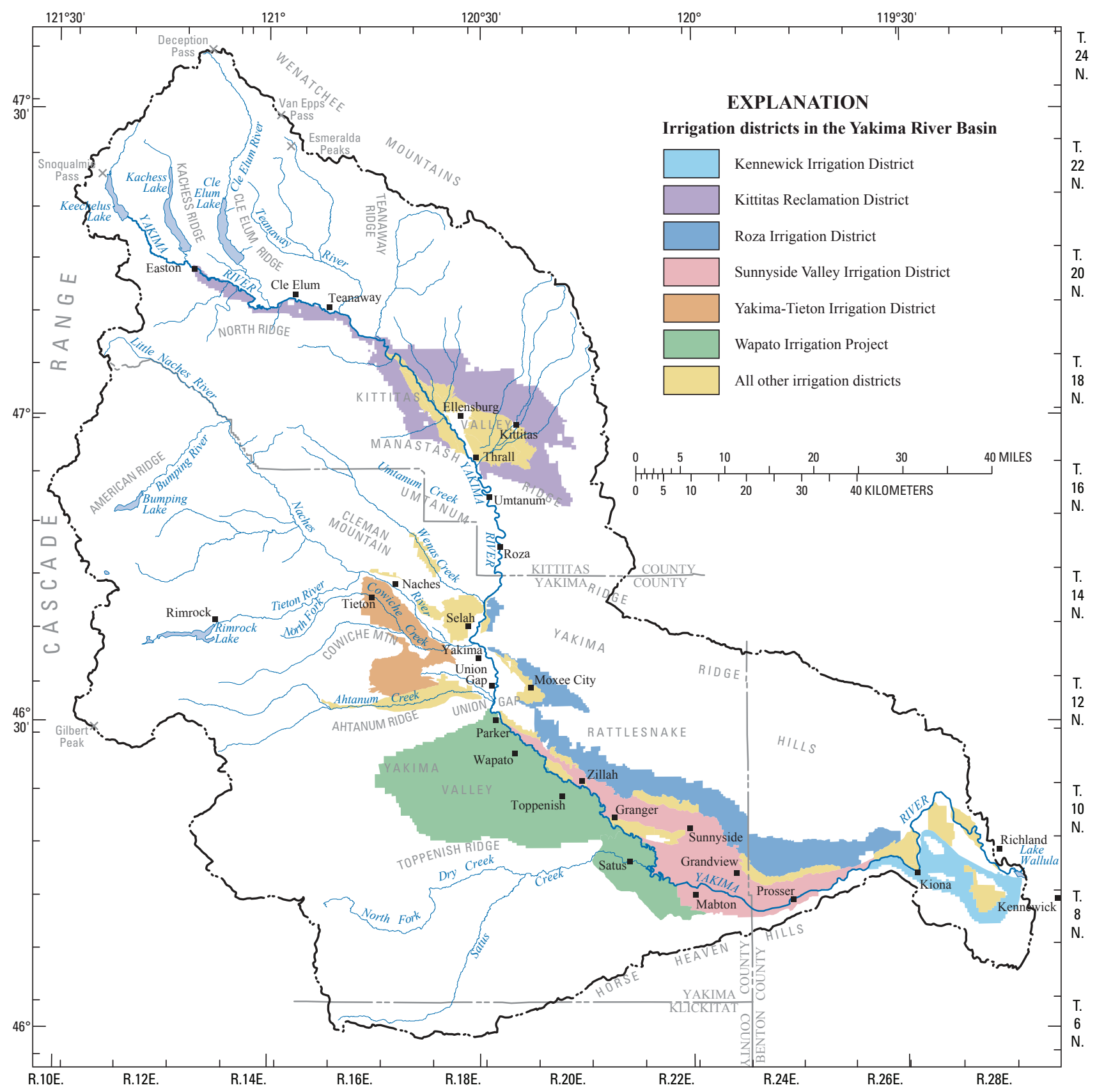

Figure 10. Location of surface-water irrigation districts, Yakima River Basin, Washington. 


\section{Methods Used to Estimate Ground-Water Pumpage}

The methods used to estimate pumpage were predicated on the difficulty in gathering data or measuring pumpage; pumpage is the least known part of the basin's water budget because of the lack of existing data. Few measured values are available from several pumpage categories because the wells either are not metered (owners do not know how much they use), a well system set-up does not allow direct measurement, information is considered proprietary, or in a few cases, the wells are no longer used. Therefore, various methods were used to estimate pumpage, including using hydrologic judgment based on existing information and previous work. Methods used vary based on the principal PRU of each category. Methods range from compiling and extrapolating compiled (provided) information to estimating that the full appropriated quantity is the best pumpage estimate for a category. For rights in a category that include certain additional PRUs, such as DM for workers, the Washington State Department of Health's (DOH) Water System Design Manual (Washington State Department of Health, 2001a) was used as a guide for estimating additional pumpage for those PRUs.

The start date associated with pumpage is assumed to be the well completion date and that the well is then used for its designated PRU. When the well-completion date was unknown and the well had a water right, the start date was assumed to be the priority date of the water right. For example, if an irrigation well was drilled in 1920 and its associated right had a priority date of 1950, the 1920 date would be used as the start of irrigation pumpage. Examination of numerous drillers' logs indicates that this is a reasonable assumption, especially for wells drilled prior to about 1970. Exceptions for defining the start date of public water supply pumpage and domestic pumpage are described below.

It is also assumed that the methods are applicable for any particular year. This implies that the same amount of water would be used by a particular user or users in any year. For example, the assumption is that a household uses the same amount of water each year. However, pumpage varies year-toyear for various reasons. It was beyond the scope of this study to attempt to estimate interannual variations that may occur for any particular category of pumpage due to changing water-use practices.

\section{Public Water Supply}

For this study, public water supply (PWS) withdrawals primarily included water systems that are part of the DOH's Group A and Group B systems. Group A systems generally have 15 or more service connections and Group B systems generally have 2 to 14 service connections. For this study, Group A water systems serving incorporated areas, referred to as municipal systems, were considered separately from other Group A systems. The DOH database for the three-county area has 325 Group A systems that serve about 302,000 people and 1,285 Group B systems serving about 10,600 people. Group A systems principally serve both municipalities and residential developments. Not all these systems are in the basin boundaries. Water-right wells with a single PRU of DM (some also may have a second PRU of IR, but the IR part of the right is minimal compared to the DM part) that provide drinking water to households, but are not part of a Group A or B system also are included as part of the PWS category.

Twenty-four water purveyors in incorporated areas, generally representing the largest Group A systems (municipalities), were asked to provide existing records for pumpage from 1960 through 2000 and the corresponding populations served. All purveyors provided at least monthly records for some years for that period and population-served data for 2000. Several purveyors provided weekly or daily values, which were compiled into monthly values. Provided pumpage values represent PWS and include all water pumped by a municipality for distribution.

Population-served data were analyzed in conjunction with the State of Washington, Office of Financial Management census (from the U.S. Census Bureau [U.S. Census Bureau, 2004]) and intercensus (estimated annual population between 10-year U.S. Census Bureau surveys, by county, for incorporated and unincorporated areas) data (Washington State Office of Financial Management, 2002) to calculate a ratio of population served to census population for each year of available data for the municipalities. Calculated ratios were then multiplied by census or intercensus data from 1960 through 2000 to estimate an annual population served; the final population served estimates were for each system for years with no available population-served data.

Available pumpage and population-served data then were used to calculate an average annual per capita pumpage rate for each municipality for the period of available data. Average per capita rates varied from 38 to $554 \mathrm{gal} / \mathrm{d}$ with 75 percent 
less than $180 \mathrm{gal} / \mathrm{d}$ and 50 percent less than $129 \mathrm{gal} / \mathrm{d}$. The per capita rate was then multiplied by estimated population served to obtain annual totals of pumpage for years without available data. Calculations resulted in a complete record of observed or estimated pumpage for the 24 systems for 1960 through 2000. Implicit in these calculations is that the non-drinking water part (commercial, industrial, and irrigation) of the total pumpage remained constant over time. This part is known to change with time because total industrial and commercial use of water is slowly declining (Dion and Lum, 1977). Data provided by larger systems indicated that the commercial and industrial part of total pumpage ranged from about 4 percent to as much as 60 percent; the larger values are for small municipalities that seasonally provide a large quantity of water to fruit and vegetable processing plants. Except for some older unused municipal wells, most wells have an identified latitude and longitude based on either site visits or global positioning coordinates provided by the municipality or $\mathrm{DOH}$.

All other Group A and B water suppliers were asked if pumpage data were available. These non-municipal systems typically provide water to households and do not generally provide water for industrial and commercial purposes. Twenty-three Group A systems and 40 Group B systems provided pumpage information. Population-served data for these systems were obtained from the DOH's, Office of Drinking Water, web site (Washington State Department of Health, 2001b). Based on pumpage data and population served, a per capita rate was calculated for each system for each year that withdrawal data were available. If a per capita rate appeared too low or too high (a potential outlier), the system operator was contacted to obtain additional information or to verify the provided information. Rates for the systems ranged from 10 to $1,800 \mathrm{gal} / \mathrm{d}$ and 90 percent of the values were less than $600 \mathrm{gal} / \mathrm{d}$. The resulting per capita values were then used to calculate a basin-wide average per capita rate of $251 \mathrm{gal} / \mathrm{d}$, weighted by population served. However, the three highest rates $(1,800,1,040$, and $935 \mathrm{gal} / \mathrm{d})$ were not used in the calculations because the highest value appeared to be in error and the next two highest values, although not unreasonable based on reported values for eastern Washington (Washington State Department of Health, 2001a), appeared to be outliers for actual pumpage in the basin. A basin-wide average was calculated because data from individual systems displayed no spatial trends. Data for municipalities were not used in the calculations because their usage is not representative of smaller systems, which do not supply commercial and industrial water and generally do not supply high density, multi-residential properties such as apartment buildings. For systems in the surface-water irrigation districts (fig. 10), a reduced average rate of $109 \mathrm{gal} / \mathrm{d}$ was calculated based on the average of several larger systems in irrigation districts. The reduced rate was used because many households in these districts use surface water for lawn and garden watering.

The appropriate average rate then was multiplied by population served for all years for all systems with no available pumpage data. Although an average rate should capture the overall pumpage, estimates for some systems will be too small or too large. Locations for many of the Group A systems were identified using a Global Positioning System (Washington State Department of Health, written. commun., 2003); whereas, most of the Group B systems have locations at the center of a section, quarter section, or quarter-quarter section. Estimated start year for a system is "effective source date" from DOH's database; some systems probably were operating prior to the effective source date. About 150 systems did not have population served data and no estimates were made for these systems, which principally include campgrounds, small stores, churches, taverns, and a few commercial operations.

Pumpage for PWS varies greatly on a seasonal basis. To estimate month-to-month variation in pumpage, a percentage of annual pumpage for each month was calculated. This percentage was based on total pumpage for all systems that provided information for the most current year, usually 2000 . In turn, pumpage for each month was totaled for all systems and then divided by the annual total. These calculations yielded an effective monthly percentage of annual pumpage for the basin. These values will be used for other components of this study to estimate monthly pumpage for the systems with no available data.

\section{Domestic}

Domestic pumpage is composed of two parts: pumpage for ground-water rights and pumpage from exempt wells. Domestic pumpage is negligible for ground-water rights compared to exempt-well pumpage, but it is important to obtain an accurate estimate as possible for total water-right pumpage in the basin. Excluding some dairies, other allowable potential pumpage from exempt wells was not estimated as part of this study because of lack of information. 


\section{Ground-Water Right Wells}

Ground-water right pumpage estimates were made for all wells with a PRU of DS as its principal use. Fifty-nine associations were for wells with rights with a single PRU of DS and 4 rights had a second PRU of either HE or FP. For wells outside of irrigation district boundaries, $251 \mathrm{gal} / \mathrm{d}$ per capita was used to estimate a value for 2.3 persons per household, yielding a pumpage rate of 0.65 acre-ft per household. For wells in irrigation districts, $109 \mathrm{gal} / \mathrm{d}$ per capita, described previously, was used to estimate a value for 2.3 persons per household, yielding a pumpage rate of 0.28 acre-ft. One right had a small associated acreage for application of water; IR was not a PRU and this right was not included as part of the irrigation estimates (except for two rights, all pumpage associated with the irrigation estimates include a defined PRU of IR). Based on water requirements for a well-watered lawn, estimates are that 2.5 acre-ft/acre was pumped for lawn watering.

Two DS rights were for businesses. For a smaller business $250 \mathrm{gal} / \mathrm{d}$ ( $0.28 \mathrm{acre}-\mathrm{ft})$ was assumed to be pumped and for a larger business $500 \mathrm{gal} / \mathrm{d}(0.56 \mathrm{acre}-\mathrm{ft})$ was used as the pumpage estimate. Another right was for a nursing home, but notes from a field visit of the property's well indicated that the well was used only for irrigating about 1 acre in summer, and 2.5 acre-ft was assigned to this right. One right was for a small Forest Service campground. Assuming 20 people per day used $20 \mathrm{gal} / \mathrm{d}$ during May through October resulted in a pumpage estimate of 0.22 acre-ft. One right had an additional PRU of HE for a domestic ground-water heat pump for which a value of 0.01 acre-ft was used; this quantity is returned through another well. Two rights in an irrigation district had an additional PRU of FP with 4-8 allowable acres. Frost protection pumpage for these two rights was assumed to be negligible.

Similar methods were used to estimate the domestic part of pumpage for other pumpage categories with principal PRUs of IR, FP, HE, CI, and (or) ST and a secondary PRU of DS. These latter pumpage estimates are not included as part of this category because pumpage for these other principal PRUs is much larger than for a single household; that is, the estimated pumpage is generally much larger for the above PRUs than for the DS part. In addition, to retain total pumpage associated with a right and a well, the estimates for the DS part are included in the total for the right under the other categories.

\section{Exempt Wells}

Average per capita pumpage rates (109 and $251 \mathrm{gal} / \mathrm{d}$ ) calculated from data provided by water purveyors were used to estimate the pumpage by exempt wells (wells not requiring a water right, primarily used for self-supplied domestic use, and use less than 5,000 gal/d). To use the per capita rates, an estimate of population served by exempt wells was first made. The 2000 U.S. Census Bureau data for population in census blocks (U.S. Census Bureau, 2004) for the unincorporated part of the study area (fig. 11) were used in conjunction with population served information for all Group A and B systems to estimate the population using exempt wells.

The PWS population served was subtracted from the census block population to obtain a population estimate for exempt wells. The average per capita rate $(251 \mathrm{gal} / \mathrm{d})$ was then multiplied by the exempt population in each block to estimate exempt pumpage by block. For blocks in irrigation districts, the reduced per capita rate $(109 \mathrm{gal} / \mathrm{d})$ was used to estimate exempt pumpage. Using exempt population and households per block, an estimate also was made of the number of exempt wells in a block.

Based on estimated population using the 2000 census and the State of Washington Office of Financial Management intercensus data (Washington State Office of Financial Management, 2002), an estimate also was made for 1995. A ratio was calculated for intercensus 1995 population to 2000 population for unincorporated areas, by county. This ratio then was assumed to apply to all unincorporated blocks, and the 2000 population estimate in each block was multiplied by the ratio. Population served in 1995 for the PWS systems was then subtracted as above. The exempt pumpage calculations were then made using the same methods used to estimate pumpage for 2000. This process was used to estimate pumpage for 5 -year increments to 1960. However, DOH's information on PWS systems did not start until 1970. For this study, Group A and B systems operating in 1970 were assumed to be also operating in 1960 and 1965. Therefore, exempt pumpage was estimated for each unincorporated census block for 1960-2000, but the actual location of pumpage in a census block is not known. 


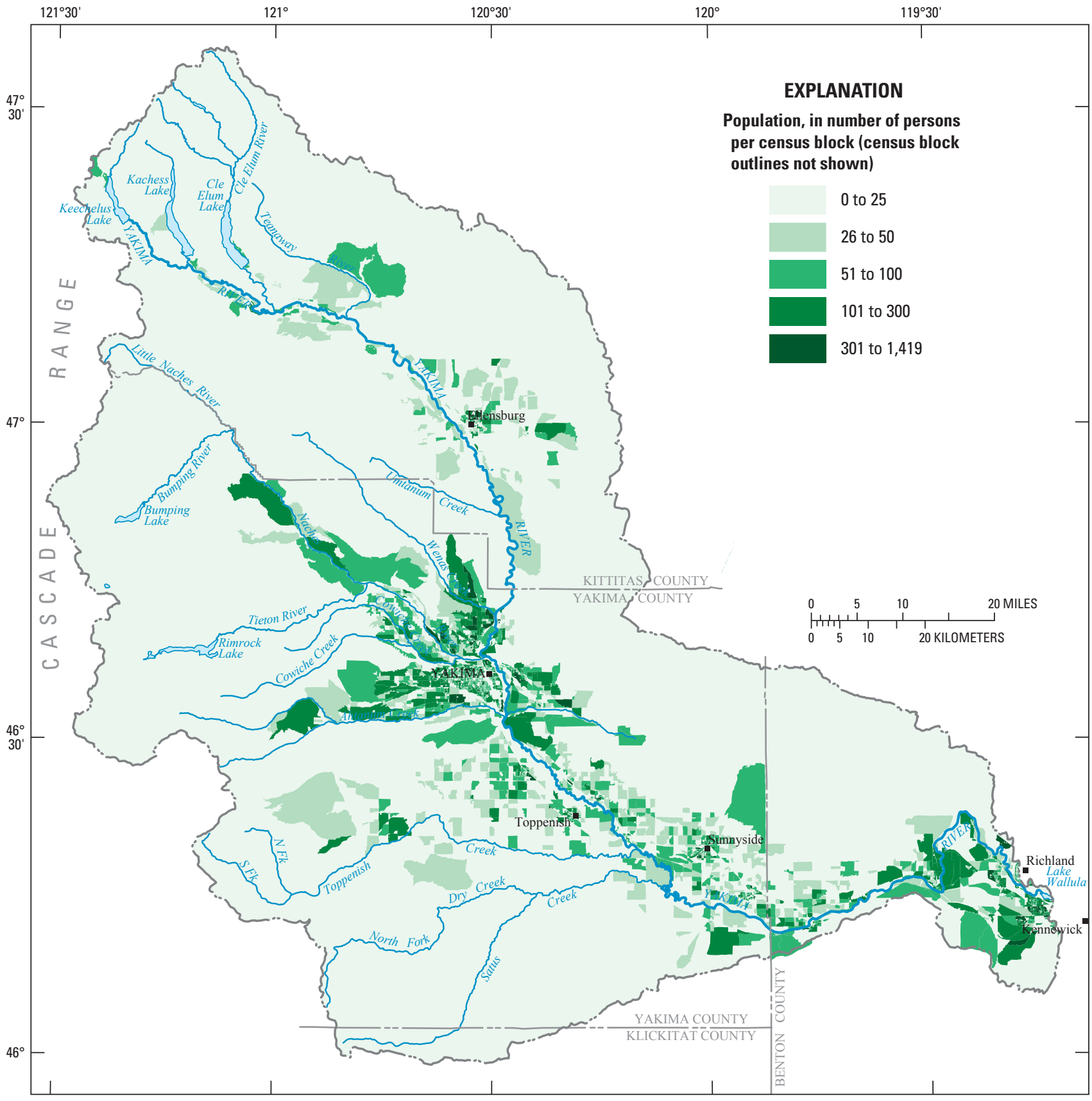

Figure 11. Distribution of census blocks and population, Yakima River Basin, Washington, 2000. 


\section{Irrigation}

Irrigation pumpage estimates were made for most wells with irrigation rights and allowable acres in the WRTS database. A total of 2,226 rights had allowable acres for irrigation, and all but 2 rights had IR as a use. These latter two rights had a PRU of DM with large allowable acreage known to be associated with either pastures or orchards. Much of the pumpage for these two rights is associated with irrigation, and estimates are that the DM part of the appropriated right was for workers' use. Seventeen rights with a single PRU of IR with a total annual quantity of about 4,220 acre-ft were for municipalities, and withdrawals for these 17 rights are included as part of the PWS estimates. Fifty-eight rights were associated with non-municipal PWS with a total allowable acreage of about 1,010 acres. Pumpage for these rights is included as part of the PWS pumpage because the irrigation part is assumed to be accounted for in the PWS estimate. One right with allowable acreage was for a PRU of DS and no PRU of IR; the estimate for this right is included in the domestic right estimates. As a result, 2,150 rights were analyzed for pumpage and these rights include about 123,400 acres of allowable irrigated lands.

Pumpage estimates were derived using allowable irrigated acres, annual acre-feet application rate (the water duty—appropriated annual rate divided by acres), crop type, and estimates of average crop-water use. For the lower part of the river basin that included parts of Yakima and Benton Counties, Pacific Power provided power consumption data for their irrigation pricing-schedule users aggregated by zip code due to the proprietary nature of the information (Pacific Power, written commun., 2001). The power information was used to obtain a coarse estimate of pumpage for this part of the basin based on generalized power consumption-pumpage equations. This estimate was used to help assess the reliability of the irrigation pumpage.

This study originally was designed to use a detailed power-consumption method to estimate pumpage for many larger users. This method relies on accurate readings of well discharge using an acoustic velocity flowmeter, accurate pipe thickness measurements, power records, transformer information, and well information. Visits to more than 300 wells resulted in only 18 reliable measurements because few well systems met the criteria for flowmeter use. For wellpumping systems where this method was used, calculated pumpage was used as the estimate and also to estimate the reliability of the crop-water use method.

To apply the crop-water use method, a crop-type GIS database was generated using several data sources. Reclamation provided (1) a GIS database for the basin that identified irrigated lands, but no crop type, and (2) GIS databases for crop types for several smaller areas (E. Young, Bureau of Reclamation, written commun., 2003). Kittitas Conservation District provided a crop-type distribution for most of Kittitas County (Kittitas Conservation District, written commun., 2003), and South Yakima Conservation District provided information for Roza and Sunnyside Valley Irrigation Districts (fig. 10) (South Yakima Conservation District, written commun., 2004). Land use/cover for the basin was obtained from the USGS's national database (Homer and others, 2004), and a detailed crop-type coverage for a small subbasin near Granger was developed by the USGS as part of the National Water Quality Assessment Program. A field survey was conducted as part of this study for the Wapato Irrigation Project (fig. 10) to identify fields with orchards, vineyards, and hops. Additional field surveys were completed in selected areas identified as irrigated lands from either the Reclamation or the USGS data sets, but the crop types were not known. A 2004 geodatabase of fields with irrigated crops was obtained from Washington State Department of Agriculture (DOA), Pesticide Management Division (T. Maxwell, Washington State Department of Agriculture, written commun., 2005). This database contained information on field size, crop types, and irrigation methods, aggregated to the section level. However, determination could not be made where a field was in the section because information was at the section level, and the geodatabase was not used to develop the crop-type database. However, the geodatabase was used for other checks on crop type. Land-use/cover information for the basin was combined into a single spatial database, starting with the least detailed data and substituting in the more detailed data sets. The resulting database was assumed to represent all years for which irrigation pumpage was estimated.

Each water-right well then was assigned to the crop type at the well. The resulting crop types at wells were compared with DOA data, allowable acres, and PRU to: (1) determine their reasonableness and (2) estimate a crop type for wells associated with irrigated lands having unknown crop types. For each right, the allowable annual application rate (the water duty) was compared to a crop water-use rate, and the smaller value was multiplied by the allowable acreage to estimate annual pumpage. The crop water-use rate was an average for each crop based on 50 years of daily calculations of potential crop evapotranspiration, which does not account for off-season precipitation or soil moisture. An irrigation-efficiency factor was not applied to the rate because the crop rate could be high, the rates varied by as much as 3-4 in. over the 50 -year period, and precipitation was not accounted for. Overall, using such an average rate without an efficiency factor should capture the average pumpage. This method of applying crop water-use 
rates was used by Cline and Collins (1992) and Van Metre and Seevers (1991) to estimate pumpage in the central Columbia Plateau and proved to be reliable.

Power consumption methods for estimating pumpage are well documented and were previously used to estimate pumpage in the central Columbia Plateau (Collins, 1987; Cline and Knadle, 1990; Van Metre and Seevers, 1991; Cline and Collins, 1992). In one method, an effective total operating head value would be needed for each zip code area with the aggregated power data. Obtaining such a value would be difficult if not impractical because of large variations in well construction and depth in a zip code area.

Another power consumption method relates a known pumping rate to power consumption to derive a power-consumption coefficient (PCC), which is energy consumed per acre-ft of water pumped in units of kilowatt hours per acre-ft (kWh/acre-ft). The $18 \mathrm{PCC}$ values calculated in this study ranged from 418 to $3,563 \mathrm{kWh} / \mathrm{acre}-\mathrm{ft}$, with a median of $970 \mathrm{kWh} / \mathrm{acre}-\mathrm{ft}$. Based on numerous measurements from previous studies, the PCC generally ranges from about 400-500 kWh/acre-ft for pressure systems (Hurr and Litke, 1989).

Collins (1987) used flowmeter and power consumption data for the Columbia Plateau, Oregon, to develop two equations relating annual power consumption to annual pumpage:

$$
\begin{gathered}
Q=0.000865 * K+39.09 \\
Q=0.00193 * K+66.88
\end{gathered}
$$

where

$Q$ is annual pumpage, and

$K$ is annual power consumption.

Equation 1 was for basalt wells and equation 2 for the sedimentary material overlying the basalts.

For each zip code area in the lower basin with power consumption data, pumpage was estimated based on the 400 and $970 \mathrm{kWh} /$ acre-ft PCC values and equations 1 and 2 . Together, the four calculated values of pumpage provided a range in potential pumpage. To differentiate between surfaceand ground-water power consumption for irrigation in a zip code area, total irrigated area in a zip code area was estimated from the land-use/cover data. The percentage of irrigated lands in a surface-water irrigation district was then calculated. The remaining percentage was multiplied by the power consumption to estimate ground-water power consumption in an area, which was used with the PCC values and equations
1 and 2 to estimate a potential range in pumpage. This method assumes that power consumption for surface- and ground-water systems is the same.

Eight hundred eighty-one rights had an additional PRU of DS. For these rights, 0.40 acre-ft (about $154 \mathrm{gal} / \mathrm{d}$ per capita) was added to estimated irrigation pumpage, under the assumption that a well served a household, but lawn and garden watering and other uses are accounted for with the irrigation pumpage. Average per capita pumpage for November-February is $154 \mathrm{gal} / \mathrm{d}$ for the non-municipal PWS systems that provided data. If the right also had FP or FR listed as a PRU, the 0.4 acre-ft also was assumed to account for these uses.

For rights with an additional PRU of ST (232 rights), the irrigation part of pumpage was previously estimated. A few of these rights appear to be only for stock-water use, but the majority has a reasonable amount of allowable irrigated acres, suggesting that most of the pumpage is for irrigation. Therefore, the irrigation pumpage estimate was assumed to be a base-level estimate for all rights with an associated ST use. Excluding rights with a PRU of ST, the irrigation pumpage estimate averaged about 69 percent of the appropriated right and had a standard deviation of 21 percent, whereas the rights with ST averaged 61 percent. Under the assumption that all ST rights use water for livestock, the base-level estimate was increased to 69 percent of the appropriated water.

One-hundred and forty-four rights had an additional PRU of DM, DG or MU. Pumpage for these rights greater than the base-level irrigation pumpage was estimated in two ways because these rights generally are in two categories. The first category is for water supplied to workers and the second category is water supply for households. The second category also included some rights that appear to supply public water, but they are not part of the Group A or B systems. The category for a right was estimated based on ownership, information from the drillers' log, and information on the appropriated values associated with the right.

For rights categorized as supplying drinking water for workers, $300 \mathrm{gal} / \mathrm{d}$ or 0.34 acre-ft was estimated as additional pumpage. The $300 \mathrm{gal} / \mathrm{d}$ is assumed to account for farm uses such as equipment cleaning. For the rights estimated to supply drinking water to multiple households, the average water duty was calculated for rights with a single PRU of IR. The amount of appropriated water greater than this average water duty (3.7 acre-ft/acre) was calculated. Based on a typical value of 1 acre-ft of appropriated water for a household, it was assumed that the remaining appropriated water greater than the average water duty represented the number of households. For example, 10 acre-ft remaining after applying the average 
water duty would represent 10 households. The estimated part of pumpage for drinking water supply for the right was then estimated as acre-ft available multiplied by the 0.4 acre-ft used for the DS estimates.

For rights with an additional PRU of HE and (or) CI, 50 percent of the appropriated quantity remaining after the irrigation, livestock, and domestic pumpage were subtracted was added as additional pumpage. For a single right with a PRU of DY, 80 percent of the remaining appropriated quantity was added. This right was associated with both irrigated crops and dairy operations. For the five rights with a PRU of EN and the two rights with a secondary PRU of RE, pumpage for these uses was assumed to be accounted for in the IR part.

A few but unknown number of standby/reserve rights may be supplemental for use in any year when the allowable withdrawal is met for the surface-water right. In addition, the lack of information about the allowable duty, on which rights are usable in any proratable year in contrast to drought/ emergency rights, on the different levels of prorating, and on the actual use of standby/reserve water makes it difficult to estimate the actual pumpage for the standby/reserve irrigation rights. Thus, standby/reserve pumpage was estimated using the same methods used for estimating primary pumpage. However, the estimated pumpage would be valid only during extreme prorating years (all rights are available and needed), and the estimated value would change by some factor depending on the prorating level. How the estimated standby/ reserve pumpage may change in prorating years is described in a following section that presents the estimates for the irrigation category.

Distribution of pumpage from any well over the irrigation season primarily depends on the particular crop or crops grown. In addition, soil moisture, pumping lift, and irrigation method also affect the temporal distribution of pumpage. To obtain a general understanding of the temporal distribution of irrigation pumpage, a simplified method was developed. Using this method, potential water needs of a crop type for each day in April through October, regardless of soil moisture content, were calculated for a 50-year period for 13 most commonly irrigated crops in the basin. For each crop type, the average percentage of total seasonal potential use for each month was then calculated. The 13 values were averaged for each month to derive an average percentage of total curve. The resulting average monthly percentages were then multiplied by total annual pumpage for 2000; pumpage was also separated by primary and standby/reserve rights. No weighting was done based on prevalence of a particular crop type in the basin. This distribution would be different for each crop type because of different plant water needs at different growth stages and the total amount of water pumped varies for a particular crop in the basin. For example, more apples are irrigated with ground water than beans, and the water needs and growing season differences between these two crop types are more than 1 acre-ft/acre. In addition, the curve does not represent pumpage in November for selected wine grapes. The distribution would also vary spatially for each year due to climatic factors, soil properties, and changing crop patterns. Thus, these curves represent a generalized or an effective distribution.

\section{Frost Protection}

Frost protection is instituted to protect fruit trees from frost damage during early emergence through budding. Frost protection was listed as a use for 209 water rights. Of these, 184 also had a PRU of IR. Of the remaining 25 water rights, 21 had FP as the only PRU and 4 had an additional PRU of either DS or DM. Frost protection accounts for only a small part of annual pumpage compared to irrigation pumpage for the rights with these PRUs; most of these rights have allowable irrigated acres typical of farms in the basin. Therefore, pumpage estimates for frost protection for the 184 rights were assumed to be accounted for in the irrigation estimates.

The 21 water rights with FP as the only PRU were associated with wells in an irrigation district, have a post-1976 priority date, or have a small annual appropriated value. Many of these wells also have a second right with a PRU of IR. The actual pumpage associated with FP from these wells that are either used only for frost protection or have a second right would be small compared to the other categories of uses, especially due to the fact that frost protection is not instituted very often; the average number of frost free days in the lower part of the basin, where most of the orchards are, is on the order of 180-200 days. Therefore, pumpage for these 21 rights, which total 356 acre-ft, was not estimated and is assumed to be either negligible or included in irrigation estimates for wells with a second right with a PRU of IR. These 21 rights account for less than one-tenth of 1 percent of the total appropriated annual quantity in the basin.

For the four rights with an additional PRU of either DS or DM, one was associated with a right for the same well with PRUs of IR and DS; therefore, the DS part was included as part of the right associated with irrigation use. Pumpage for the two rights with a PRU of DM, are included under the PWS estimates. The remaining right had a PRU of DS and the associated DS pumpage is included in the domestic right pumpage.

\section{Livestock}

There are 273 rights with a PRU of ST associated with them, which account for about 305 POWs. There were three classes, accounting for 68 POWs, of livestock rights for which ST was a principal PRU. The first is for the rights with a single PRU of ST, typically associated with dairy, ranching, and packing operations. Two other classes have an additional PRU of DM, DS, or CI/EN. The above three classes were assumed to have primary rights, even if the right is in an irrigation district because they do not have a PRU of IR. For these rights, 
the appropriated acre-ft right, typically 20-40 percent of the maximum instantaneous rate (in $\mathrm{gal} / \mathrm{min}$ ), was estimated as the pumpage. No additional pumpage was added for the other purposes because the full right was assumed to be used.

All remaining ST rights also have a PRU of IR with previously estimated irrigation pumpage. A few of these rights appear to be only for stock-water use, but most have a reasonable amount of allowable irrigated acres, suggesting that most of the pumpage is for irrigation. Pumpage estimates for these rights are not included as part of this category in order to retain the total estimated pumpage associated with a well and right. Additional pumpage for livestock use greater than the base-level irrigation estimate is included with a right associated with irrigation use. One ST right had an associated PRU of IR, but no allowable acreage; the pumpage estimate for this right was set to the appropriated value.

Also included under livestock pumpage is pumpage for rights associated with dairy operations. Fifteen rights had a PRU of DY, 10 of which also have a PRU of DS or DM. Dairies typically use their entire appropriated quantity (J. Kirk, Washington State Department of Ecology, written commun., 2005). Estimated pumpage for these rights also was set to the appropriated value. In addition, at least 19 smaller dairies currently operate using an exempt well. For these dairies, pumpage was estimated as the maximum allowed, 5,000 gal/d or 5.6 acre-ft. An approximate location for wells associated with these 19 dairies was estimated based on a dairy's address. Operations for most smaller dairies started in the late 1980s, which is consistent with the water-right priority dates for most dairies.

\section{Commercial and Industrial}

Pumpage estimates for this category principally are for 151 rights with a PRU of CI and (or) HE. Ten rights are without these PRUs, 6 have a principal PRU of RW, 2 have a PRU of FR (fire protection for 2 food processing plants), and 2 have a PRU of EN associated with industrial operations.

Pumpage was estimated for two subcategories using similar methods. The main subcategory includes all rights containing a PRU of CI, 3 rights with PRUs of HE and DM or DS, and the 10 rights described above. This subcategory has 118 rights with 143 POWs. Total maximum instantaneous rate for these rights is $29,429 \mathrm{gal} / \mathrm{min}$ and the annual quantity is 24,604 acre-ft. Six rights did not have an appropriated annual quantity in WRTS, which is needed to estimate pumpage. Based on the average ratio of instantaneous values to annual values for rights with similar instantaneous values, these 6 rights were estimated to account for an additional 784 acre-ft. The instantaneous rates for this subcategory ranged from 5 to $2,250 \mathrm{gal} / \mathrm{min}$ and averaged $251 \mathrm{gal} / \mathrm{min}$, and the annual quantity ranged from 2 to 2,024 acre-ft and averaged about 217 acre-ft.
Rights with a single PRU of CI account for 64 of the 118 rights in the first subcategory. In addition, 15 rights have an additional PRU of $\mathrm{HE}$ and 17 rights have an additional PRU of DG, DM, or DS. The remaining rights have various mixtures of PRUs. Two rights with smaller appropriated quantities also had a PRU of IR, but no allowable listed acreage; therefore, they are included as part of commercial and industrial pumpage.

The second subcategory contains rights with a single PRU of HE. Thirty-three rights had a single PRU of HE represented by 40 POWs. Rights with a PRU of $\mathrm{HE}$ are generally associated with heat pump use and (or) refrigeration and are considered commercial and industrial pumpage. The total maximum instantaneous rate for these rights is 6,682 $\mathrm{gal} / \mathrm{min}$ and the annual quantity is 6,219 acre-ft. Similar to the other subcategory, 7 rights had no listed annual quantity; to estimate an annual quantity an average ratio was calculated for the other 26 rights. Based on this ratio (0.94), these rights have an estimated annual quantity of about 720 acre-ft, and account for about 12 percent of the above total; note that one of the 7 rights had the same instantaneous value and use (heating and cooling of about the same size building) as another right and thus the ratio was not used to estimate the annual quantity but the annual value for the other right was assumed to be the best estimate for its right. The instantaneous rates for this subcategory ranged from 7 to $700 \mathrm{gal} / \mathrm{min}$ and averaged 202 $\mathrm{gal} / \mathrm{min}$; the annual quantity ranged from 1 to 960 acre-ft and averaged about 189 acre-ft.

Withdrawal information for this pumpage category was limited, with information available for only 13 rights. This lack of information was due to several factors, including one or some combination of: (1) owner did not know how much was withdrawn and no metering; (2) wells were no longer used for a component of the operations, such as heat exchange, resulting in unavailability of historical withdrawal information; (3) building was under new ownership or demolished and the right is no longer used; (4) owners were unaware of a well on the property and if there was a well, did not know when it was last used; and (5) owner-property-well could not be found (the well may no longer be in existence, but the end of use date is unknown).

Values provided ranged from about 0.2 to 137 percent of the right. Excluding the high value, the other values can be grouped into two categories: (1) a lower percentage category averaging about 4 percent and (2) an upper category averaging about 25 percent. The smallest ratio (0.2) is anomalous because its withdrawal is primarily representative of the second PRU of DG. This well serves a complex of non-industrial buildings and the PRU of CI could be related to older uses. In addition, a deep well on the property has a right to irrigate 500 acres and may provide water to any CI operations. The largest value (137) is for heat exchange 
of a large multi-story building and is atypical because the requirements of the building were not accounted for when obtaining the right; the withdrawals for this right are returned back to the ground-water system through an injection well. Values averaging 4 percent are related to either smaller operations or the right is primarily used for heating and cooling buildings. The lower values primarily are related to

$\mathrm{HE}$ uses and the 25 percent value applies to rights that include large-scale operations, including manufacturing and fruit and vegetable storage and processing. In addition, a value of 14 percent was obtained for an HE use that includes refrigeration for cold storage, and would be appropriately applied to such HE rights.

To estimate pumpage for the rights with no available information, a ratio (percentage of appropriated quantity) was assigned to each right and was then multiplied by the appropriated annual quantity. It was assumed that no water was withdrawn for fire protection for the 2 rights with a single PRU of FR. The types of operations and use of water for the 13 values described above, allowed for a reasonable assessment of which ratio to apply to which right.

For rights with a second PRU of DS, 0.40 acre-ft additional pumpage was added; the same value used for the irrigation category. For rights categorized as supplying drinking water for workers (PRU of DM or DG), $300 \mathrm{gal} / \mathrm{d}$ or 0.34 acre-ft was estimated as additional pumpage for the right.

Pumpage estimates for this category are for all 151 rights. A few of these rights are no longer used and withdrawals for additional rights may have also stopped. For these cases, the end date of use is not known. The authors chose to conservatively estimate that all wells were withdrawing water as of 2000 because during the entire estimated pumpage period (1960-2000) it was only towards the end that a few wells were no longer used.

\section{Fish and Wildlife Propagation}

Pumpage associated with fish and wildlife propagation principally is related to fish propagation, and in particular, for hatchery operations that account for most of the appropriated quantity and pumpage. Ten rights had PRUs of WL and FS, and data were available for 7 of the rights. Appropriated quantities for two remaining rights were smaller compared to the other rights; the larger rights have annual appropriated quantities on the order of 600 to 8,000 acre-ft. Based on the provided information, 90 percent of the appropriated quantity was used as the estimate for one of the rights without data that had a reasonable quantity associated with it. The other right is associated with a PRU of WL and serves a household, barn, and some fields that were obtained for wildlife. For this right, 3 acre-ft was presumed to be used based on property usage described by Washington State Fish and Wildlife (oral commun., 2005). One hatchery right was for supplemental use to surface-water sources, and according to Washington State Fish and Wildlife personnel, the well is no longer being used. No estimate was made for this right because it was unknown when it was used for supplemental supply and it has not been used for a reasonable period of time.

Pumpage values provided ranged from detailed values, from the start of use, to a daily and (or) annual value. For cases where only a daily value or annual value was provided, the value was assumed to be used for every year from the start of use.

In addition, information was available about the quantity pumped from two wells also used for hatchery operations. Although these wells do not have a right, they are accounted for under these categories because the wells are used for fish propagation and account for a reasonable amount of total pumpage for this category.

\section{Ground-Water Claims}

A water-right claim is a document declaring a claim for water use and may be valid if it describes a ground-water use before July 1945. Most claims were filed during an open filing period authorized by the 1967 Water Right Claims Registration Act or the 1998 reopening of the Act. Currently, a claim can be validated only through judicial processes involving filing applications, obtaining permits, and field inspections of the well in question. A favorable ruling results in the granting of a water right.

In 2005, about 16,605 ground-water claims were in effect in the Yakima River Basin (R. Dixon, Washington State Department of Ecology, written commun., 2004). Some of these claims were filed by well-owners who already have a right to use ground water. Other claims are for wells that do not require them. These wells may be covered under exempt status because they use 5,000 gal/d or less for stock watering, single or group domestic use, industrial use, or for lawns and commercial gardens of less than one-half acre. The basis of the analysis of claims was to estimate pumpage for claims that may not have been estimated in another pumpage category, and not to determine the validity of a claim.

WaDOE reduced the number of claims for which pumpage was estimated for this study through an office review of claims on file (J. Kirk, Washington State Department of Ecology, written commun., 2005). WaDOE first eliminated "short forms," using the reasonable assumption that the short form was most likely filed for wells that qualified as exempt wells and would be accounted for in the other pumpage estimates. This step reduced the number of claims to about 7,800.

Next, claims with a PRU of DG were eliminated. The same assumption was made for this step as used in the first. About 4,100 claims had a PRU of DG, yielding about 3,700 remaining claims. 
WaDOE then eliminated claims with two PRUs of DG and ST and (or) a single PRU of ST. The same assumption was used, as well as assuming that larger claims are accounted for in other pumpage (principally water-right) categories. Following this step, about 2,800 claims remained.

Last, WaDOE used the listed water source on the claim as a criterion for elimination. Some claims list tile drains, springs, creeks, sumps, lakes, and other surface-waters as sources. These were mistakenly filed as ground-water claims or were not considered surface-water sources during the ongoing adjudication process. Eliminating these claims reduced the number to 2,540 for analysis by USGS.

Project staff then analyzed each remaining claim based on location (TRS), PRU, annual claimed quantity, and the name associated with the claim. For each claim, the WRTS database was searched to determine if there was a matching right (PRU, quantity, and name) for the claim. If a matching right was found, the claim was eliminated under the assumption that the owner made an unnecessary claim for a valid right. If a match could not be found in WRTS, the digital well information files developed during this study and WaDOE's on-line database were searched by name and TRS for a well that could be associated with the claim. When a match was found and the well was relatively new or in some cases only post-1945, the claim was eliminated under the assumption that the claim was made on a ground-water use that was post-1945. These processes reduced the number of claims to 2,018 .

Next, 532 claims were eliminated because although they may have a listed PRU, there was no listing for the claimed quantity or acres irrigated. Without examining each original claim form, estimating pumpage for such a claim was impossible. Next, there were 451 claims that included a PRU of IR with listed allowable acres of 1 acre or less. Three-hundred and fifty of these claims had 2 PRUs of DG and IR or 3 PRUs of DG, IR, and ST. The remaining $101 \mathrm{had}$ a single PRU of IR. Based on the assumption that these claims may meet exempt status and would be accounted for in other pumpage categories, they also were eliminated. If these 451 claims did not meet exempt status, there might be on the order of 900 to 1,200 acre-ft of additional pumpage not accounted for by treating these claims as covered under the domestic exempt well category. Last, 2 claims were for a municipality whose pumpage is already accounted for under the PWS estimates, and these claims were eliminated. These processes reduced the number of claims to 1,033 .

The next step was to plot the well locations, which was supplied by WaDOE (J. Kirk, Washington State Department of Ecology, written commun., 2005), for the remaining claims because prior to 1945 , construction of water wells was primarily concentrated in certain areas. Plotting the location of the claims based on their PRU and acres irrigated thus allowed the project staff to estimate if additional claims could be eliminated. The resulting plot showed that the distribution of the remaining 1,033 claims was throughout the basin, indicating that it would be problematic to eliminate claims solely based on where they were located. A decision was made to examine claims with larger claimed irrigated acreage and a PRU of IR. For this final step, irrigated acres from the DOA's geodatabase in the TRS of the claim were compared to the claimed irrigated acreage to determine if the number of acres in the same section could account for the claimed acreage. If the claimed acreage was greater than the geodatabase acreage by some reasonable amount, then the claim was eliminated. For example, if the claimed acreage in a TRS was 160 acres and the geodatabase had identified only 1 field of 10 acres in the TRS, then the claim was eliminated. In contrast, if the geodatabase identified 2 fields, 1 of 70 acres and 1 of 60 acres, project staff assumed that together the acres approximated the claim and the claim was not eliminated. This last step assumes that the TRS for the claim is correct and that the geodatabase of irrigated fields is accurate. Based on this final step, the number of claims analyzed for pumpage was reduced to 924. Nine-hundred and sixteen of the remaining claims are principally for irrigation and stock use and the remaining 8 claims are principally for commercial and industrial uses. About 200 claims account for 75 percent of the total claimed irrigated acreage and only 80 claims account for about 50 percent of the total claimed acreage. No information exists on which well is associated with a particular claim because many wells usually are in the TRS of a claim. Therefore, the pumpage location is based on the center of the section identified in WRTS.

Pumpage was estimated for claims with irrigated acreage using the same methods used for estimating pumpage for the irrigation category. However, only 12 claims with irrigated acres listed the annual quantity. Water duty assigned to each claim was based on a crop type; therefore, unlike the irrigation category, the crop-water duty could be compared only to the claimed water-duty for the 12 claims to determine the smaller of the 2 water-duty values. Pumpage for 8 claims for commercial and industrial uses was estimated using the same method as used for the commercial and industrial category. Pumpage for the commercial and industrial part of these 8 claims was estimated as 25 percent of the annual quantity. For the 543 claims that also had a PRU of DG, it was assumed that this PRU was for supplying drinking water to workers, and about $300 \mathrm{gal} / \mathrm{d}$ or 0.34 acre-ft was estimated as additional pumpage. Not enough information was available to estimate the livestock use part of pumpage for the 249 irrigation claims that also had a PRU of ST because there was no claimed annual quantity. 


\section{Ground-Water Pumpage}

Ground-water pumpage was estimated for all water use categories. Depending on the pumpage category, the estimates are presented in either figures and (or) tables. PWS pumpage is not presented as a spatial distribution due to source-water security concerns. Unless stated otherwise, reported values are annual quantities. Pumpage estimates are presented as total annual quantities, such as irrigation pumpage in 2000, and the quantity of new pumpage in 1- or 5-year increments from 1960 to 2000. Annual pumpage also is presented as time series, at either 1- or 5-year time scales. Some category information is presented for earlier dates to more clearly highlight the growth in pumpage. When possible, pumpage estimates for the latest date, for example, 2004, are presented to provide a more current understanding of the total pumpage for selected categories. The presented estimates are those directly calculated using the methods described above, and thus, the estimates show significant figures to the ' 1 ' place. It should be understood that this does not imply the accuracy of the estimates but only the result of the calculations. Rounding of values to higher places makes it more difficult to reproduce both the estimates and values derived from using the described methods. Summation of values in some tables will not always equal the total values due to rounding to the ' 1 ' place. Pumpage for the frost protection category was assumed to be zero and is not described.

\section{Public Water Supply}

Pumpage from municipal (Group A) systems steadily increased from 1960 to 2000 (fig. 12; table 2), ranging from about 19,127 acre-ft (17.1 Mgal/d or $6.22 \mathrm{Bgal})$ in 1960 to about 37,273 acre-ft (33.3 Mgal/d or 12.2 Bgal) in 2000 . Other Group A and B water systems also exhibited steadily increasing pumpage at proportionately similar rates. Estimated pumpage from Group A and Group B systems ranged from about 3,888 acre-ft (3.47 Mgal/d or $1.27 \mathrm{Bgal})$ and $858 \mathrm{acre}-\mathrm{ft}$ $(0.77 \mathrm{Mgal} / \mathrm{d}$ or $0.28 \mathrm{Bgal})$, respectively, in 1960 to about $7,465 \mathrm{acre}-\mathrm{ft}(6.67 \mathrm{Mgal} / \mathrm{d}$ or $2.43 \mathrm{Bgal})$ and $1,650 \mathrm{acre}-\mathrm{ft}$ $(1.47 \mathrm{Mgal} / \mathrm{d}$ or $0.54 \mathrm{Bgal})$, respectively, in 2000 . Groundwater pumpage increases for the PWS systems mirrored population increases and the rates of increases are similar to the rates of increases for municipal systems that provided several years of data.

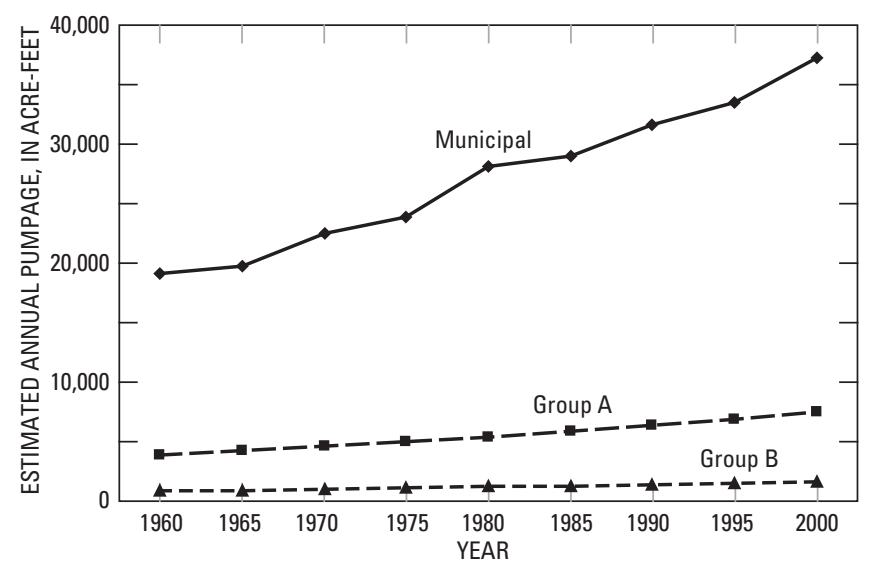

Figure 12. Estimated annual pumpage for public water supply, Yakima River Basin, Washington, 1960-2000.

Table 2. Estimated annual pumpage for public water supply, Yakima River Basin, Washington, 1960-2000.

[All values are in acre-feet]

\begin{tabular}{lrrrrrrrrr}
\hline \multirow{2}{*}{ Public water supply } & \multicolumn{8}{c}{ Pumpage } \\
\cline { 2 - 10 } & $\mathbf{1 9 6 0}$ & $\mathbf{1 9 6 5}$ & $\mathbf{1 9 7 0}$ & $\mathbf{1 9 7 5}$ & $\mathbf{1 9 8 0}$ & $\mathbf{1 9 8 5}$ & $\mathbf{1 9 9 0}$ & $\mathbf{1 9 9 5}$ & $\mathbf{2 0 0 0}$ \\
\hline & \multicolumn{7}{c}{ Municipal systems } \\
\hline Group A water systems & 19,127 & 19,755 & 22,457 & 23,836 & 28,072 & 29,047 & 31,661 & 33,454 & 37,273 \\
\hline & \multicolumn{7}{c}{ Other systems } \\
\hline Group A water systems & 3,888 & 4,219 & 4,577 & 4,966 & 5,388 & 5,846 & 6,432 & 6,881 & 7,465 \\
Group B water systems & 858 & 931 & 1,010 & 1,095 & 1,188 & 1,289 & 1,399 & 1,518 & 1,647 \\
\cline { 2 - 11 } Total & 23,873 & 24,905 & 28,044 & 29,897 & 34,648 & 36,182 & 39,492 & 41,853 & 46,385 \\
\hline
\end{tabular}


PWS pumpage distribution closely follows the population distribution shown in figure 11. In Kittitas County, most PWS systems are near Interstate 90 and in resort areas in the Cascade Range foothills. In Yakima and Benton Counties, most Group A and B wells are near Interstate 82 and to a lesser extent, along the Naches, Tieton, and Bumping Rivers.

The monthly distribution of total annual pumpage in 2000 (fig. 13) shows that the maximum pumpage was in July (about 6,430 acre-ft), closely followed by August at about 6,350 acre-ft. Together, these months account for nearly 30 percent of the annual pumpage. Minimum pumpage for PWS was in February (about 2,200 acre-ft) and the pumpage in December was about the same. Pumpage in July was nearly 3 times more than in February, primarily due to lawn and garden watering during the summer growing season. The shape of the curve is similar, including the slight upturn in January, to previously reported values for the study area (Kinnison and Sceva, 1963; Parker, 1971).

\section{Domestic}

The self-supplied pumpage in Benton, Kittitas, and Yakima Counties, for domestic use increased by about 8,000 acre-ft from 1960 to 2000 (fig. 14, table 3). In 1960, pumpage totaled about $12,400 \mathrm{acre}-\mathrm{ft}(11.2 \mathrm{Mgal} / \mathrm{d}$ or $4.03 \mathrm{Bgal})$ and by 2000 , had nearly doubled to about 20,000 acre-ft (17.9 $\mathrm{Mgal} / \mathrm{d}$ or $6.52 \mathrm{Bgal}$ ), equivalent to a basin-wide average per capita rate of about $180 \mathrm{gal} / \mathrm{d}$. However, pumpage decreased in Benton and Kittitas Counties during several 5-year intervals. The decreases for Kittitas and Benton Counties were due to decreases in population and the establishment of numerous PWS systems. Although some PWS systems may have been operating prior to a decreasing interval, the start year estimate is based on the "effective source date" obtained from the database provided by DOH.

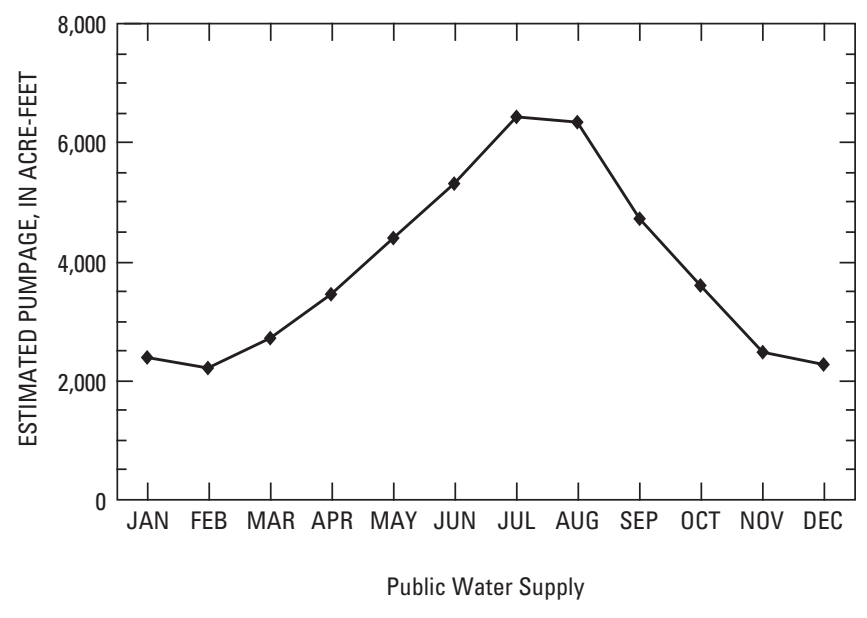

Figure 13. Estimated monthly distribution of annual pumpage for public water supply, Yakima River Basin, Washington, 2000.

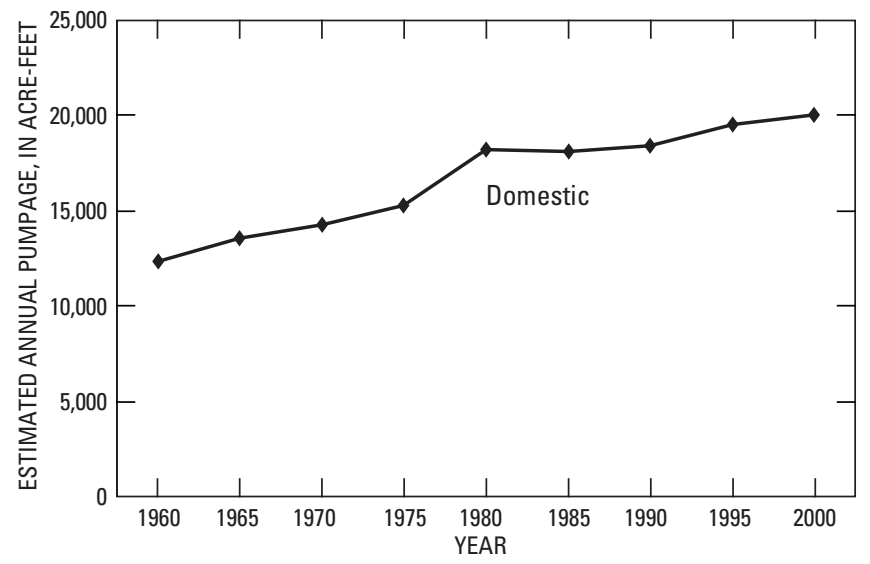

Figure 14. Estimated annual pumpage for domestic use, Yakima River Basin, Washington, 1960-2000.

Table 3. Estimated annual pumpage for domestic use, Yakima River Basin, Washington, 1960-2000.

[All values are in acre-feet]

\begin{tabular}{rrrrrrrrrr}
\hline County & \multicolumn{8}{c}{ Pumpage } \\
\cline { 2 - 10 } & $\mathbf{1 9 6 0}$ & $\mathbf{1 9 6 5}$ & $\mathbf{1 9 7 0}$ & $\mathbf{1 9 7 5}$ & $\mathbf{1 9 8 0}$ & $\mathbf{1 9 8 5}$ & $\mathbf{1 9 9 0}$ & $\mathbf{1 9 9 5}$ & $\mathbf{2 0 0 0}$ \\
\hline Benton & 1,392 & 1,367 & 1,769 & 1,818 & 2,920 & 2,374 & 2,313 & 2,619 & 2,751 \\
Kittitas & 1,248 & 1,375 & 1,249 & 1,066 & 1,494 & 1,518 & 1,706 & 2,085 & 2,328 \\
Yakima & 9,739 & 10,824 & 11,264 & 12,385 & 13,770 & 14,185 & 14,362 & 14,853 & 14,957 \\
\cline { 2 - 10 } Totals & 12,379 & 13,566 & 14,282 & 15,270 & 18,184 & 18,077 & 18,382 & 19,557 & 20,036 \\
\hline
\end{tabular}


Yakima County, the most populous county, had the most domestic pumpage in the study area, ranging from about 9,739 acre-ft (8.7 Mgal/d or 3.17 Bgal) in 1960 to about 14,957 acre-ft (13.4 Mgal/d or 4.89 Bgal) in 2000 (table 3). In 2000, pumpage in Yakima County accounted for some 75 percent of the total domestic pumpage. Pumpage in the least populated county, Kittitas County, ranged from about 1,250 acre-ft (1.12 Mgal/d or 0.41 Bgal) in 1960 to about 2,330 acre-ft (2.08 Mgal/d or 0.76 Bgal) in 2000 (table 2). Pumpage in Benton County ranged from about 1,390 acre-ft (1.24 Mgal/d or $0.45 \mathrm{Bgal}$ ) in 1960 to about 2,750 acre-ft (2.46 Mgal/d or $0.9 \mathrm{Bgal})$ in 2000. Nearly all of the domestic pumpage is accounted for by the exempt wells. It is estimated that, of the total estimated pumpage in 2000 of 20,036 acre-ft, only about 31 acre-ft was for the 63 rights with a single PRU of DS. Self-supplied domestic pumpage for rights with additional PRUs was about 322 acre-ft, and this pumpage is included in either the irrigation, commercial and industrial, or livestock categories.

The spatial distribution of domestic pumpage for 2000 (fig. 15) is based on census block population and calculations described in Methods. Areas with the most pumpage are areas with the greatest number of people. There were 3,719 census blocks with 99,078 people who obtained water from exempt wells and from the 63 domestic wells with water rights. The census block population ranged from 1 to 540 per block. Based on the self-supplied population per block and the average number of people per household for each block, an estimate was derived of the number of houses per block served by exempt wells. The total number of houses indicates that about 43,100 wells supply water for domestic pumpage.

\section{Irrigation}

Irrigation rights typically are for withdrawals from April 1 to October 30. Pumpage for other PRUs associated with an irrigation right are assumed to be constant throughout the year. Excluding PWS rights for irrigation and irrigation pumpage for ground-water claims, the total estimated pumpage in 2000 for primary and standby/reserve rights was about 271,042 acre-ft (242 Mgal/d or 88.3 Bgal), of which about 188,230 acre-ft (168 Mgal/d or $61 \mathrm{Bgal})$ was estimated to be associated with primary rights (table 4). Other uses associated with irrigation rights account for only about 3 percent of the total or about 7,838 acre-ft $(7.5 \mathrm{Mgal} / \mathrm{d}$ or 2.7 Bgal). However, as will be shown later, the total pumpage for these other uses is larger than both the self-supplied commercial and industrial uses and livestock uses.

The spatial distribution of irrigation pumpage (fig. 16) shows that pumpage tends to be concentrated in the mid-tolower parts of the basin, especially in the Wenas Creek Valley, lower Naches River area, Moxee City area, and Ahtanum Creek Valley (fig. 1). Other pumpage was concentrated along the south slope of Rattlesnake Hills, the lower part of Benton County, and in valleys extending eastward from Moxee City.

About 75 percent $(204,500$ acre-ft) of the total estimated annual pumpage was in Yakima County and about 70 percent of the total was for primary rights. Pumpage in Benton County was about 60,200 acre-ft (about 23 percent of the total) and about 67 percent was for primary rights. In comparison, Kittitas County had the smallest allowable acreage $(2,806$ acres) and the smallest amount of estimated pumpage, about 6,310 acre-ft, 94 percent of which was for primary rights.

Table 4. Estimated annual pumpage for irrigation water rights, Yakima River Basin, Washington, 2000.

[Values in parentheses include 1,567 acre-feet of pumpage added from 2001 through 2003. Standby/reserve: Estimates based on pumpage occurred in all years and is not the actual pumpage; pumpage occurred only in 1977, 1979, 1987, 1988, 1992, 1993, and 1994. All values are in acre-feet]

\begin{tabular}{lccc}
\hline $\begin{array}{c}\text { Water rights } \\
\text { category }\end{array}$ & $\begin{array}{c}\text { Total estimat- } \\
\text { ed pumpage }\end{array}$ & $\begin{array}{c}\text { Irrigation pump- } \\
\text { age }\end{array}$ & Other uses \\
\hline All rights & 271,042 & 263,204 & 7,838 \\
& $(272,608)$ & $(264,770)$ & $(7,838)$ \\
Primary & 188,320 & 181,336 & 6,894 \\
& $(189,602)$ & $(182,708)$ & $(6,894)$ \\
Standby/reserve & 82,812 & 81,868 & 944 \\
& $(83,006)$ & $(82,062)$ & $(944)$ \\
\hline
\end{tabular}




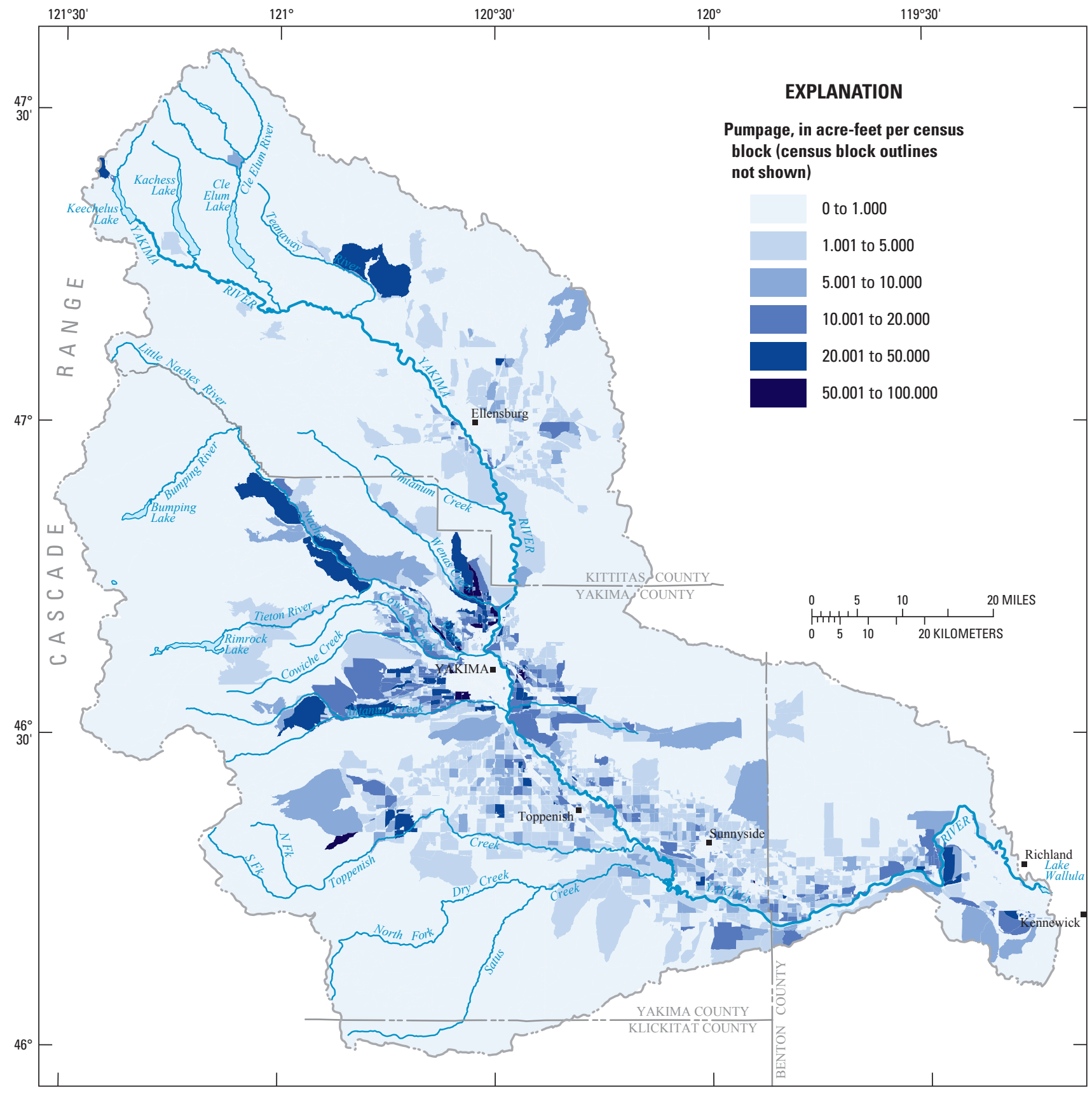

Figure 15. Distribution of estimated annual pumpage for domestic use, Yakima River Basin, Washington, 2000. 


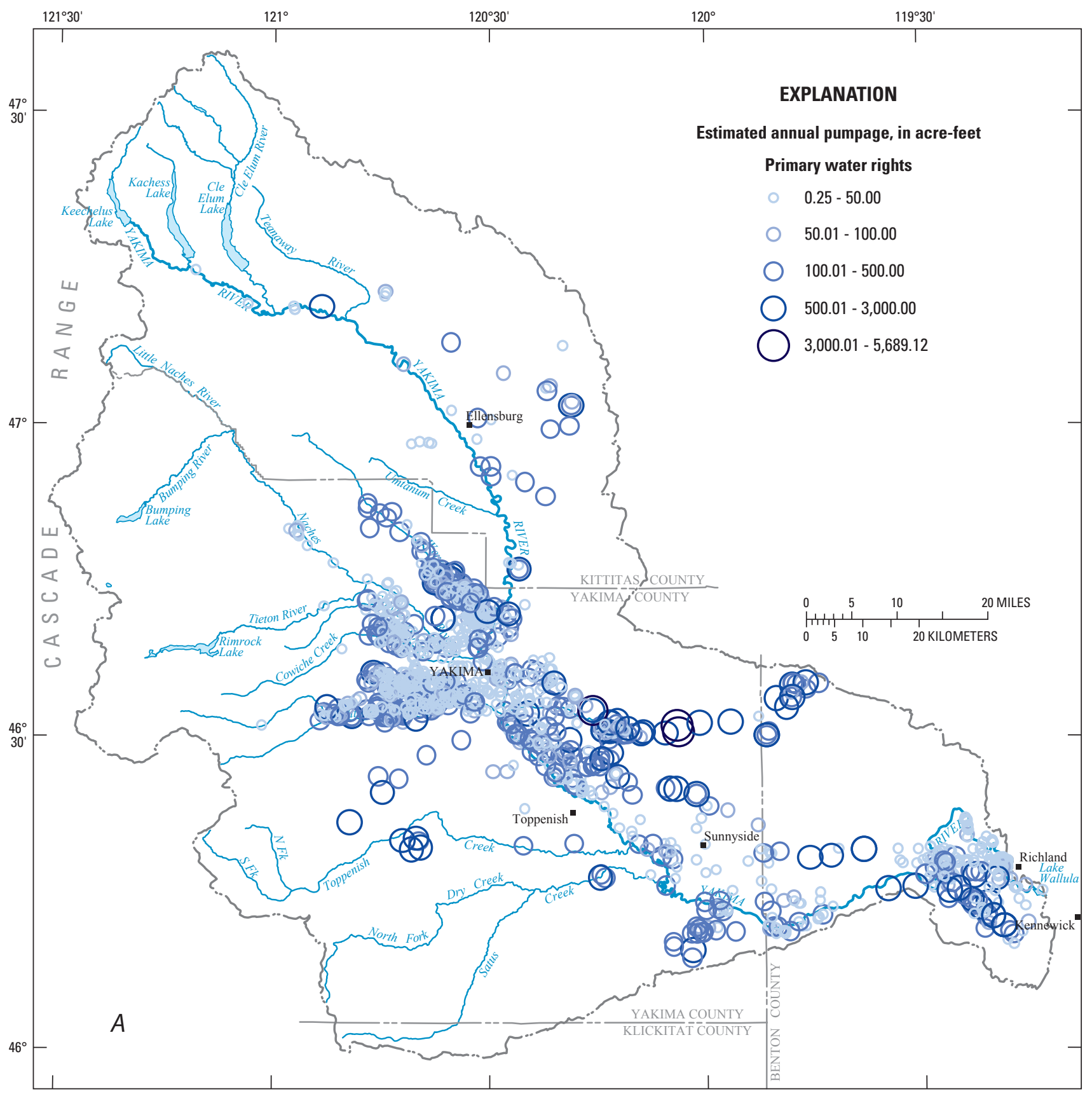

Figure 16. Distribution of estimated annual pumpage for irrigation, Yakima River Basin, Washington, 2000. 


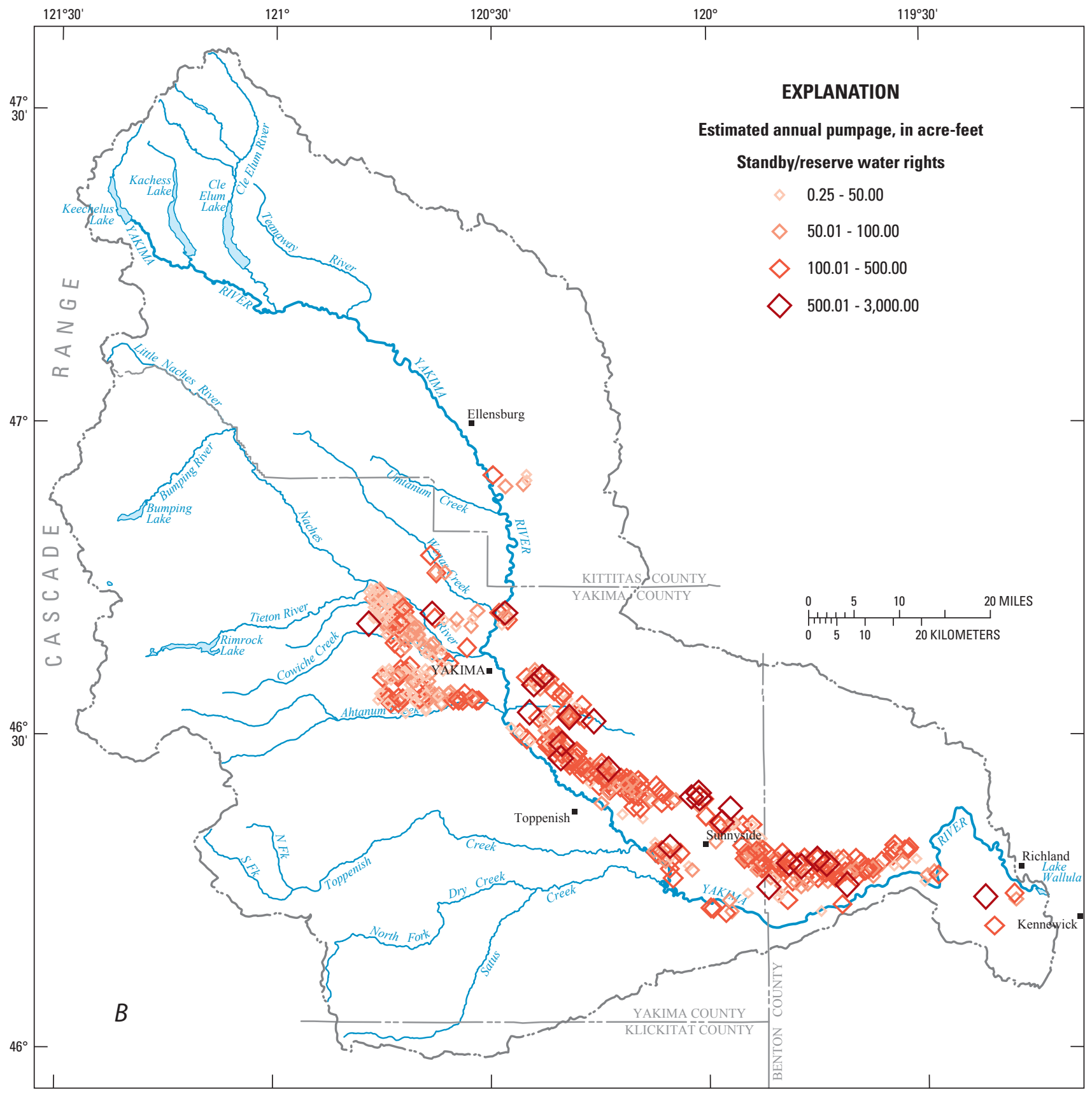

Figure 16.-Continued. 
Annual pumpage increased inconsistently over time (fig. 17; table 5). Annual pumpage was about 42,000 acre-ft in 1959 and increased to about 271,042 acre-ft by 2000 (tables 4,5 ). New pumpage added from 2000 to 2003 was estimated to be only 1,567 acre-ft. Since 2003 (excluding new pumpage during the 2005 drought), an additional small amount of pumpage was also added because ground water has been exchanged for surface water (a change in source for a water right) as part of projects for increasing instream flows in small streams. Except for 1975-79, total new pumpage (primary and standby/reserve) generally increased by about 10,000 to 29,000 acre-ft per 5 year increment from 1960 through 1994 (table 5). Between 1975 and 1979, the total estimated irrigation pumpage added was nearly 100,000 acre-ft due to the granting of new water-rights with large allowable annual quantities. However, about one-half of this new pumpage was due to standby/reserve pumpage associated with rights that started during the 1977 drought. After 1979, the amount of new primary pumpage added continually decreased through 2000. From 1995 through 2000, irrigation pumpage increased only by about 3,600 acre-ft (table 5), which is about the total increase from the 1890s through 1919 and the increase in the 1930s (data not shown).
Table 5. Estimated irrigation pumpage, by primary and standby/ reserve water rights, in 5-year increments, Yakima River Basin, Washington, 1960-2000.

[Years: 1890 is the first year for irrigation pumpage associated with water rights. Estimates for total pumpage added prior to 1960 and after 2000 also are shown. Standby/reserve: Estimates based on pumpage occurred in all years and is not the actual pumpage; pumpage occurred only in 1977, 1979, 1987, 1988, 1992, 1993, and 1994. All values in acre-feet]

\begin{tabular}{lccc}
\hline \multicolumn{3}{c}{ Years } & \multicolumn{3}{c}{ Pumpage } \\
\cline { 2 - 4 } & $\begin{array}{c}\text { Estimated pump- } \\
\text { age added }\end{array}$ & New primary & $\begin{array}{c}\text { New standby/ } \\
\text { reserve }\end{array}$ \\
\hline 1890-1959 & 42,000 & 41,896 & 104 \\
$1960-64$ & 9,299 & 9,299 & 0 \\
$1965-69$ & 20,271 & 20,249 & 22 \\
$1970-74$ & 25,010 & 23,743 & 1,267 \\
$1975-79$ & 99,474 & 49,399 & 50,075 \\
$1980-84$ & 28,845 & 17,507 & 11,338 \\
$1985-89$ & 20,687 & 14,927 & 5,760 \\
$1990-94$ & 21,821 & 10,398 & 11,423 \\
$1995-2000$ & 3,635 & 812 & 2,823 \\
2001-03 & 1,567 & 1,373 & 194 \\
\hline
\end{tabular}

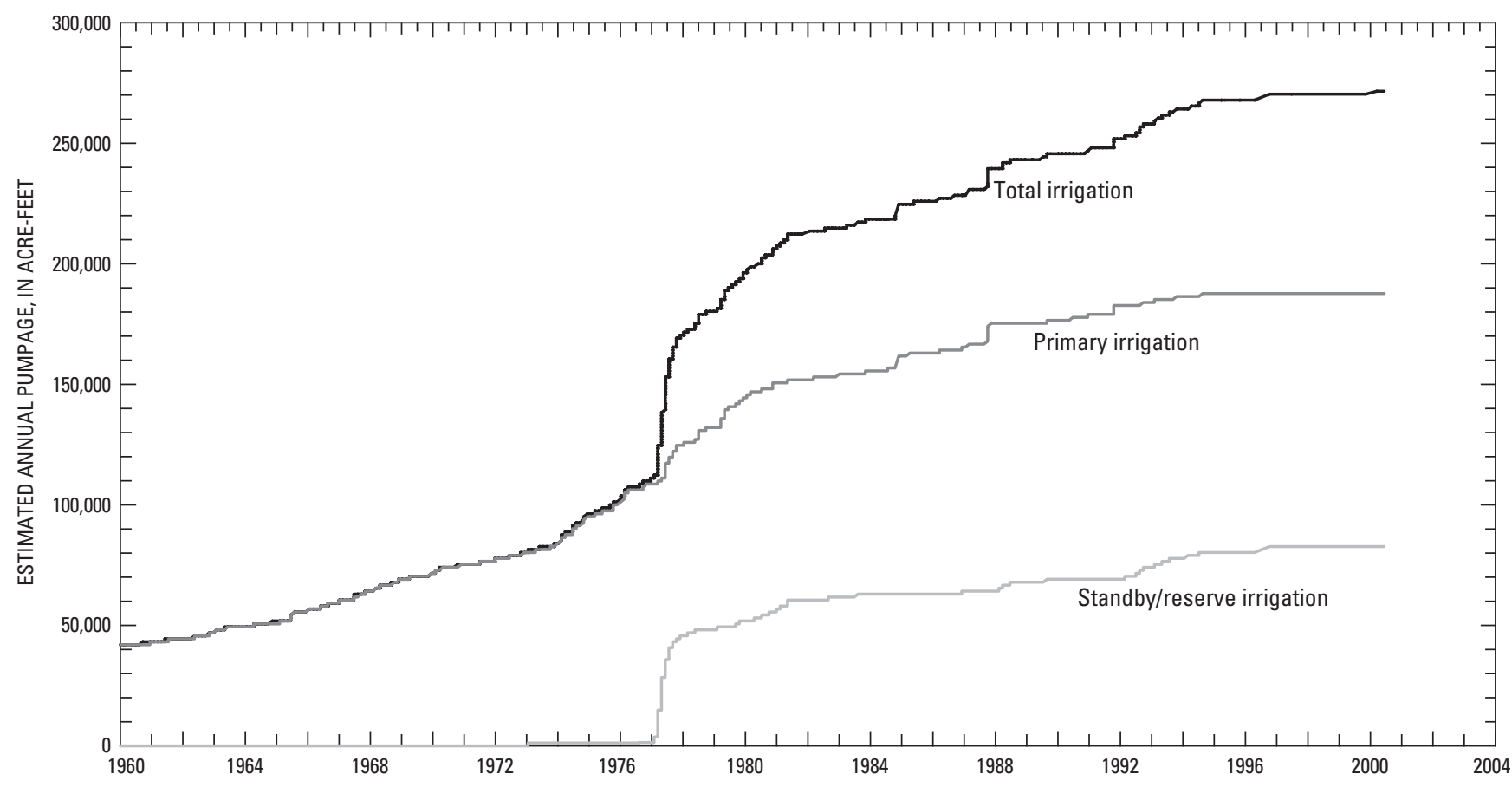

Figure 17. Estimated annual irrigation pumpage, Yakima River Basin, Washington, 1960-2000. 
The generalized monthly distribution of irrigation pumpage for 2000 (fig. 18) shows a maximum in July and a minimum in October (November pumpage for a few vineyards is not included in the generalized distribution). More than 70 percent of the pumpage occurs June through August. If all standby/reserve rights were used in a dry year, then some 80,000 acre-ft may be withdrawn in July, and if no water was withdrawn for standby/reserve use, then the July total would be about 56,000 acre-ft.

\section{Standby/Reserve Irrigation Pumpage}

Standby/reserve pumpage estimates are based on the crop-water duty and the appropriated right, that is, standby/ reserve rights were treated the same as primary rights. The standby/reserve estimates are representative of the amount of water that can be withdrawn under the right with the identified crops, as if every year was an extreme drought year. These estimates are not actual withdrawal rates, but represent the amount of water that may be withdrawn. Total pumpage in any year is dependent on the prorated amount, if any, during an irrigation season. For years with no prorating, the total irrigation pumpage for standby/reserve rights would be zero and the irrigation pumpage estimate would be the primary pumpage. For years with prorating, standby/reserve pumpage would occur at some percentage of the estimated value; the percentage would depend on the prorated amount. Therefore, the actual pumpage for standby/reserve irrigation rights for prorating years is difficult to estimate. The type of standby/ reserve right for each right would need to be identified, as well as the actual allowable quantity, not necessarily the listed value in WRTS. To obtain a potential pumpage

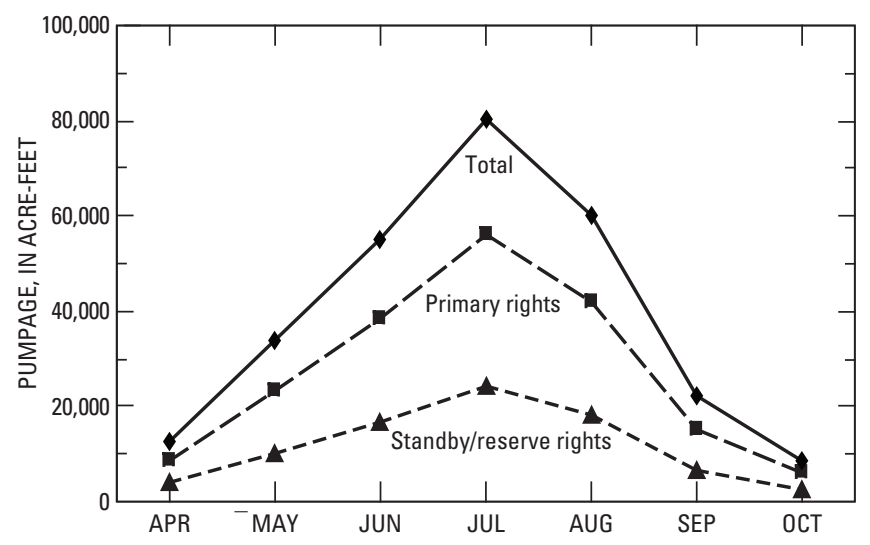

Figure 18. Generalized monthly distribution of irrigation pumpage during the irrigation season, Yakima River Basin, Washington, 2000. estimate associated with standby/reserve rights in a prorating year, multiplication factors based on prorating levels were estimated. This information also is needed for other work elements.

For the 2001 drought, 64 emergency rights (a type of a standby/reserve right for emergency use) reported an actual use of 2,499 acre- $\mathrm{ft}$ with an authorized amount of 9,073 acre- $\mathrm{ft}$ (R. Dixon, Washington State Department of Ecology, written commun., 2003). The use was listed as zero for 32 wells because meters were missing or broken, wells were never completed or were being drilled, no data were provided, or no pump was installed. Using only actual usage information for the other 32 rights, yields an appropriated quantity of 4,702 acre-ft; on average, about 53 percent of the appropriated value was used. Based on water-right files, the allowable acres for 9 of these rights were determined. The water duty averaged about 1 acre-ft/acre and ranged from 0.2 to 2.8 acre-ft/acre. Assuming that the 53 percent value (compared to this study's estimate that 79 percent of appropriated water is withdrawn) is a reasonable approximation for standby/reserve pumpage during drier years $(1994,2001$, and 2005) with the most prorating, the pumpage estimates for the standby/reserve rights may be as much as 26 percent too large in drier years.

Pumpage in prorating years is similar to multiplying the estimated standby/reserve pumpage by the prorating appropriated percentage, that is, a 37 percent proratable entitlement yields 63 percent (a multiplication factor) of the estimated pumpage as an annual value. For example, the 37 percent prorating in 1994 suggests that the standby/reserve estimate of about 80,000 acre-ft would be reduced to about 50,400 acre-ft as the estimate of the standby/reserve pumpage for 1994. For years with the least prorating, the prorating ranged from 80 to 88 percent of appropriated surface-water value, and there was minimal standby/reserve pumpage. Therefore, a reasonable assumption is that at some base prorating level, say, 88 percent (the prorating in 1988), some small level of standby/reserve pumpage would be initiated, probably on the order of 5 percent, and would be zero for prorating percentages greater than 88 . Between about 70 to 75 percent prorating (30 to 25 percent multiplication factors), multiplication factors would likely decrease linearly to about 5 percent at the 88 percent prorating level and would be zero after 88 percent.

The standby/reserve rights with a water duty on the order of 0.1 to nearly 1 acre-ft/acre would likely be completely used in most years with prorating levels of about 80 to 88 percent. The latter is especially true for perennial crops, such as orchards. For example, of the 32 rights with data, 9 had older existing standby/reserve rights, suggesting the full quantity of the older right was to be used and the application was for additional emergency water. Most of these 9 rights 
were for orchards, and the irrigation of such perennial crops is important. This suggests that standby/reserve pumpage values estimated using multiplication factors as described above may be conservatively low.

\section{Livestock}

Pumpage for livestock uses, as defined in this report, is primarily for stock watering and dairy operations. Livestock pumpage associated with an irrigation right for irrigating pasture and (or) crop lands is included as part of the irrigationpumpage estimates. Estimates presented principally are for wells with rights for livestock use (about 63 rights) and are based on the full appropriated quantity. In addition, 19 small dairies that pump water under an exempt status are accounted for.

The estimated pumpage for livestock in 2003 was 7,010 acre-ft (6.3 Mgal/d or 2.3 Bgal), table 6. About 1,840 acre-ft $(0.6 \mathrm{Bgal})$ is for dairy operations based on the PRU of DY. However, several livestock rights without a PRU of DY also are for dairy use and total about 280 acre-ft; the PRU of DY was not established at the time of the right. The increasing pumpage is shown in figure 19. Early in 1960, about 222 acre-ft was pumped, and by 1969 this pumpage increased to only about 469 acre-ft (table 6). The largest increase in new livestock pumpage (about 3,189 acre-ft) was during 1970-74 (table 6) and is associated with new water-rights with large allowable annual quantities. By 1984, the pumpage had increased to 4,738 acre-ft, and there was a large increase during 1990-94; total pumpage by 1994 was about 6,726 acre-ft. No increase occurred through 2000, with some increase in 2002 for dairy operations. Thus, the estimated pumpage increased from 222 acre-ft at the beginning of 1960 to 6,726 acre-ft in 2000 , with an additional 284 acre-ft of pumpage added in 2002.

Table 6. Estimated annual pumpage for livestock use in 5-year increments, Yakima River Basin, Washington, 1960-2000.

[Years: 1914 is the first year for livestock pumpage associated with water rights. Pumpage: Pumpage does not include livestock use associated with irrigation rights. Pumpage listed is for new quantities added in each 5-year increment and cumulative totals. Estimates for total pumpage added during the years prior to 1960 and after 2000 are also shown. All values in acre-feet]

\begin{tabular}{lrc}
\hline \multicolumn{2}{c}{ Years } & \multicolumn{2}{c}{ Pumpage } \\
\cline { 2 - 3 } & $\begin{array}{c}\text { Estimated pumpage } \\
\text { added }\end{array}$ & Cumulative \\
\hline $1914-59$ & 222 & 222 \\
$1960-64$ & 208 & 430 \\
$1965-69$ & 39 & 469 \\
$1970-74$ & 3,189 & 3,658 \\
$1975-79$ & 84 & 3,742 \\
$1980-84$ & 996 & 4,738 \\
$1985-89$ & 461 & 5,199 \\
$1990-94$ & 1,527 & 6,726 \\
$1995-2000$ & 0 & 6,726 \\
$2001-03$ & 284 & 7,010 \\
\hline
\end{tabular}

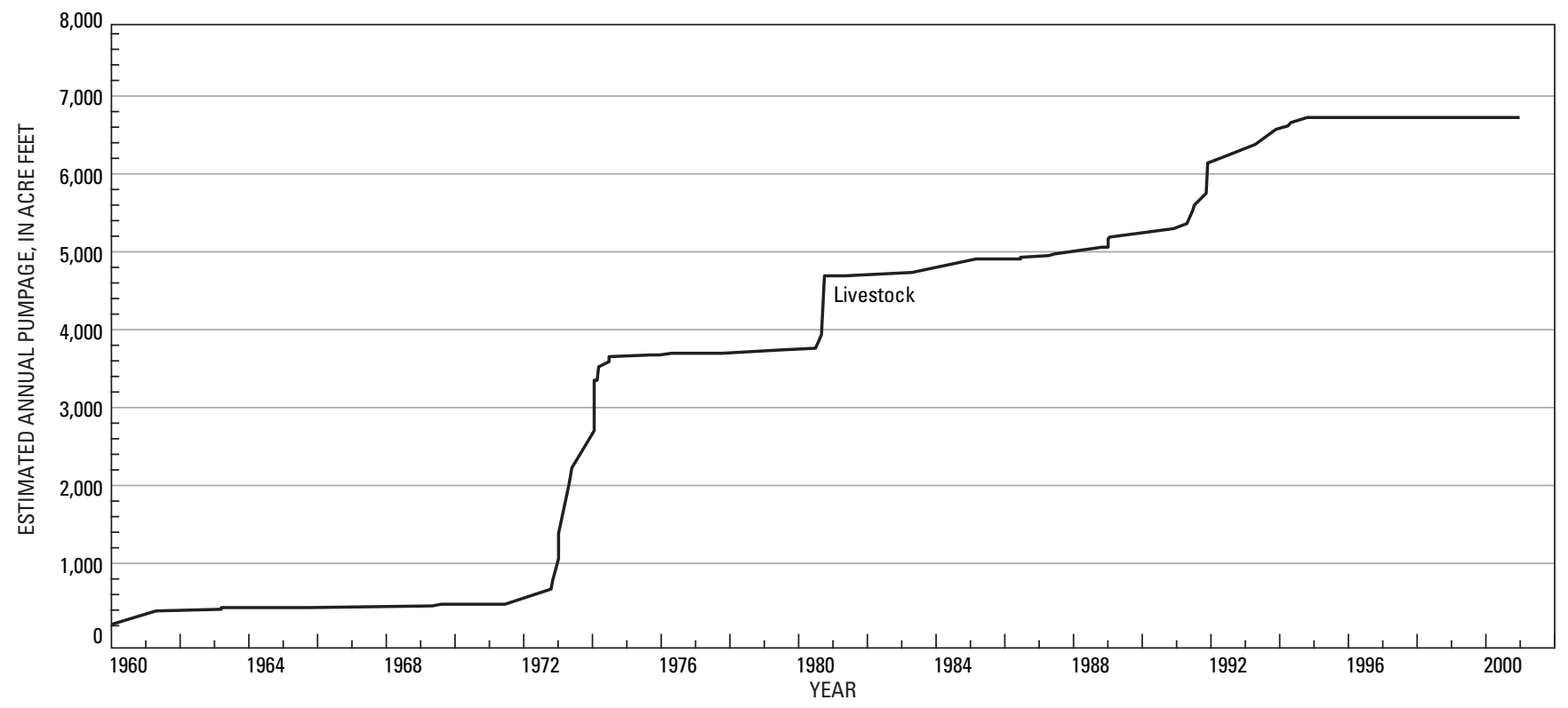

Figure 19. Estimated annual pumpage for livestock use, Yakima River Basin, Washington, 1960-2000. 
The spatial distribution of livestock pumpage (fig. 20) shows that most pumpage is concentrated on the south slope of the Rattlesnake Hills and along the stretch from Granger through Mabton and Prosser. Additional pumpage is in the Ahtanum Creek valley and the Moxee City area, and about 210 acre-ft of pumpage is in the Kittitas basin. Overall, total pumpage for livestock (without irrigation rights) and dairy operations accounts for less than 3 percent of total pumpage in the basin. However, livestock rights with another PRU of IR have about 5,166 acre-ft of pumpage accounted for in the irrigation pumpage category.

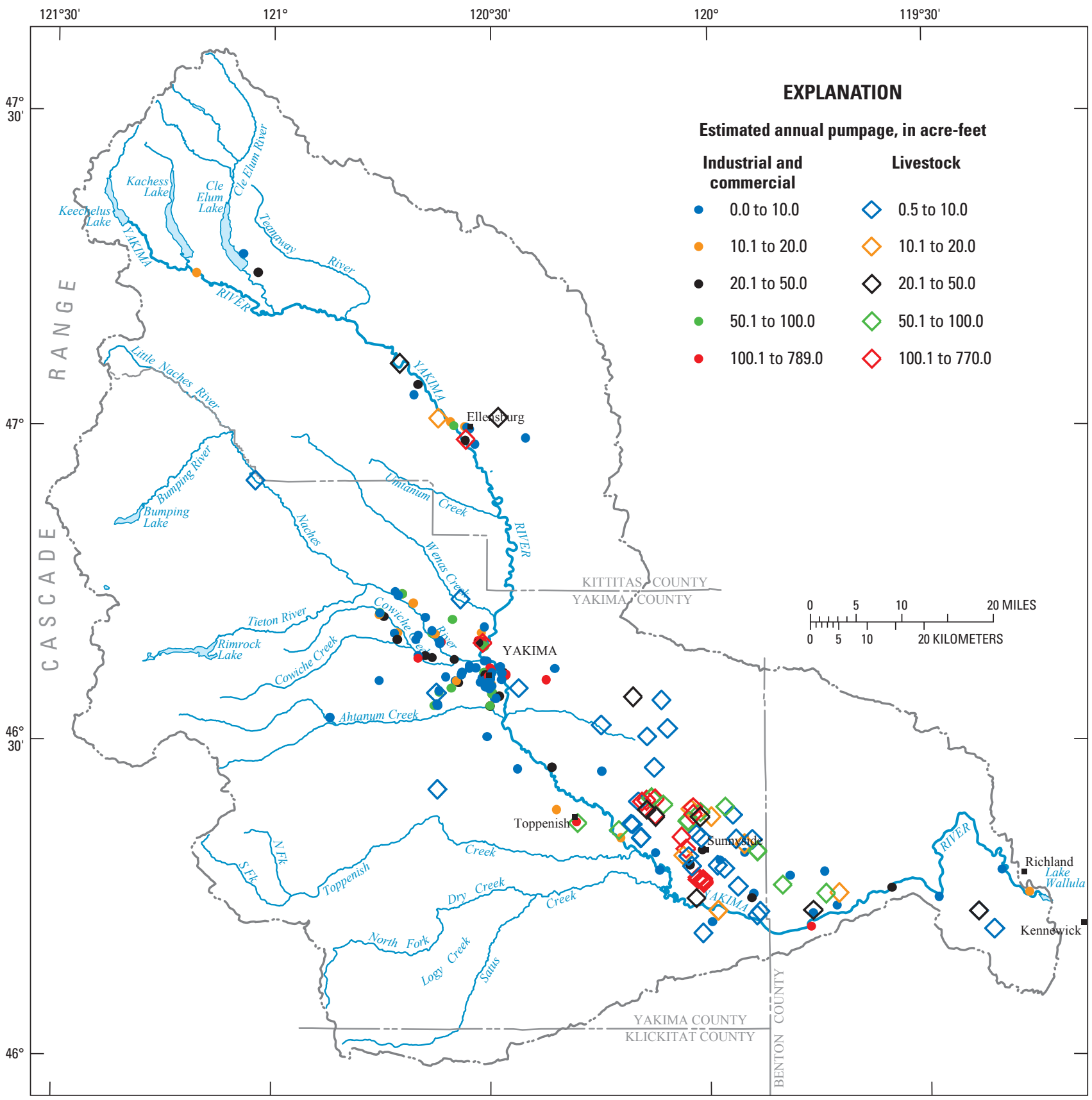

Figure 20. Distribution of estimated annual pumpage for livestock and commercial and industrial uses, Yakima River Basin, Washington, 2000. 


\section{Commercial and Industrial}

The commercial and industrial category includes pumpage for heat exchange, refrigeration, food and timber processing, railway, manufacturing, and other industrial uses. Pumpage was estimated for 151 ground-water rights with PRUs that are primarily associated with the above uses. Total estimated pumpage in 2000 was about 7,230 acre-ft (6.5 Mgal/d or $2.3 \mathrm{Bgal}$ ) (table 7). However, actual pumpage probably decreased by some small amount. From the dates of rights and drilling of wells, estimated pumpage was about 14 percent (1,042 acre-ft) of the 2000 total prior to 1930 , and by 1959, 3,093 acre-ft (about 43 percent of the 2000 total) was already being withdrawn for commercial and industrial uses. Since 1960, estimated pumpage increased by 4,137 acre-ft, with no new pumpage added after 1992. The largest pumpage increase was during 1965-69 and 1980-89, and the largest single year increase was in 1981 at 1,080 acre-ft (fig. 21).

The spatial distribution of commercial and industrial pumpage (fig. 20) shows that most pumpage is concentrated in the Ahtanum Creek valley and the Moxee City area (fig. 1). Other pumpage is concentrated near the Yakima River in the area between Toppenish and Prosser. Other pumping centers are in the lower part of the Naches River Basin and in the Kittitas basin near the City of Ellensburg.

A simplified method was developed to obtain a general understanding of the temporal distribution of pumpage. In this method, we assumed two basic pumpage categories: (1) food products and (2) all other uses. The first category represents about 76 percent of the total and the second category accounts for the remaining 24 percent. A monthly percentage of annual pumpage was calculated from information in Dion and Lum (1977) for the Standard Industrial Classification for Food and Kindred Products, which generally represent the first category. The monthly percentage of annual pumpage was assumed to be constant throughout the year for the second

Table 7. Estimated annual pumpage for commercial and industrial uses in 5-year increments, Yakima River Basin, Washington, 1960-2000.

[Years: 1917 is the first year for commercial and industrial pumpage associated with water rights. Pumpage: Pumpage listed is for new quantities added in 5-year increments and cumulative totals. Estimates for total pumpage added during the years prior to 1960 are also shown. All values in acre-feet]

\begin{tabular}{|c|c|c|}
\hline \multirow[b]{2}{*}{ Years } & \multicolumn{2}{|c|}{ Pumpage } \\
\hline & $\begin{array}{c}\text { Estimated pumpage } \\
\text { added }\end{array}$ & Cumulative \\
\hline $1917-59$ & 3,093 & 3,093 \\
\hline 1960-64 & 438 & 3,531 \\
\hline $1965-69$ & 1,428 & 4,959 \\
\hline $1970-74$ & 612 & 5,571 \\
\hline $1975-79$ & 44 & 5,615 \\
\hline 1980-84 & 1,442 & 7,057 \\
\hline $1985-89$ & 170 & 7,227 \\
\hline 1990-94 & 3 & 7,230 \\
\hline 1995-2000 & 0 & 7,230 \\
\hline
\end{tabular}

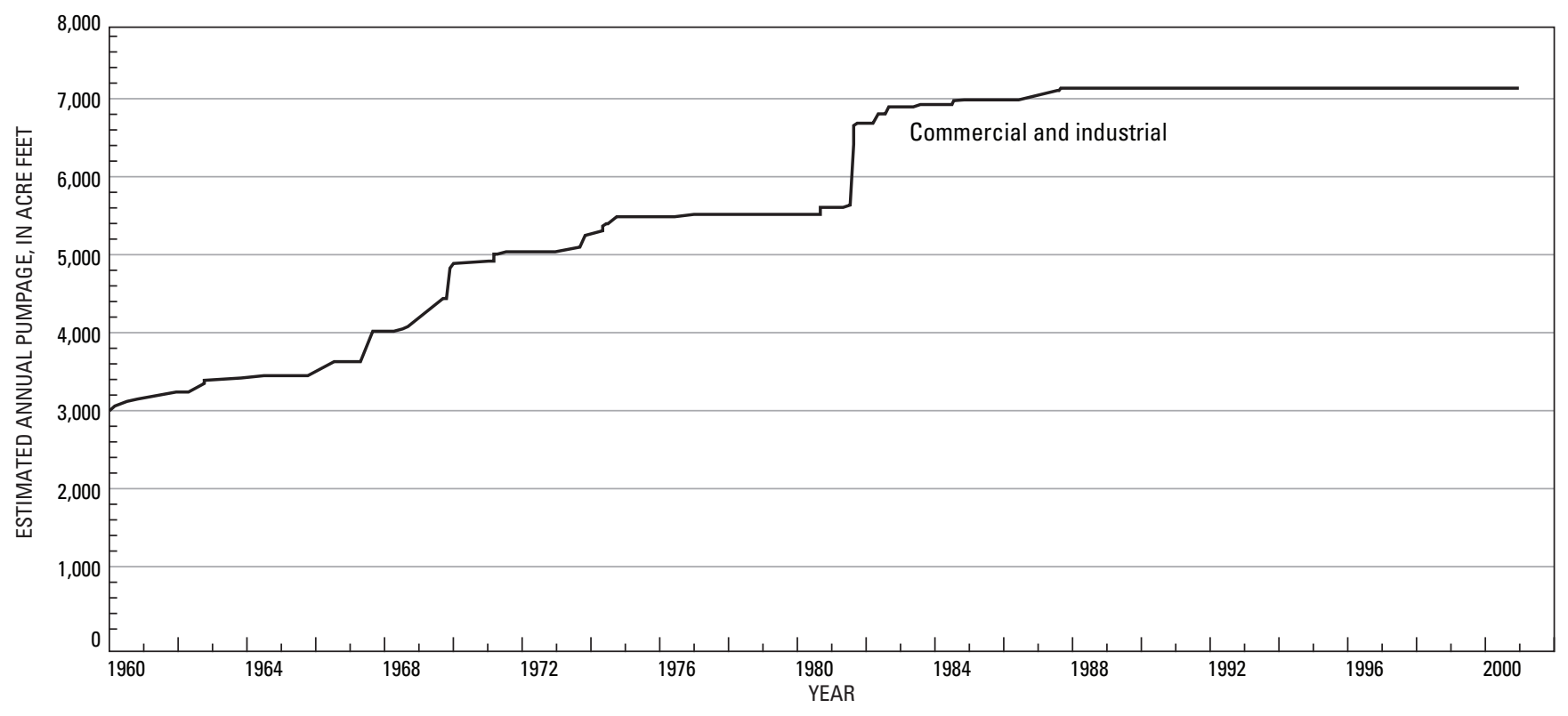

Figure 21. Estimated annual pumpage for commercial and industrial uses, Yakima River Basin, Washington, 1960-2000. 
category. An effective monthly percentage of annual pumpage was then derived by weighting each monthly percentage by the percentage of total. Multiplying these percentages by the total estimated annual pumpage for 2000 yielded an estimated monthly distribution of pumpage (fig. 22). This distribution shows that the least pumpage was in April and July and the largest pumpage was in September (fig. 22).

\section{Fish and Wildlife Propagation}

The pumpage estimates for fish and wildlife propagation are for 9 rights represented by 15 POWs and 2 POWs for 2 other non-WRTS hatchery wells. Table 8 shows estimated pumpage in 2000 was about 9,369 acre-ft $(8.4 \mathrm{Mgal} / \mathrm{d}$ or 3.1 Bgal) for fish and wildlife propagation. Hatchery operations in 2000 accounted for all but 65.5 acre-ft of the total and 3 hatcheries account for 71 percent (about 6,643 acre-ft) of the total. Pumpage estimates for single rights or wells ranged from 2 to 4,192 acre-ft. Total pumpage was about 64 acre-ft by 1979 (only 5 acre-ft of pumpage prior to 1974) and increased by 2,661 acre-ft during 1980-84 (table 8 ). Substantial new pumpage was added during 1990-94 (4,194 acre-ft) and 1995-2000, (2,450 acre-ft).

Figure 23 shows the estimated average monthly distribution of annual pumpage in 2000 ranging from 653 acre-ft in February to 1,030 acre-ft in August. The curve was based on the monthly percentage of annual values calculated using monthly data provided by one of the hatcheries;

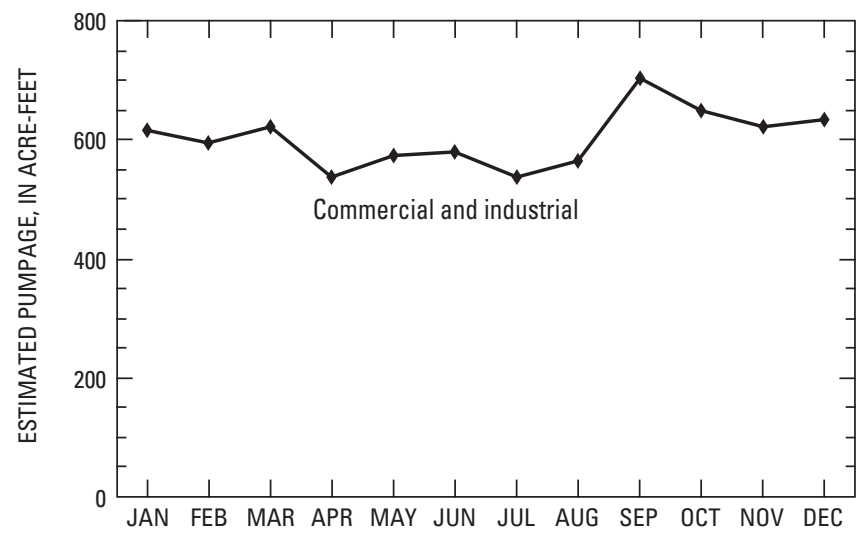

Figure 22. Estimated monthly distribution of annual pumpage for commercial and industrial uses, Yakima River Basin, Washington, 2000. pumpage for this hatchery accounts for about 23 percent of total pumpage. The shape of the monthly curve is influenced by hatchery needs for different life-history stages of salmonids in the Yakima River Basin and availability of surface-water supplies.

Table 8. Estimated annual pumpage for fish and wildlife propagation in 5-year increments, Yakima River Basin, Washington, 1960-2000.

[Years: 1920 is the first year for fish and wildlife propagation pumpage associated with water rights. Pumpage: Pumpage listed is for new quantities added in 5-year increments and cumulative totals. Estimates for total pumpage added during the years prior to 1960 are also shown. All values in acre-feet]

\begin{tabular}{lcc}
\hline \multicolumn{2}{c}{ Years } & \multicolumn{2}{c}{ Pumpage } \\
\cline { 2 - 3 } & $\begin{array}{c}\text { Estimated pumpage } \\
\text { added }\end{array}$ & Cumulative \\
\hline $1920-59$ & 3 & 3 \\
$1960-64$ & 0 & 3 \\
$1965-69$ & 0 & 3 \\
$1970-74$ & 2 & 5 \\
$1975-79$ & 59 & 64 \\
$1980-84$ & 2,661 & 2,275 \\
$1985-89$ & 0 & 2,275 \\
$1990-94$ & 4,194 & 6,919 \\
$1995-2000$ & 2,450 & 9,369 \\
\hline
\end{tabular}

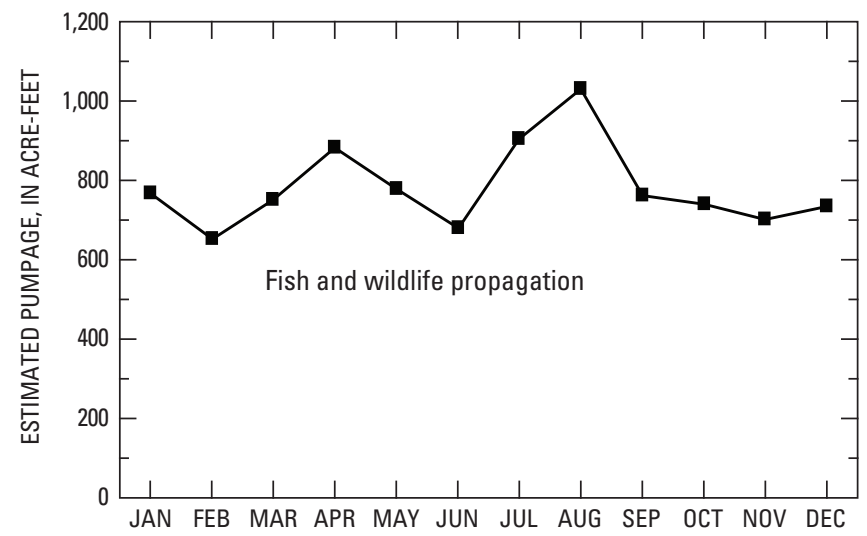

Figure 23. Estimated monthly distribution of annual pumpage for fish and wildlife propagation, Yakima River Basin, Washington, 2000. 


\section{Ground-Water Claims}

The estimates of the pumpage for ground-water claims are for 924 claims. As described in the methods section, it was assumed that the pumpage for other claims is included in other categories of pumpage. Annual pumpage values apply to all years for 1960 through 2000 because a claim is for groundwater use prior to July 1945.

Total estimated annual pumpage for the 924 claims is about 34,310 acre-ft (30.6 Mgal/d or 11.2 Bgal). Total annual pumpage for individual claims ranged from 2.5 to 638 acre- $\mathrm{ft}$ and averaged 37 acre-ft. Irrigation accounts for 32,431 acre-ft (28.9 Mgal/d or $10.6 \mathrm{Bgal})$ or about 95 percent of the total. Irrigation use for the claims ranged from 2.5 to 571 acre-ft and averaged 35 acre-ft. Commercial and industrial uses account for 1,695 acre-ft (1.5 Mgal/d or $0.55 \mathrm{Bgal})$ and averaged about 212 acre-ft. The water supply part of the claims (524 claims had a second PRU of DG) totaled only 185 acre-ft, or less than $0.2 \mathrm{Mgal} / \mathrm{d}$.

The spatial distribution of the annual pumpage for the claims (fig. 24) shows that most claims are located in the lower part of the river basin because that was where most of the early development of ground water occurred. For example, more than 80 percent of total estimated annual pumpage for ground-water claims was in Yakima County, with about 10 percent estimated pumpage in each Benton and Kittitas Counties (about 3,300 acre-ft).

\section{Summary of Pumpage Estimates for all Categories}

Pumpage estimates for each category are summarized and compared in this section. Unless otherwise stated, values exclude pumpage associated with standby/reserve rights. Total pumpage in the Yakima River Basin was about 115,776 acre-ft in 1960 and increased to 312,284 acre-ft by 2000 (fig. 25 ; table 9). The three largest increases in new pumpage were during 1975-79, 1980-84, and 1970-74, respectively. These increases were largely due to increased irrigation pumpage, and similar to most pumpage categories, were directly proportional to the amount of appropriated water in the rights issued during a 5-year period.

Irrigation pumpage accounted for about 60 percent or 188,230 acre-ft of the pumpage in 2000 (table 9) and if irrigation pumpage associated with claims is included, irrigation use in 2000 totaled 220,662 acre-ft (about 69 percent of the total). Excluding claims, irrigation pumpage ranged from 35 to 61 percent of total pumpage during 1960-2000. The next largest pumpage category was municipal use, which in 2000 accounted for about 12 percent (37,273 acre-ft) of the total. The third largest category was for the ground-water claims, with an annual quantity of 34,310 acre-ft $(32,431$ acre$\mathrm{ft}$ was for irrigation). The claims were similar to municipal pumpage in 2000 and account for about 11 percent of the total pumpage. Domestic pumpage (principally from exempt wells) was about 6 percent of the total in $2000(20,036$ acre$\mathrm{ft})$. Pumpage estimates for the Group A systems, livestock, commercial and industrial, and fish and wildlife propagation categories were all relatively similar in 2000 and ranged from about 6,700 to 9,400 acre-ft. Together, these four categories totaled about 30,800 acre-ft of pumpage in 2000 and account for about 10 percent of the pumpage. The least amount of pumpage was for the PWS Group B systems category. In 2000 , this category totaled only 1,647 acre-ft or less than 1 percent of the total estimated pumpage.

Estimated potential pumpage for standby/reserve rights was about 82,812 acre-ft in 2000 , and was the second largest quantity of estimated pumpage (table 9). However, withdrawals for standby/reserve pumpage were only in years with surface-water prorating and are not shown on figure 25 . During extreme prorating years, standby/reserve rights could account for as much as 21 percent of total pumpage. For example, if 2000 was an extreme prorating year, total pumpage in the basin could have been as much as 395,096 acre-ft with standby/reserve pumpage accounting for 21 percent of the total. In years when prorating is not large, for example, when junior surface-water users receive 80 percent of their appropriated water, standby/reserve pumpage would be much less than the estimated value, on the order of 16,600 acre-ft.

The spatial distribution of pumpage reflects the distribution of irrigated crop lands (fig. 2) and population in the basin (fig. 11). Excluding PWS pumpage, in 2000 about 75 percent of pumpage was in Yakima County. Benton County accounts for the next largest amount of pumpage (about 23 percent). Of the three counties in the study area, Kittitas County has the smallest number of acres of ground-water irrigated crops and the smallest population and thus, accounts for only about 3 percent of the pumpage. However, for the PWS category, about 60 percent of the pumpage occurs in Yakima County, a reduction of 15 percent compared to the total for the other 7 categories of pumpage; the reduction is due to the fact that the largest city in the study area (the City of Yakima with a population of about 72,000 in 2000) uses surface water as their primary source of water. About 25 percent of the PWS pumpage occurs in Benton County, followed by about 15 percent in Kittitas County.

The total pumpage in 2000 was about 11 percent of the appropriated quantity of surface water diverted for irrigation and PWS. Total pumpage in 2000 was about $430 \mathrm{ft}^{3} / \mathrm{s}(0.31$ million acre-ft) compared to mean annual precipitation of about $12,000 \mathrm{ft}^{3} / \mathrm{s}$ ( 8.7 million acre-ft), mean annual unregulated streamflow of about $5,600 \mathrm{ft}^{3} / \mathrm{s}$ (4.1 million acre$\mathrm{ft})$, mean annual regulated streamflow of about $3,600 \mathrm{ft}^{3} / \mathrm{s}(2.6$ million acre-ft), and the above diversions of about $3,900 \mathrm{ft}^{3} / \mathrm{s}$ ( 2.8 million acre-ft). Maximum pumpage, about $100 \mathrm{ft}^{3} / \mathrm{s}$, is during the months of July and August. Calculating an average, basin-wide water duty based on the estimates for irrigation pumpage and using the total irrigated acreage of 64,308 acres for the outstanding ground-water applications for irrigation, yields about $185 \mathrm{ft}^{3} / \mathrm{s}$ potential pumpage for the applications if all were approved. 


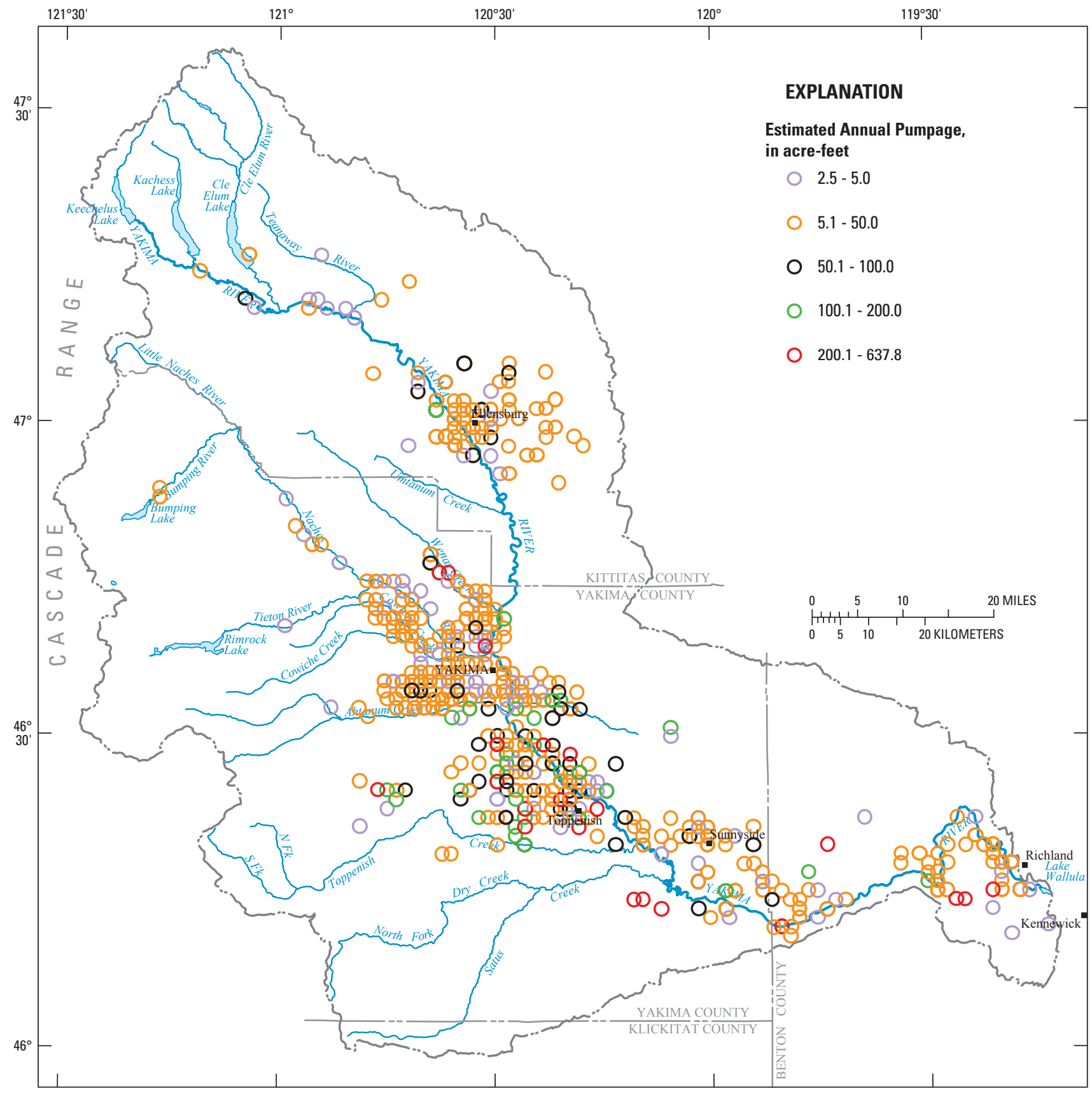

Figure 24. Distribution of estimated annual pumpage for ground-water claims, Yakima River Basin, Washington, 2000. 


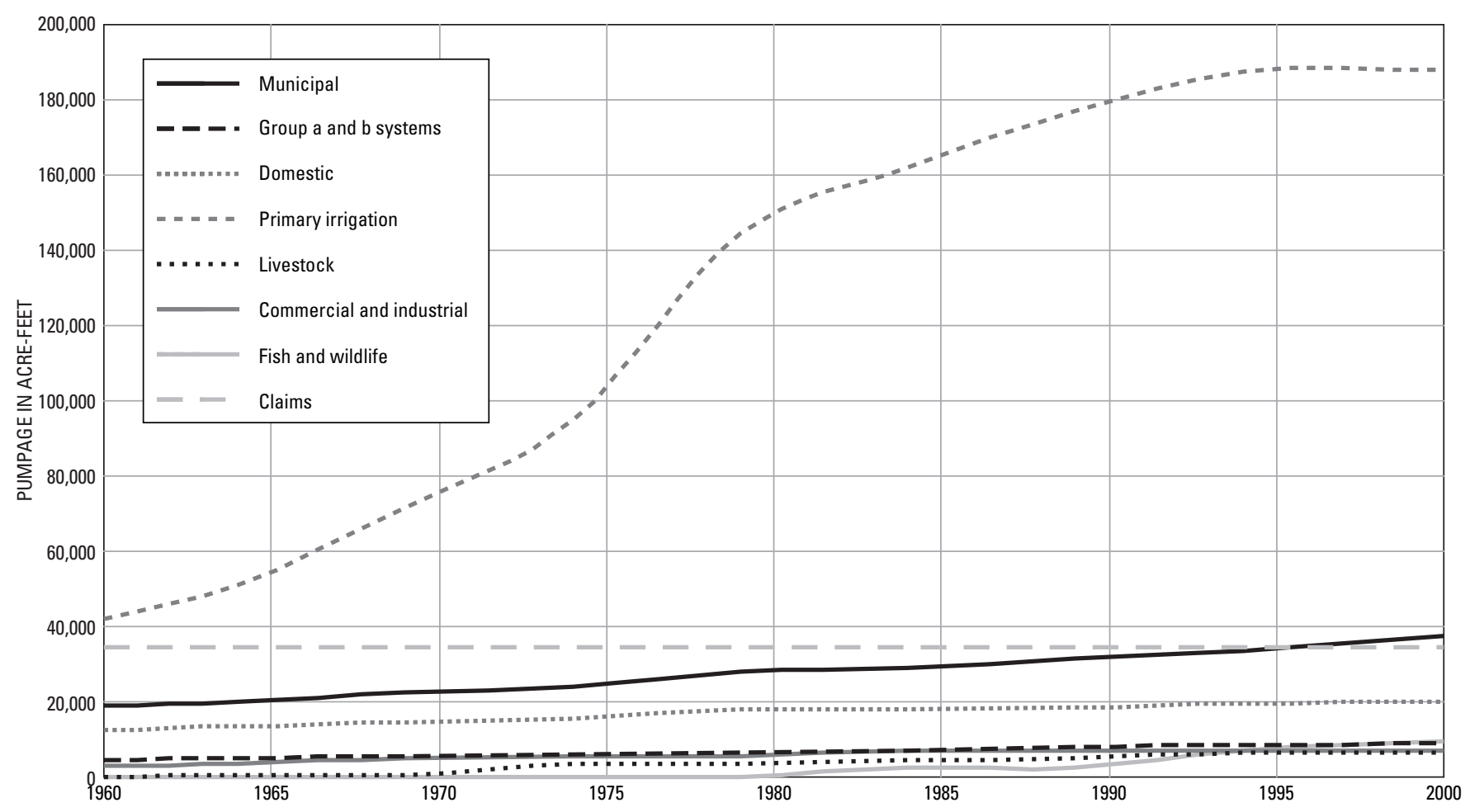

Figure 25. Estimated annual pumpage, by pumpage category, Yakima River Basin, Washington, 1960-2000.

Table 9. Summary of estimated annual pumpage, by pumpage category in 5-year increments, Yakima River Basin, Washington, 1960-2000.

[Public Water Supply: Pre-1960 includes some pumpage for 1960 because initial estimates were calculated for 1960 for Group A and B systems, and domestic. Standby/reserve: Estimates based on pumpage occurred in all years and is not the actual pumpage; pumpage occurred only in 1977, 1979, 1987, 1988, 1992, 1993, and 1994. Claims: About 95 percent of pumpage for claims is for irrigation. Cumulative: cumulative is total pumpage at end of time period and does not include standby/reserve estimates. Total pumpage for each category and for all categories combined is for 2000. Estimates for total annual pumpage existing prior to 1960 are also shown. All values in acre-feet]

\begin{tabular}{|c|c|c|c|c|c|c|c|c|c|c|c|c|c|}
\hline \multirow[b]{2}{*}{ Years } & \multicolumn{3}{|c|}{ Public Water Supply } & \multirow[b]{2}{*}{ Domestic } & \multicolumn{3}{|c|}{ Irrigation } & \multirow{2}{*}{ Livestock } & \multirow{2}{*}{$\begin{array}{l}\text { Commercial } \\
\text { and } \\
\text { industrial }\end{array}$} & \multirow{2}{*}{$\begin{array}{l}\text { Fish and } \\
\text { wildlife }\end{array}$} & \multirow{2}{*}{$\begin{array}{l}\text { Ground- } \\
\text { water } \\
\text { claims }\end{array}$} & \multirow{2}{*}{$\begin{array}{c}\text { Total } \\
\text { for all } \\
\text { categories }\end{array}$} & \multirow{2}{*}{$\begin{array}{l}\text { Cumu- } \\
\text { lative } \\
\text { without } \\
\text { standby } \\
\text { reserve }\end{array}$} \\
\hline & Municipal & $\begin{array}{l}\text { Group A } \\
\text { systems }\end{array}$ & $\begin{array}{l}\text { Group B } \\
\text { systems }\end{array}$ & & Total & Primary & $\begin{array}{l}\text { Standby/ } \\
\text { reserve }\end{array}$ & & & & & & \\
\hline Pre-1960 & 19,127 & 3,888 & 858 & 12,379 & 42,000 & 41,896 & 104 & 222 & 3,093 & 3 & 34,310 & 115,880 & 115,776 \\
\hline $1960-64$ & 628 & 331 & 73 & 1,187 & 9,299 & 9,299 & 0 & 208 & 438 & 0 & 0 & 12,164 & 127,940 \\
\hline 1975-79 & 4,236 & 422 & 93 & 2,914 & 99,474 & 49,399 & 50,075 & 84 & 44 & 58 & 0 & 107,325 & 241,147 \\
\hline $1980-84$ & 975 & 458 & 101 & -107 & 28,845 & 17,507 & 11,338 & 996 & 1,442 & 2,661 & 0 & 35,371 & 265,180 \\
\hline $1985-89$ & 2,614 & 586 & 110 & 305 & 20,687 & 14,927 & 5,760 & 461 & 170 & 0 & 0 & 24,933 & 284,352 \\
\hline 1990-94 & 1,793 & 449 & 119 & 1,175 & 21,821 & 10,398 & 11,423 & 1,527 & 3 & 4,194 & 0 & 31,081 & 304,010 \\
\hline
\end{tabular}




\section{Reliability of Pumpage Estimates}

Reliability of ground-water pumpage estimates establishes potential bounds on estimated pumpage. However, the most reliable estimates are those reported in the previous sections. Many factors affecting pumpage estimates make it difficult to assign a measure such as a percent error or a root mean square error. Therefore, a potential range in values is estimated for the pumpage categories. The range delineates an estimated minimum or maximum pumpage value for a category. In addition, the values probably have an increasing error as the estimates are extrapolated further back in time. Therefore, only the reliability of the 2000 estimates is discussed and it is assumed that estimates extrapolated back in time have an increasing bound, as a percent error, that is a function of the estimated quantity of pumpage for any particular category and year. Although standby/reserve pumpage would have been zero in 2000, the reliability of standby/reserve pumpage estimates is assessed in this section. The reliability is described for the categories in the same order they were presented in the previous sections. Frost protection category reliability is not discussed because pumpage was assumed to be negligible and was set equal to zero. Last, excluding the provided data, the methods used to estimate pumpage are invariant over time. For most water users, the amount of pumpage in any year varies, and these decreases or increases in pumpage are not captured in the estimates. Therefore, there is some, but an unknown amount, of error in the annual values.

\section{Public Water Supply and Domestic}

Three classes of PWS estimates were: (1) municipal and large Group A systems with data available, (2) 62 Group A and B systems that provided some data, and (3) remaining systems with no data. In 2000, the first class served about 203,000 people, the second class served about 10,100 people, and the third class about 27,000 people. This total population of about 240,000 accounted for about 71 percent of the population in the basin in 2000 . In addition, pumpage for the PWS category, which totals about 46,385 acre-ft, is the second largest pumpage category.

The pumpage estimate for the first two classes (about 41,496 acre-ft, table 10) can be considered the most reliable of the estimates because it is based on provided data. Errors inherent in metering, compilation of data to digital form from paper copies, and other factors are minor compared to both the total pumpage for this category and to total pumpage. The reliability of estimates for these two classes was assumed to be good with a potential error of about 5 percent or about 2,075 acre-ft, with most of that quantity (1,864 acre-ft) accounted for by the municipal systems. The lower and upper bounds for these two classes are 35,409 and 4,012 acre-ft and 39,137 and 4,434 acre-ft, respectively (table 10).

The third class of PWS pumpage has a larger potential error. This class totaled 4,890 acre-ft in 2000. Based on available databases and contacts with water-system operators, the population served by this class was the best estimate available. Therefore, the reliability of these estimates is a function of the basin-wide average per capita rates (251 and $109 \mathrm{gal} / \mathrm{d}$ ) used to derive the estimates. The $251 \mathrm{gal} / \mathrm{d}$ rate was applied to systems outside irrigation districts that served about 10,000 people, and the $109 \mathrm{gal} / \mathrm{d}$ rate was applied to systems in irrigation districts that served about 17,000 people. When combined, these values yield an effective population weighted rate of $162 \mathrm{gal} / \mathrm{d}$.

Table 10. Reliability of annual pumpage estimates, Yakima River Basin, Washington, 2000.

[All values in acre-feet]

\begin{tabular}{lrrr}
\hline \multicolumn{1}{c}{ Category } & $\begin{array}{c}\text { Estimated } \\
\text { pumpage }\end{array}$ & $\begin{array}{r}\text { Lower } \\
\text { bound }\end{array}$ & $\begin{array}{r}\text { Upper } \\
\text { bound }\end{array}$ \\
\hline $\begin{array}{l}\text { Public Water Supply } \\
\quad \text { Municipal and large }\end{array}$ & 37,273 & 35,409 & 39,137 \\
$\quad \begin{array}{r}\text { Group A systems } \\
\quad \text { with data }\end{array}$ & & & \\
$\quad$ Group A and B systems & 4,222 & 4,012 & 4,434 \\
$\quad$ ith data & & & \\
$\quad$ Systems with no data & 4,890 & 3,562 & 9,056 \\
Domestic (exempt) & 20,036 & 13,135 & 33,393 \\
Irrigation & & & \\
$\quad$ Primary & 188,230 & 150,230 & 226,230 \\
$\quad$ Standby/reserve ${ }^{1}$ & 82,812 & 0 & 82,812 \\
Livestock & 6,726 & 5,881 & 6,726 \\
Commercial and industrial & 7,230 & 1,030 & 10,700 \\
Fish and wildlife & 9,369 & 8,901 & 9,837 \\
Ground water claims & 34,310 & 27,410 & 41,210 \\
All categories & 395,096 & 249,570 & 463,534 \\
Without standby/reserve & 312,284 & 249,570 & 380,723 \\
\hline
\end{tabular}

${ }^{1}$ Standby/reserve pumpage occurs only in years with prorating and for 2000, would be zero. Values represent the potential range of pumpage under different prorating values that have occurred in the past. 
The domestic pumpage value of $251 \mathrm{gal} / \mathrm{d}$ is larger than the statewide average, but it is known that the per capita value in eastern Washington is larger than in western Washington due to a higher water demand resulting from less precipitation and warmer summers (Dion and Lum, 1977; Lane, 2004; Washington State Department of Health, 2001). This per capita rate, which was derived from provided data, also is larger than many municipal rates. However, Dion and Lum (1977) indicated that the per capita rate for the three counties in the study area ranged from about 227 to $344 \mathrm{gal} / \mathrm{d}$, which are higher than Lane's (2004) range of 115 to $230 \mathrm{gal} / \mathrm{d}$. In addition, DOH's average water-system design rate for the three-county area is on the order of 280 to $300 \mathrm{gal} / \mathrm{d}$.

Average per capita rate for all systems that provided data and that do not use surface water as a drinking water source is $118 \mathrm{gal} / \mathrm{d}$. The $118 \mathrm{gal} / \mathrm{d}$ value can be considered a lower bound on an effective basin-wide average, especially because this value includes municipal systems whose pumpage includes water for commercial and industrial uses. Using this rate divided by the effective population weighted rate of 162 gal/d and multiplying it by the pumpage estimate for Group A and B systems without data yields 3,562 acre-ft of pumpage as an estimate of a lower bound (table 10) with a difference of 1,329 acre-ft. Assuming that DOH's rate of $300 \mathrm{gal} / \mathrm{d}$ is the upper bound for a basin-wide average, yields 9,056 acre- $\mathrm{ft}$ as an upper bound (table 10), a potential increase of 4,166 acre-ft. Note that 80 percent of per capita values calculated from the provided data were less than $300 \mathrm{gal} / \mathrm{d}$.

Reliability of domestic (primarily exempt wells) estimates can be calculated as above using an effective rate of $180 \mathrm{gal} / \mathrm{d}$ based on the distribution of exempt population residing in and out of irrigation districts. Ratios of the low and high per capita values to the effective rate multiplied by the estimated pumpage yields a lower bound of 13,135 acre-ft and an upper bound of 33,393 acre-ft (table 10). In addition, about 322 acre- $\mathrm{ft}$ of pumpage was estimated for domestic use included in other categories, primarily the irrigation category. If it is assumed that the census numbers are exact and all domestic use was accounted for, the exempt well pumpage could be 322 acre-ft too large. However, this small value is much less than potential errors due to the estimates of the average daily per capita rate. For example, increasing or decreasing the effective basin-average daily rate by only 5 gal, increases or decreases the total pumpage by about 500 acre-ft.

\section{Irrigation}

Several factors help to define the reliability of irrigation estimates; however, reliability of irrigation pumpage estimates is more difficult to assess because no reliable source is available for comparison. The reliability discussed is for the estimated pumpage for primary irrigation rights, which was 188,230 acre-ft. Reliability of pumpage estimates for standby/ reserve rights, which was 82,812 acre-ft, is addressed after the discussion of the primary rights.

For areas defined by zip codes in the part of the basin where power data was available, we estimated 79,051 acre$\mathrm{ft}$ of pumpage outside of the irrigation districts and within boundaries of irrigated lands as defined by the spatial distribution of land use developed for the study. Based on power consumption data for the zip code areas, pumpage outside the irrigation districts was 27,788 acre-ft for the basalt well equation 1, 61,636 acre- $\mathrm{ft}$ for the overburden well equation 2, and 61,851 to 149,988 acre-ft for the PCC equation. The basalt equation produces an unreasonable value because the average crop-water use would need to be less than 1 acre-ft/acre, which could not support most crop types such as orchards, hops, alfalfa, and row crops. The large pumpage value calculated from the median of the measured PCC values yields about 5.5 acre-ft/acre, which also is unreasonable because this value is 2 to $3 \mathrm{ft}$ more than the needs of most crop types grown in the zip code areas. Therefore, a range of about 62,000 to 100,000 acre- $\mathrm{ft}$ is more reasonable, suggesting that the pumpage estimates may be on the order of 22 percent too large to 21 percent too small. This coarse comparison assumes that the allocation of power consumption data based on using irrigated lands and boundaries of irrigation districts is reasonable, and that power consumption for surface- and ground-water uses are approximately the same.

Comparison of DOA acreage of surveyed fields and allowable acreage for irrigation rights for selected TRSs outside of irrigation districts indicated that allowable acreage generally was greater than actual acreage, thus the acreage of irrigated croplands used to calculate pumpage estimates may be high. However, given the aggregation of the DOA field data to the section level, the varying number of fields in each section, and that the allowable acreage for a right may extend across several sections, it is not possible to determine the actual versus allowable acreage for most rights. The acres used for the calculations generally could be on the order of 5 percent too large, which in turn, could result in estimates on the order of 10,000 acre-ft too large. 
For the cases where pumpage data were provided, the difference between estimated and provided values was only 1 percent for a large orchard, but was 1.25 to 2.14 times larger for two large vineyards. The information provided indicates the highly efficient use of water (1.0 to 1.7 acre-ft) in the vineyards. The total irrigation pumpage estimate may be as much as about 15,000 acre- $\mathrm{ft}$ too high if all vineyards are as efficient (use of drip irrigation).

Cline and Knadle (1990) and Van Metre and Seevers (1991) indicate that the estimated pumpage for an individual well may vary from the actual value but that the total estimate for many wells is reasonable; Van Metre and Seevers (1991) identify the total error as 4 percent. However, this error generally is related to some particular year. Based on local climatic conditions, soil moisture, and soil properties, pumpage for any particular field with the same crop varies on a year to year basis. For example, one farm provided irrigation pumpage data for several years that averaged 860 acre-ft, but the annual values ranged from about 600 to 1,100 acre-ft. For the crop types in the basin, the long-term average cropwater use value used for estimating pumpage had interannual variations over the 50-year calculation period of as much as 3-4 in. due to the combination of temporally varying climate conditions and soil properties. It is assumed that by using an effective long-term crop-water use value the pumpage estimate should represent a reasonable average, especially considering the continually changing crop patterns.

Kinnison and Sceva (1963) estimated about 24,000 acre-ft of irrigation pumpage (about 50 percent of the annual appropriated quantity) for 1953 compared to this study's estimate of about 36,000 acre-ft (about 77 percent of the annual appropriated quantity). Laird and Walters (1967) estimated about 79,000 acre-ft of irrigation pumpage (about 97 percent of the annual appropriated quantity) for 1965 , compared to this study's estimate of about 56,000 acre-ft (about 73 percent of the appropriated quantity). Last, Parker (1971) estimated irrigation pumpage at about 81,000 acre-ft for 1970 compared to this study's estimate of about 75,000 acre-ft; both estimates have a similar percentage of the appropriated quantity (73 and 78 percent, respectively). Note that the annual appropriated quantity increased by about 25,000 acre-ft from 1965 to 1970, and either the previous 1965 estimate is too high or the 1970 estimate is too low. In addition, previous estimates for 1965 and 1970 were for the three-county area, which is larger than the study area and contains additional irrigated croplands in the part of Benton County outside the basin.
The TCWRA (Tri-County Water Resource Agency, 2003) used the appropriated right for both primary and standby/ reserve rights as the estimate of irrigation pumpage. Using such a value would increase the 2000 estimate of 271,042 acre-ft by about 100,000 acre-ft. Based on values measured during this study, pumpage averaged 89 percent (median of 71 percent) of the appropriated value and excluding the largest percent, the average percentage of appropriated water pumped was 73 percent (median of 67 percent). These percentages suggest that the 2000 pumpage estimate would not be 100,000 acre-ft too small.

As can be seen from above, the irrigation estimate for primary rights can possibly be either too low or too high. Thus, the potential range is estimated to be on the order of 20 percent of the annual value (about 38,000 acre-ft). The latter value yields 150,230 and 226,230 acre-ft as the lower and upper bounds (table 10).

The possible variations in standby/reserve pumpage were described previously in the 'Irrigation' section of the pumpage estimates; the section concluded that the pumpage would be zero in years without prorating. Therefore, the lower bound would be 0 acre-ft for standby/reserve pumpage (table 10), for example, in 1996 or 2000, years without prorating, there would have been no standby/reserve pumpage. The upper bound would be at most equal to the estimated value of 82,812 acre-ft (table 10), especially considering that the 207 standby/ reserve rights with a smaller water duty of 0.1 to 2.0 acre-ft/ acre were estimated to be fully used.

\section{Livestock}

The pumpage estimate for livestock was based on the full appropriated right. Information was available for only one livestock right that also had PRUs of DM and IR, but had no allowable acreage for irrigation. The provided information was only 15 percent of the right but this appeared to be a unique situation. Therefore, this value was not directly used for estimating a potential range in estimates.

The full appropriated right is a reasonable assumption for dairy use, which accounts for 23 percent of the total. However, the remaining livestock pumpage may be less. Including the probable dairy use as part of the dairy use reduces the remaining livestock estimate to about 4,900 acre-ft. About 88 percent of the latter is withdrawn by 4 large operations (more than 80 percent is accounted for by one operation). Interviews with personnel from a large operation indicate that in most years they withdraw the appropriated quantity, with 
highest demand in summer and lowest demand in winter. Therefore, about 4,350 acre-ft of the remaining pumpage estimate appears to be reasonable, leaving about 550 acre-ft of pumpage. Larger appropriated rights average about 180 acre-ft and range from 16.5 to 770 acre-ft, whereas the rights for the remaining 550 acre-ft of pumpage average about 19 acre-ft and range from 1 to 86 acre-ft with 70 percent less than 20 acre-ft. Most estimates associated with the 550 acre-ft are thus for small operations that may or may not use their full right. For estimating purposes, this value was assumed to be as small as 225 acre-ft. Given that the number of livestock fluctuates and their needs change due to various factors, the remaining 6,174 acre-ft of estimated livestock pumpage was assumed to potentially be 10 percent smaller. Therefore, pumpage estimates may be as much as 845 acre-ft $(225+620)$ too large, yielding a lower bound of 5,881 acre-ft (table 10).

\section{Commercial and Industrial}

Percentages of appropriated rights used for estimating the pumpage associated with the PRUs of CI and HE were much smaller than would be expected, but were based on provided data. These percentages were 4 and 14 percent for rights with a single PRU of $\mathrm{HE}$ and the remaining rights had a percentage of 25. Excluding the largest percentage, the second largest percentage for the provided data was 39 percent. Previous industrial pumpage estimates ranged from slightly more than the appropriated quantity to 47 percent of the appropriations. The most current previous percentage for the study area was about 48 percent of appropriated water was being pumped (Dion and Lum, 1977), which is similar to the 47 percent estimated by Parker (1971). Assuming that the potential upper range in estimates is on the order of 48 percent, the estimate may be as much as 3,470 acre-ft too small. The upper bound then would be about 10,700 acre-ft (table 10). For a lower bound, the authors determined that less than 4 percent of the allocated water would be too small and chose to use a 4 percent value as the smallest value that should be applied to all rights. This percentage gives a lower bound of about 1,030 acre-ft (table 10). In comparison, the commercial and industrial estimates for irrigation rights were estimated to average about 25 percent of the allocated water, with most values between 15-29 percent. Provided data for commercial and industrial uses also indicated values on the order of 25 percent. The above suggests that the estimate of the lower bound using 4 percent of the appropriated water should be considered too low, but establishes the smallest possible value.

\section{Fish and Wildlife Propagation}

The estimated pumpage for fish and wildlife propagation $(9,369$ acre-ft) was primarily based on provided data that account for about 99 percent of the pumpage. Similar to the first two classes of PWS, the reliability was assumed to be good with a potential error of about 5 percent. The 5 percent value results in lower and upper bounds of 8,901 and 9,837 acre-ft, respectively (table 10).

\section{Ground-Water Claims}

Ground-water claims were the most problematic category of pumpage to derive estimates. Estimated pumpage for claims was 34,310 acre-ft and the claims in WRTS total about 270,000 acre-ft. The latter value could not be possible because the total ground-water rights in the basin prior to July 1945 totaled only about 39,000 acre-ft, and maximizing the estimates of drinking water supplies using a $300 \mathrm{gal} / \mathrm{d}$ per capita rate and the non-municipal ground-water supplied population from 1950 gives only 33,000 acre-ft. Together, the total appropriated quantity and drinking water supply would only account for 27 percent of the claimed annual pumpage. This indicates that at least an additional 49,000 acres would have to have been irrigated with ground water by claims or nearly 4 times the allowable amount of acres for the rights, which is unreasonable. Indeed, the claims included in the estimate already account for about 12,790 acres of croplands, which is more than the 9,682 allowed under the irrigation rights as of July 1945.

In addition, pumpage for claims for this report was an estimate of pumpage that was likely not accounted for in the other categories. The PWS and domestic pumpage are reasonably accounted for, except for potentially about 900 1,200 acre-ft of applied water for the 451 claims for selfsupplied domestic use with 1 acre of allowable irrigation claimed. Commercial and industrial pumpage should account for most of the actual use with possibly only a few unaccounted for claims.

Based on the above, the pumpage estimate for groundwater claims probably accounts for most, if not more, of pumpage not included in the other categories. The reliability of the estimate is assumed to be about 20 percent $(6,900$ acre$\mathrm{ft}$ ) with the lower and upper bounds being 27,410 and 41,210 acre-ft, respectively (table 10). 


\section{Comparison of Appropriated Ground-Water Rights and Estimated Pumpage}

Comparing the quantity of appropriated water and the estimated pumpage delineates existing and potential pumpage in the basin. Future planning for water supply is dependent on both quantities. The comparisons, which are for the values for 2000, also provide valuable and needed information for ground-water flow models being constructed as part of this study. Of the eight pumpage categories, estimates for six categories can be compared to the appropriated quantities. These categories are: PWS, irrigation, frost protection, livestock, commercial and industrial, and fish and wildlife propagation. Within the PWS category, two classes can be compared - the municipal pumpage and the remaining Group $\mathrm{A}$ and $\mathrm{B}$ systems. Part of the domestic class of pumpage also can be compared, but only for the 63 domestic wells with rights with a principal purpose of supplying drinking water. Pumpage for all other domestic wells with additional PRUs are included in other categories. Allowable quantities associated with these latter rights vary widely, from 1 to 2,600 acre-ft, and the estimated domestic pumpage part of the rights with additional PRUs is about 322 acre-ft; this pumpage is primarily included in the irrigation or livestock use categories. Although exempt wells do not have an appropriated quantity, a well has a legal right to pump up to 5,000 gal/d (about 5.6 acre-ft/y) and thus it also is important to account for this allowable quantity.

As of 2000, the estimated and appropriated pumpage for municipal uses was about 37,273 and 107,958 acre-ft, respectively (table 11). The non-municipal Group A and B systems have an estimated pumpage of 9,112 acre-ft compared to an appropriated value of 21,945 acre-ft. Domestic pumpage was estimated to be about 31 acre-ft for the 63 rights with a single PRU of DS and the total appropriated value was 166 acre-ft.

Irrigation accounts for the largest part of the pumpage in the Yakima River Basin and the total appropriated water for this category is 371,189 acre-ft. Estimated pumpage (271,042 acre- $\mathrm{ft}$ ) is about 73 percent of the appropriated value and is 100,147 acre-ft less than the appropriated value. In 2000, the amount of unused appropriated irrigation water was similar to the total estimated pumpage for all other categories combined.

Pumpage associated with primary irrigation rights was about 70 percent of the appropriated quantity (266,502 acre-ft, table 11). Standby/reserve rights are associated with 104,687 acre-ft of appropriated water. Note that for any individual right, a change in a crop type can change the percentage of the appropriated value used in a year.
Frost protection pumpage was estimated to be zero and the 21 rights with a single PRU of FP (most in irrigation district boundaries and estimated to be standby/reserve) have an appropriated value of 299 acre- $\mathrm{ft}$ (table 11).

The livestock category includes 6,726 acre-ft of appropriated water and the estimates were set to the appropriated quantity (table 11), so there is no difference between the two values. Livestock uses associated with irrigation-rights category average about 25 percent of the appropriated value and were estimated to account for about 5,166 acre-ft of the irrigation total. Compared to the livestock category, there is a large difference between the estimated and appropriated quantities of pumpage for the commercial and industrial category. Estimated pumpage, 7,230 acre-ft, was only 23 percent of the appropriated quantity (table 11) resulting in a difference of 24,389 acre-ft. The difference between estimated and appropriated values also is large for the fish and wildlife propagation category, but the estimated pumpage in table 11 does not include about 4,500 acre-ft of pumpage for wells without appropriated quantities.

Table 11. Appropriated ground-water quantity and estimated pumpage for six categories of pumpage, Yakima River Basin, Washington, 2000.

[Appropriated quantity: includes about 21,000 acre-feet of appropriated water not listed in Water Rights Tracking System (WRTS), about 6,700 acrefeet of which is outside the basin. All values in acre-feet]

\begin{tabular}{lrrr}
\hline \multicolumn{1}{c}{ Category } & $\begin{array}{c}\text { Estimated } \\
\text { pumpage }\end{array}$ & $\begin{array}{c}\text { Appropriated } \\
\text { quantity }\end{array}$ & Difference \\
\hline $\begin{array}{l}\text { Public Water Supply } \\
\quad \text { Municipal systems }\end{array}$ & 37,273 & 107,958 & 70,685 \\
$\quad \begin{array}{l}\text { Group A and B } \\
\quad \text { systems }\end{array}$ & 9,112 & 21,945 & 12,833 \\
$\begin{array}{l}\text { Domestic } \\
\text { Irrigation }\end{array}$ & & & \\
$\quad$ Primary & 31 & 166 & 135 \\
$\quad$ Standby/reserve & & & \\
$\begin{array}{l}\text { Frost protection } \\
\text { Livestock }\end{array}$ & 188,230 & 266,502 & 78,272 \\
Commercial and & 82,812 & 104,687 & 21,875 \\
$\quad$ industrial & 0 & 299 & -299 \\
Fish and wildlife $^{5}$ & 6,726 & 6,726 & 0 \\
\hline
\end{tabular}

${ }^{1}$ Includes all estimated pumpage, including one small municipality without a right.

${ }^{2}$ Includes most systems, including those without rights and some outside the basin; appropriated water includes some systems not identified as a Group A or B system.

${ }^{3}$ Standby/reserve pumpage occurs in years with prorating, and for 2000 would be zero.

${ }^{4}$ Includes estimated pumpage for small dairies under an exempt status and associated 5,000 gallons per day allowable quantity per dairy in the appropriated value.

${ }^{5}$ Includes only estimated pumpage for wells with rights, about 13,000 acrefeet of appropriated water not included in WRTS. 
Estimated pumpage in 2000 from all wells with rights was about 60 percent of the appropriated quantity, representing an absolute difference of 220,164 acre-ft. This quantity is reduced to 198,289 acre- $\mathrm{ft}$ (about $275 \mathrm{ft}^{3} / \mathrm{s}$ ) when standby/ reserve pumpage is not included (about 60 percent of the appropriated quantity). Thus, as of 2000, the total unused part of the appropriated annual quantity is larger than the estimated pumpage for most categories and is about 56 percent of the total estimated pumpage in 2000. To understand potential effects of new pumpage on the ground-water flow systems, it will be important to estimate the potential effects on groundwater availability if all appropriated water were withdrawn.

Based on the estimated number of exempt wells in the basin as of 2000 and using the maximum allowable withdrawal rate of 5.6 acre-ft, an estimate was made of the allowable withdrawals from exempt wells. This quantity was about 241,000 acre-ft or about $215 \mathrm{Mgal} / \mathrm{d}$ in 2000. This quantity is larger than the estimated primary irrigation pumpage in 2000. The potential effects of all exempt wells withdrawing the full allowable amount also need to be understood.

\section{Summary and Conclusions}

To provide a necessary framework to assess ground water availability in the Yakima River Basin, ground-water pumpage was estimated for eight categories of water use for 1960-2000. Information was presented and described concerning (1) water wells in the basin; (2) ground-water rights and water uses; (3) relations between rights and a drillers' logs; (4) relation between primary and standby/reserve rights; (5) methods used to estimate ground-water pumpage for 1960-2000 (annual and (or) 5-year values) for eight categories pumpage; (6) estimates of pumpage for each category and a summary of these estimates; (7) delineation of the reliability of estimates for each category of pumpage; and (8) comparison of estimated and appropriated quantities for six categories of pumpage.

Ground-water is the principal source of drinking water in the basin and supplies about 330,000 people in the threecounty area or about 80 percent of the population. At least 45,000 wells in the basin withdraw water for various uses. Drinking-water use accounts for most wells. However, irrigation of croplands is the largest use of ground water, although less than 2,300 irrigation wells are in the basin. Agriculture and its related industries and infrastructure is the dominant economic driver in the basin.

To provide a better understanding of ground-water availability, the ground-water rights were associated, to the extent possible, to drillers' logs. This association allowed for an assessment of the spatial withdrawals, by depth of ground water. Of the 2,874 active rights identified in the Water Rights Tracking System, all but 220 were associated with a log. It is acknowledged that all associations may not be correct. Associations include temporal changes in the points of withdrawal to account for such aspects as well deepening, reconditioning, abandoning and replacing with a new well or wells, and constructing additional wells. As part of this analysis of rights, an estimate was made of which irrigation wells held primary rights and which wells held rights that are, in almost all cases, supplemental to junior surface-water rights. About 560 ground-water rights with allowable acreage for irrigation were estimated to be standby/reserve and 21 rights with the sole purpose of frost protection were also estimated to be standby/reserve.

Pumpage estimates varied widely, both temporally and spatially, and within and between the pumpage categories. If the estimate of standby/reserve pumpage is included, about 395,096 acre-ft of pumpage occurred in 2000. Without standby/reserve pumpage, the total annual value in 2000 was 312,284 acre-ft, which was an increase of about 200,000 acre-ft since 1960. In 2000, the largest amount of withdrawals is for irrigation use at about 271,042 acre-ft. The standby/ reserve part of the total irrigation pumpage was estimated to potentially be 82,812 acre-ft in a year with extreme prorating; the standby/reserve pumpage would occur only in years of prorating of junior surface-water rights. Pumpage in a prorating year would be some percentage of the estimated value and the percentage is a function of the amount of prorating for the year. For 2000, a year without prorating, the total irrigation pumpage was about 188,230 acre-ft. The standby/reserve estimates are important for understanding the effects on ground-water availability from potential additional pumpage in prorating years.

The next largest category of pumpage was for PWS at 46,385 acre-ft, followed by ground-water claims at 34,310 acre-ft. Pumpage for claims (mostly for irrigation) were the most difficult to estimate, but the estimate is considered reasonable. Exempt well pumpage was 20,036 acre-ft, which, excluding the standby/reserve pumpage is about 5 percent of the total pumpage. Together, the remaining categories of livestock, commercial and industrial, and fish and wildlife propagation account for about 23,323 acre-ft or about 6 percent of the pumpage.

The reliability of the pumpage estimates for 2000 was estimated for each category by estimating a lower and upper bound. Based on these ranges, the total 2000 pumpage estimate can be as small as 249,570 acre-ft or as large as 463,534 acre-ft. Excluding the standby/reserve pumpage, this potential range is reduced to from 249,570 to 380,723 acre-ft. Estimates with the largest potential ranges were for primary and standby/reserve irrigation values. The PWS, and fish and wildlife propagation categories had the smallest percentage error ( 5 percent) because estimates were principally based on provided data.

Excluding standby/reserve pumpage, the total annual pumpage for 2000 was estimated to be about 11 percent of the appropriated quantity of the surface water diverted for irrigation and PWS and about 56 percent of appropriated ground water. Total pumpage in 2000 without standby/reserve pumpage was about $430 \mathrm{ft}^{3} / \mathrm{s}$ (0.31 million acre- $\mathrm{ft}$ ) compared to mean annual precipitation of about $12,000 \mathrm{ft}^{3} / \mathrm{s}(8.7$ million 
acre-ft), unregulated streamflow of about $5,600 \mathrm{ft}^{3} / \mathrm{s}(4.1$ million acre-ft), regulated streamflow of about $3,600 \mathrm{ft}^{3} / \mathrm{s}$ (2.6 million acre-ft), and the above diversions of about 3,900 $\mathrm{ft}^{3} / \mathrm{s}$ (2.8 million acre- $\mathrm{ft}$ ). The maximum pumpage occurs during July and August and is on the order of $100 \mathrm{ft}^{3} / \mathrm{s}$. Potential pumpage was estimated to be about $185 \mathrm{ft}^{3} / \mathrm{s}$ for the outstanding applications.

\section{Acknowledgments}

The authors wish to thank the many municipal publicwater suppliers, irrigators, and industrial well owners for their cooperation in providing access to their records. Thanks also to the many smaller public-water suppliers who provided pumpage and population served data. Government agencies and groups such as the Bureau of Reclamation, the Washington State Departments of Ecology and Health, and the Yakama Nation provided valuable support and access to their records during this study.

\section{References Cited}

Bureau of Reclamation, 1999, Yakima River Basin Water Enhancement Project, Washington, Final Programmatic Environmental Impact Statement: U.S. Department of Interior, Bureau of Reclamation, Pacific Northwest Region, Upper Columbia Area Office, Yakima, Wash., 197 p.

Carlston, C.W., 1943, Notes on the early history of water-well drilling in the United States: Economic Geology, v. 38, no. 2, p 119-136.

Cline, D.R., and Collins, C.A., 1992, Ground-water pumpage in the Columbia Plateau, Washington and Oregon, 1945-84: in Prince, K.R., and Johnson, A.I., eds., Aquifers of the Far West: American Water Resources Association, Monograph Series No. 16, p. 99-107.

Cline, D.R., and Collins, C.A., 1993, Ground-water pumpage in the Columbia Plateau, Washington and Oregon, 1945 to 1984: U.S. Geological Survey Water-Resources Investigations Report 90-4085, 31 p., 5 pls.

Cline, D.R., and Knadle, M.E., 1990, Ground-water pumpage from the Columbia Plateau regional aquifer system, Washington, 1984: U.S. Geological Survey Water-Resources Investigations Report 87-4135, 32 p., 1 sheet.

Collins, C.A., 1987, Ground-water pumpage from the Columbia Plateau Regional Aquifer System, Oregon, 1984: U.S. Geological Survey Water-Resources Investigations Report 87-4238, 21 p., 1 pl.
Cuffney, T.F., Meador, M.R., Porter, S.D., and Gurtz, M.E., 1997, Distribution of fish, benthic invertebrate, and algal communities in relation to physical and chemical conditions, Yakima River Basin, Washington, 1990: U.S. Geological Survey Water-Resources Investigations Report 96-4280, $94 \mathrm{p}$.

Darton, N.H., 1902, Preliminary list of deep borings in the United States, Part 1 (Alabama-Montana): U.S. Geological Survey Water-Supply and Irrigation Papers 57, 60 p.

Dion, N.P., and Lum, W.E., 1977, Municipal, industrial, and irrigation water use in Washington, 1975: U.S. Geological Survey Open-File Report 77-308, 34 p.

Drost, B.W., Whiteman, K.J., and Gonthier, J.B., 1990, The geologic framework of the Columbia Plateau regional aquifer system, Washington, Oregon, and Idaho: U.S. Geological Survey Water-Resources Investigations Report 87-4238, 10 p., 10 sheets.

Flaherty, N.M., 1975, The Yakima Basin and its water: Washington State University, Water Resources Center, Pullman, Wash., 29 p.

Fuhrer, G.J., McKenzie, S.W., Rinella, J.F., and Skach, K.A., 1997, Surface-water assessment of the Yakima River Basin in Washington: Analysis of major and minor elements in fine-grained-streambed sediment, 1987, with a section on Geology, by Gannett, M.W.: U.S. Geological Survey OpenFile Report 93-30, 226 p.

Glantz, M.H., 1982, Consequences and responsibilities in drought forecasting: The case of Yakima, 1977: Water Resources Research, v. 18, no. 1, p. 3-13.

Homer, Collin, Huang, Chengquan, Yang, Limin, Wylie Bruce, and Coan, Michael, 2004, Development of a 2001 National Landcover Database for the United States: Photogrammetric Engineering and Remote Sensing, v. 70, no. 7, p. 829-840. On-line on the World Wide Web, accessed October, 2004, at URL http://www.mrlc.gov/mrlc2k_product_desc.asp

Hurr, R.T., and Litke, D.W., 1989, Estimating pumping time and ground-water withdrawals using energy-consumption data: U.S. Geological Survey Water-Resources Investigations Report 89-4107, 27 p.

Jones, M.A., Vaccaro, J.J., and Watkins, A.M., 2006, Hydrogeologic framework of sedimentary deposits in six structural basins, Yakama River Basin, Washington: U.S. Geological Survey Scientific Investigations Report 20065116, 24 p., 7 pls. On-line on the World Wide Web, at URL http://pubs.water.usgs.gov/sir2006-5116

Kinnison, H.B., and Sceva, J.E., 1963, Effects of hydraulic and geologic factors on streamflow of the Yakima River Basin, Washington: U.S. Geological Survey Water-Supply Paper $1595,134 \mathrm{p}$. 
Kratz, M.R., 1978, Dilemmas, disruptions, but no disaster-drought in the Yakima basin, Washington, 1977: State Climatologist for Arizona Climatological Publications, Scientific Paper no. 3, 16 p.

Laird, L.B., and Walters, K.L., 1967, Municipal, industrial, and irrigation water use in Washington, 1965: U.S. Geological Survey Open-File Report, 13 p.

Lane, R.C., 2004, Estimated domestic, irrigation, and industrial water use in Washington, 2000: U.S. Geological Survey Scientific Investigations Report 2004-5015, 16 p.

Meyers, C.W., and Price, S.M., 1979, Geologic studies of the Columbia Plateau, a status report: Rockwell International, Rockwell Hanford Operations RHO-BWI-ST-4, 520 p.

Omernik, J.M., 1987, Ecoregions of the conterminous United States: Annals of the Association of American Geographers, v. 77 , no. 1 , p. 118-125.

Parker, G.G., Jr., 1971, Municipal, industrial, and irrigation water use in Washington, 1970: U.S. Geological Survey Open-File Report, 21 p.

Parker, G.L, and Storey, F.B, 1913, Water powers of the Cascade Range, Part III, Yakima River Basin: U.S. Geological Survey Water Supply Paper 369, 169 p., 18 pls.

Russell, I.C., 1897, A reconnaissance of southeastern Washington: U.S. Geological Survey Water-Supply Paper 4, 96 p.

Smith, G.O., 1901, Geology and water resources of a portion of Yakima County, Washington: U.S. Geological Survey Water-Supply and Irrigation Papers 55, 68 p.

Systems Operations Advisory Committee, 1999, Report on biologically based flows for the Yakima River basin: Report to The Secretary of the Interior, May 1999, Yakima, Wash., Executive Summary, 6 chap., 1 appendix.

Tri-County Water Resource Agency, 2003, Watershed plan document, accessed September, 2005 at URL http://www. co.yakima.wa.us/tricnty/
U.S. Census Bureau, 2004, Census 2000 TIGER/Line Data, accessed July 2004 at URL http://www.census.gov/

U.S. District Court, 1945, Consent decree in the District Court of the United States for the Eastern District of Washington, Southern Division: Civil action No. 21, Spokane, Wash.

Vaccaro, J.J., 1995, Changes in the hydrometeorological regime in the Pacific Northwest: Proceedings of the Twelfth Annual Pacific Climate Workshop, Asilomar, Cal., Technical Report 46 of the Interagency Ecological Program for the Sacramento-San Joaquin Estuary, p. 143.

Van Metre, Peter, and Seevers, Paul, 1991, Use of Landsat imagery to estimate ground-water pumpage for irrigation on the Columbia Plateau in Eastern Washington, 1985: U.S. Geological Survey Water-Resources Investigations Report 89-4157, 38 p.

Washington State Department of Ecology, 1998, Washington State water law, A Primer: WR-98-152, accessed October 2000, at http://www.ecy.wa.gov/pubs/98152.

Washington State Department of Health, 2001a, Water system design manual: Division of Environmental Health, Office of Drinking Water, accessed October, 2001 at URL http:// www.doh.wa.gov/ehp/dw/publications/design.htm

Washington State Department of Health, 2001b, Water system design manual: Division of Environmental Health, Office of Drinking Water, accessed October, 2001-May, 2003 at URL http://www.doh.wa.gov/ehp/dw/our_main_pages/data_ download.htm

Washington State Office of Financial Management, 2002, Population, accessed May, 2002 at URL http://www.ofm. wa.gov/pop 


\section{Appendix 1. List of Acronyms Used In Report}

\begin{tabular}{|c|c|}
\hline \multicolumn{2}{|r|}{ Agencies: } \\
\hline $\mathrm{DOH}$ & Washington State Department of Health \\
\hline DOA & Washington State Department of Agriculture \\
\hline WaDOE & Washington State Department of Ecology \\
\hline Reclamation & Bureau of Reclamation \\
\hline USGS & U.S. Geological Survey \\
\hline TCWRA & Tri-County Watershed Resource Agency \\
\hline \multicolumn{2}{|r|}{ Terms: } \\
\hline WRIA & Washington State Water Resource Inventory Area \\
\hline TWSA & $\begin{array}{l}\text { Current available storage in the reservoirs, estimates } \\
\text { of unregulated flow, and other sources that are } \\
\text { principally return flows }\end{array}$ \\
\hline TRS & Township, range, and section \\
\hline PWS & Public water supply \\
\hline PCC & Power-consumption coefficient \\
\hline \multicolumn{2}{|r|}{ Water-Rights Terms: } \\
\hline WRTS & $\begin{array}{l}\text { WaDOE's digital water-rights database (Water Rights } \\
\text { Tracking System) }\end{array}$ \\
\hline Control ID & Water-right identification number (in WRTS) \\
\hline PRU & Purpose of use (in WRTS) \\
\hline POW & Point/s of withdrawal (in WRTS) \\
\hline POU & Place of use (in WRTS) \\
\hline
\end{tabular}

Water-Right PRUs Listed in WRTS:

CI Commercial and Industrial Manufacturing (includes food processing and packaging, sand and gravel processing, asphalt plant, metal processing and manufacturing, pulp and paper manufacturing, aquatic plant culture, petroleum refining, car washes, and laundries)

$\mathrm{CO} \quad$ Cooling for industrial purposes

DG Domestic General (use of water for all domestic uses not specifically defined in the water right record or not defined by the other specific domestic use categories. Includes sewage treatment, farm supply, and laboratory use)

DM Domestic Multiple (more than one dwelling, i.e. motels, trailer courts, campgrounds, parks, schools, port districts, public utility districts, diking and drainage districts, water districts, reclamation districts, and counties, none of which are under municipal control)

\begin{tabular}{|c|c|}
\hline \multicolumn{2}{|r|}{ Water-Right PRUs Listed in WRTS:-Continued } \\
\hline$\overline{\mathrm{DS}}$ & $\begin{array}{l}\text { Domestic Single (one dwelling with lawn and garden, } \\
\text { up to one-half acre) }\end{array}$ \\
\hline DY & Dairy \\
\hline EN & $\begin{array}{l}\text { Environmental Quality (includes pollution control, } \\
\text { dust control, flood control, or any water use } \\
\text { which improves or maintains the quality of the } \\
\text { environment) }\end{array}$ \\
\hline FP & $\begin{array}{l}\text { Frost Protection (frost protection other than } \\
\text { cranberries) }\end{array}$ \\
\hline FR & $\begin{array}{l}\text { Fire Protection (includes sprinkling log storage } \\
\text { facilities) }\end{array}$ \\
\hline FS & $\begin{array}{l}\text { Fish Propagation (includes water service to ponds, } \\
\text { reservoirs, hatcheries, and all other facilities } \\
\text { involved in the overall purpose of fish propagation) }\end{array}$ \\
\hline $\mathrm{HE}$ & $\begin{array}{l}\text { Heat Exchange (use of such equipment as heat pumps, } \\
\text { refrigeration equipment, and other cooling devices) }\end{array}$ \\
\hline HW & Highway (maintenance and construction) \\
\hline IR & $\begin{array}{l}\text { Irrigation (includes cranberry farming, lawn/garden } \\
\text { watering with definite acreage, golf courses, } \\
\text { greenhouses, etc.) }\end{array}$ \\
\hline MI & $\begin{array}{l}\text { Mining (includes washing coal, dredge mining, and } \\
\text { hydraulic mining) }\end{array}$ \\
\hline MU & $\begin{array}{l}\text { Domestic Municipal (serves general domestic, } \\
\text { commercial, and industrial needs of an incorporated } \\
\text { municipality, i.e. cities, towns, and outlying areas) }\end{array}$ \\
\hline $\mathrm{PO}$ & $\begin{array}{l}\text { Power (includes hydro-electric, hydraulic ram, and } \\
\text { thermo-electric) }\end{array}$ \\
\hline RE & $\begin{array}{l}\text { Recreation and Beautification (includes beautifying } \\
\text { private and public grounds and supplying water to } \\
\text { swimming pools, boating ponds, etc.) }\end{array}$ \\
\hline RW & $\begin{array}{l}\text { Railway (use of water to serve railway equipment and } \\
\text { facilities) }\end{array}$ \\
\hline ST & $\begin{array}{l}\text { Stock Watering (includes domestic uses of water } \\
\text { for dairy/cattle farms, game bird farming, poultry } \\
\text { farming, and fur-bearing animal farming) }\end{array}$ \\
\hline WL & $\begin{array}{l}\text { Wildlife Propagation (includes water to service non- } \\
\text { domesticated animals such as birds, game and non- } \\
\text { game species) }\end{array}$ \\
\hline
\end{tabular}


This page intentionally left blank 
Manuscript approved for publication, August 12, 2006

Prepared by the USGS Publishing Network,

Publishing Service Center, Tacoma, Washington

Bill Gibbs

Debra Grillo

Donita Parker

Bobbie Jo Richey

Sharon Wahlstrom

For more information concerning the research in this report, contact the Director, Washington Water Science Center

U.S. Geological Survey, 934 Broadway - Suite 300

Tacoma, Washington 98402

http://wa.water.usgs.gov 
䍐

产

으

옥

言

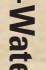

0

홍

홍

के

产

ํํำ

త్ర

品

I.

를.

is

क्ञ

$\sum$

墨.

홍

$\overrightarrow{0}$

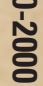

古 $\frac{\mathrm{s}}{\mathrm{D}}$

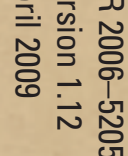

